\title{
An American "Duchess" in Disguise: John Singleton Copley's Turquerie Portrait of Margaret Kemble Gage
}

\author{
Elizabeth Rininger \\ West Virginia University
}

Follow this and additional works at: https://researchrepository.wvu.edu/etd

\section{Recommended Citation}

Rininger, Elizabeth, "An American "Duchess" in Disguise: John Singleton Copley's Turquerie Portrait of Margaret Kemble Gage" (2011). Graduate Theses, Dissertations, and Problem Reports. 4773.

https://researchrepository.wvu.edu/etd/4773

This Thesis is protected by copyright and/or related rights. It has been brought to you by the The Research Repository @ WVU with permission from the rights-holder(s). You are free to use this Thesis in any way that is permitted by the copyright and related rights legislation that applies to your use. For other uses you must obtain permission from the rights-holder(s) directly, unless additional rights are indicated by a Creative Commons license in the record and/ or on the work itself. This Thesis has been accepted for inclusion in WVU Graduate Theses, Dissertations, and Problem Reports collection by an authorized administrator of The Research Repository @ WVU. For more information, please contact researchrepository@mail.wvu.edu. 


\title{
An American "Duchess" in Disguise:
}

\section{John Singleton Copley's Turquerie Portrait of Margaret Kemble Gage}

\author{
Elizabeth Rininger
}

\author{
Thesis submitted to the \\ College of Creative Arts \\ at West Virginia University \\ in partial fulfillment of the requirements \\ for the degree \\ of
}

Master of Arts

in Art History

Dr. Rhonda Reymond, Chair

Dr. Janet Snyder

Prof. Kristina Olson

\author{
Division of Art and Design \\ Morgantown, West Virginia \\ 2011
}

Keywords: John Singleton Copley, Orientalism, Margaret Kemble Gage, Colonial America Copyright 2011 Elizabeth Rininger 


\section{ABSTRACT \\ An American "Duchess" in Disguise: John Singleton Copley's Turquerie Portrait of Margaret Kemble Gage}

\section{Elizabeth Rininger}

A number of portraits that John Singleton Copley painted in the years prior to the American Revolution show women clad in turquerie. Traditionally, art historians have explained the appearance of this fashion as provincial colonials copying fashions from their parent country. The appeal of the fashion was strong; however, the political, social, and sexual connotations complicate this explanation for the sitters' choice of dress. While the purpose here is not to disprove the explanation of fashion-consciousness, it is to read these portraits from the perspective of the colonized rather than the colonizer. It is an attempt to decode an appropriated imperial fashion and to acknowledge the potentially subversive character of the portraits. Positioned as a sample of the masterful union of the native and the imagined, the perceived and the conjured, the unique and the culturally prescribed, Margaret Gage (1771) provides a significant opportunity to interrogate seemingly irreconcilable social, political, and artistic elements in order to better understand Copley's ways of seeing and his working methods, as well as, his subject's personal beliefs. Margaret Gage is an expression of both colonial and national identity at a time when those identities were very much contested. 


\section{CONTENTS}

ACKNOWLEDGEMENTS ...........................................................

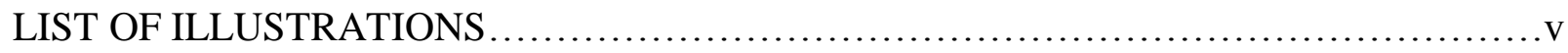

INTRODUCTION: A Curious Group of New England Women................................

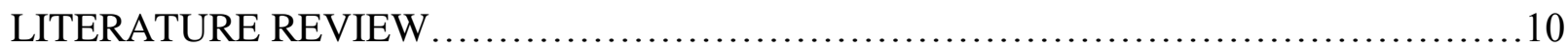

CHAPTER ONE: “The Duchess” and an Immigrant's Son.................................14

CHAPTER TWO: A Young Artist with Limited Reputation................................18

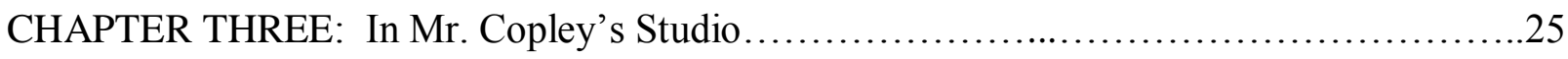

CHAPTER FOUR: The First American Realist............................................ 30

CHAPTER FIVE: Turkish Inspirations...................................................

CHAPTER SIX: A Love of All Things British............................................46

CHAPTER SEVEN: Cloth and Clothing in Colonial America...............................50

CHAPTER EIGHT: Pasted Heads and Body Work........................................5 54

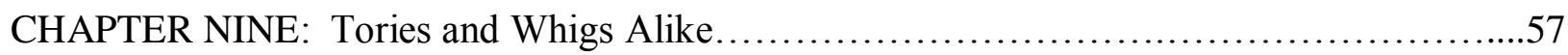

CHAPTER TEN: To Break Away From Rigid Confinements..................................61

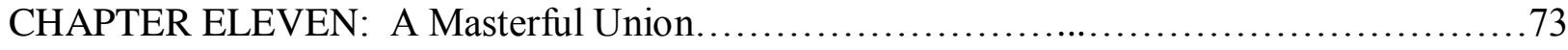

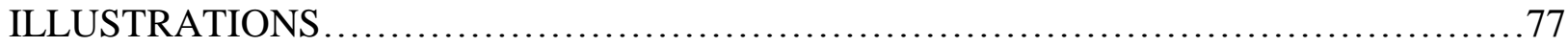

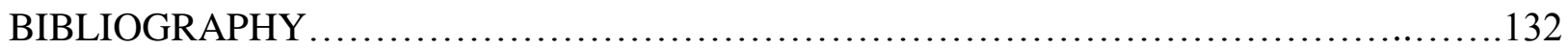




\section{ACKNOWLEDGEMENTS}

I wish to thank my graduate committee for their advice, time, encouragement, and constant support. Without your guidance and teachings, this paper would never have been written.

I would also like to thank my family, especially my brothers and sister, for their love and patience. A very special thank you to my husband Todd, and to my parents, Greg and Judy, for always motivating me and expressing their never-ending love which made completing my thesis possible. 


\section{LIST OF ILLUSTRATIONS}

Figure

Page

1 John Singleton Copley, Mary Turner Sargent (Mrs. Daniel Sargent), 1763. Oil on canvas, Fine Arts Museums of San Francisco, de Young Museum.

2 John Singleton Copley, Francis Atkinson (Mrs. Theodore Atkinson, Jr.), 1765. Oil on canvas, Private Collection.

3 John Singleton Copley, Elizabeth Lewis Goldthwait (Mrs. Ezekiel Goldthwait), 1771. Oil on canvas, The Museum of Fine Arts, Boston............................................79

4 John Singleton Copley, Margaret Kemble Gage (Mrs. Thomas Gage), 1771. Oil on canvas, The Timken Museum of Art, San Diego.........................................8 80

5 Peter Pelham, Cotton Mather, 1727. Oil on canvas, American Antiquarian Society......81

6 Peter Pelham, Cottonus Matherus, 1727. Mezzotint, American Antiquarian Society.....81

7 John Singleton Copley, Reverend William Welsteed, 1753. Mezzotint, Museum of Fine

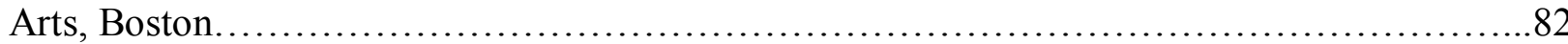

8 Peter Pelham after Jan Van der Vaart, Reverend William Cooper, 1724. Mezzotint, Museum of Fine Arts Boston............................................................82

9 John Singleton Copley, The Return of Neptune, 1754. Oil on canvas, 27 1/2 x 44 1/2 in, The Metropolitan Museum of Art .................................................... 83

10 Simon François Ravenet after Andrea Casali, The Return of Neptune, 1749. Mezzotint, The Metropolitan Museum of Art...................................................83

11 John Singleton Copley, Watson and the Shark, 1778. Oil on canvas, 72 1/4 x 90 3/8 in, Museum of Fine Arts, Boston........................................................ 84

12 John Singleton Copley, Defeat of the Floating Batteries at Gibraltar (The Siege and Relief of Gibraltar), 1782. Oil on canvas, Guildhall Art Gallery, London......................85

13 John Singleton Copley, Mars, Venus, and Vulcan, 1754. Oil on canvas, Private Collection.

14 John Singleton Copley, Plate II, Book of Anatomical Drawings, 1756. The British

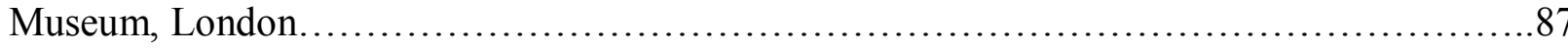

15 John Singleton Copley, Plate VIII, Book of Anatomical Drawings, 1756. The British Museum, London............................................................. 87 
16 John Singleton Copley, Right Measured Study of the Venus Medici, 1756. The British

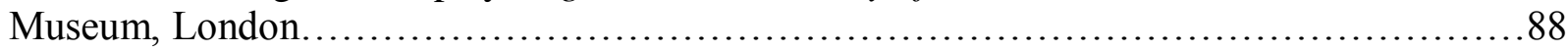

17 John Singleton Copley, The Gore Children, 1755. Oil on canvas, Winterthur.........89

18 John Smibert, Jane Clark, 1732. Oil on canvas, Massachusetts Historical Society.....90

19 Robert Feke, James Bowdoin II, 1748. Oil on canvas, Bowdoin College Museum of

Art........................................................................................

20 John Greenwood, Greenwood-Lee Family, 1747. Oil on canvas, Museum of Fine Arts,

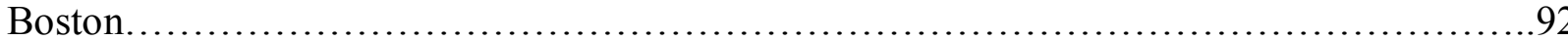

21 Robert Feke, The Isaac Royall Family, 1741. Oil on canvas, Size not given, Harvard Law School, Caspersen Room.............................................................. 93

22 Joseph Blackburn, Mary Sylvester, 1754. Oil on canvas, The Metropolitan Museum of

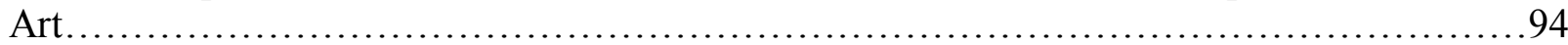

23 John Singleton Copley, Ann Tyng Smelt (Mrs. Thomas Smelt), 1756. Oil on canvas, Museum of Fine Arts, Boston................................................................ 95

24 John Singleton Copley, Sarah Boylston (Mrs. Thomas Boylston), 1765-66. Oil on canvas, Fogg Art Museum, Harvard University, Boston........................................... 96

25 John Singleton Copley, Elizabeth Smith (Mrs. Isaac Smith), 1769. Oil on canvas, Yale University Art Gallery.................................................................. 97

26 John Singleton Copley, Portrait of a Lady, 1771. Oil on canvas, Los Angeles County

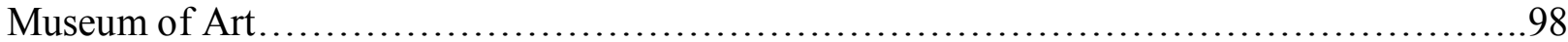

27 John Singleton Copley, General Thomas Gage, 1768. Oil on canvas, Yale Centre for

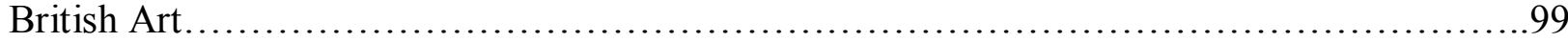

28 John Singleton Copley, Reverend Myles Cooper, 1768-1769. Oil on canvas, Columbia University, New York................................................................... 100

29 Ralph Earl, Mrs. Charles Jeffery Smith, 1794. Oil on canvas, New York Historical Society. . . .

30 Carle van Loo, The Sultana Drinking Coffee, 1754. Oil on canvas, Hermitage Museum,

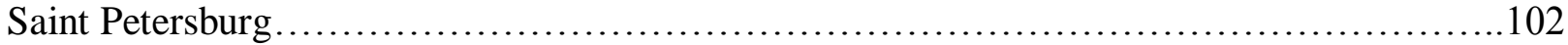

31 Jean-Étienne Liotard, Mary Gunning, Countess of Coventry, 1749. Pastel on vellum,

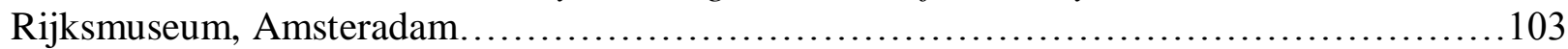


32 Jean-Étienne Liotard, Marie Adelaide of France dressed in Turkish Costume, 1753. Oil on canvas, Uffizi Gallery, Florence..................................................... 104

33 Angelica Kauffmann, Penelope Weeping Over the Bow of Ulysses, 1779. Oil on copper, Wolverhampton Art Gallery, Wolverhampton........................................ 105

34 John Singleton Copley, Martha Swett Lee (Mrs. Jeremiah Lee), 1769. Oil on canvas, Wadsworth Atheneum, Connecticut..................................................... 106

35 John Singleton Copley, Mercy Otis Warren, 1779. Oil on canvas, 1763, Boston Museum of Fine Arts, Boston................................................................. 107

36 John Singleton Copley, Catherine Sargent, 1764. Oil on canvas, Private Collection...108

37 John Singleton Copley, Hannah Hill Quincy (Mrs. Samuel Quincy), 1761. Oil on canvas, Museum of Fine Arts, Boston. 109

38 John Singleton Copley, Judith Sargent (Mrs. John Stevens, later Mrs. John Murray), 1770-1771. Oil on canvas, Terra Foundation for American Art, Chicago.....................110

39 John Sngleton Copley, Elizabeth Murray Smith (Mrs. James Smith, later Mrs. John Inman), 1769. Oil on canvas, Museum of Fine Arts, Boston.

40 John Singleton Copley, Catherine Greene (Mrs. John Greene), 1769. Oil on canvas, Cleveland Museum of Art........................................................... 112

41 John Singleton Copley, Rebecca Boylston Gill (Mrs. Moses Gill), 1773. Oil on canvas, Rhode Island School of Design Museum of Art......................................113

42 John Singleton Copley, Elizabeth Ross (later Mrs. William Tyng), 1766. Oil on canvas, Museum of Fine Arts, Boston.......................................................... 114

43 John Singleton Copley, Mercy Greenleaf Scoally (Mrs. John Scoally), 1763. Oil on canvas, Baltimore Museum of Art.............................................. 115

44 John Singleton Copley, Mercy Greenleaf Scoally (Mrs. John Scoally), 1763. Oil on canvas, Baltimore Museum of Art .............................................. 116

45 John Singleton Copley, Abigail Pickman Gardiner (Mrs. Sylvester Gardiner), 1772. Oil on canvas, Brooklyn Museum of Art.............................................117

46 John Singleton Copley, Abigail Smith Babcock (Mrs. Adam Babcock), 1774. Oil on canvas, National Gallery of Art, Washington, D.C ................................. 118

47 Caroline Watson after Sir Godfrey Kneller, Lady Mary Wortley Montagu, 1719-20.

Engraving, The marquess of Bute, Rothesay..................................... 119 


\section{INTRODUCTION \\ A Curious Group of New England Women}

In her 1763 portrait painted by John Singleton Copley (1738-1815), Mary Sargent stands confidently in an elaborate and sumptuous blue dress while delicately holding a small shell under a cascade of water (fig. 1). ${ }^{1}$ In a portrait painting of Francis Atkinson from 1765, while the sitter's gaze confidently meets the viewer's, a small flying squirrel on a tiny gold chain sits on a glossy tabletop. ${ }^{2}$ Atkinson's full skirt and deep blue robe billow around her in waves of shiny satin, accentuating her slender figure. The chestnut brown silk sash arranged across her gown is perhaps a suggestion of the familiar accessory of royal dress (fig. 2). Elizabeth Goldthwait, in her 1771 portrait, sits in a matronly state at a polished wood table, a small smile playing around the corners of her mouth. As she reaches for a piece of fruit, an emblematic reference to the thirteen children she had borne, a cuff of fine lace falls across her arm. ${ }^{3}$ Her full skirt of rich, chocolate brown silk rivals the table in luster and sheen (fig. 3). Elegantly dressed and

\footnotetext{
${ }^{1}$ For the birthday of John Singleton Copley see Henry W. Foote, "When was John Singleton Copley Born?," The New England Quarterly 10, no. 1 (March 1973): 111-120. Foote comes to the conclusion, after studying various public documents and personal letters by member s of the Copley family, that the most accurate date for Copley's date of birth is July 3, 1738. For information about the symbol of the scallop shell see S. Peter Dance, Shell Collecting (Berkeley: University of California Press, 1966), 53-131. The scallop shell Mary Sargent holds was an omnipresent artifact of eighteenth-century Boston. Shells were bought, collected, coveted, and displayed as scientific exemplars in the homes of many wealthy Americans and Europeans. Perhaps most important, however, shells had a long pedigree among artists as accoutrements associated with Neptune, Venus, and the sea. They were possibly the most popular motif used on decorative objects of the eighteenth-century eastern seaboard. See Ian H. Cox, ed., The Scallop (London: Shell Transport, 1957). The shell in Mary Sargent's portrait becomes a symbol of her culture and wealth.

${ }^{2}$ According to Anderson in Creatures of Empire: How Domestic Animals Transformed Early America (New York: Oxford University Press, 2004), colonists applied their familiar ideas of dominance and domestication to animals in the unfamiliar and wild new world. This type of relationship was considered natural and divinely sanctioned. Taming its wild animals was one more way colonists saw they could take possession of the new world. The taming of wild animals, such as flying squirrels, became a sign of high social status because only the wealthy had the time and resources to care for and train pets, or "favorites" as was the vernacular. Furthermore, these animals were symbols of the owner's good breeding because only a domesticated person could domesticate a wild animal. The obedient and seemingly gentle flying squirrel in Atkinson's portrait serves as evidence of her gentility.

${ }^{3}$ Museum of Fine Arts, Boston, "Mrs. Ezekiel Goldthwait (Elizabeth Lewis)," http://mfa.org/collections/search_art.asp?recview=true\&id=32756\&coll_keywords=Elizabeth+Goldthwait\&coll_acc ession $=\&$ coll_name $=\&$ coll_artist $=\&$ coll_place $=\&$ coll_medium $=\&$ coll_culture $=\&$ coll_classification $=\&$ coll_credit $=$ $\&$ coll_provenance $=\&$ coll_location $=\&$ coll_has_images $=\&$ coll_on_view $=\&$ coll_sort $=0 \&$ coll_sort_order $=0 \&$ coll_vie w=0\&coll_package=0\&coll_start=1 (accessed May1, 2010).
} 
possessing attributes of feminine grace, accomplishment, and fertility, these three women resemble many in Copley's portrait oeuvre. ${ }^{4}$ They conform to traditional expectations of what affluent colonial American women would wear, how they would carry themselves, and what their interests would be.

American colonial portrait paintings are social documents, giving evidence of the sitter's social position, wealth, and good breeding. The sitters present themselves and their possessions with self-consciousness: dress, posture, and props would have been carefully selected to communicate status and accomplishments. The social and economic positioning of the sitter was being recorded for friends, colleagues, and future generations. However, it is also possible to see colonial American painted portraits as documents of other, more complex, private ideals. Those other ideals straddle the public and private spheres of colonial life. They reflect not just social standing, but personal beliefs. For example, the assumption of prescribed gender roles and the assertion of wealth might be paired with a political testament, or a religious declaration.

Amongst Copley's portraits of genteel young ladies, proper matrons, and dignified gentleman there exists a curious group of New England women. They wear loose, flowing gowns with low necklines and full sleeves. Some have donned ermine-trimmed robes. Others have chosen to wear tasseled silk turbans. Strings of pearls decorate their hair. The appearance of this exotic costume in these women's portraits challenges the traditional definition of colonial American portraiture. Instead of self-consciously presenting themselves as refined objects of colonial gentility, these women, with their turbans, pearls, and robes, seem to refute social protocol. The appeal of the fashion was strong, but the political, social, and sexual connotations of the costume complicate that explanation for the sitters' choice of dress. By looking with

\footnotetext{
${ }^{4}$ Museum titles for the paintings presented in this paper vary. In the interest of consistency, I refer to the women by their given first names and married last names.
} 
focused intensity at one work in this exotic faction of Copley portraits in as broad a spectrum of social evidence as possible, an occasion arises to explore Copley's artistic practice and his role in expressing his patrons' public and private ideals. Positioned as a sample of the masterful union of the native and the imagined, the perceived and the conjured, the unique and the culturally prescribed, Margaret Gage (1771) provides a significant opportunity to interrogate seemingly irreconcilable social, political, and artistic elements in order to better understand Copley's ways of seeing and his working methods, as well as, his subject's personal beliefs and the underlying historical social systems this work expressed (fig. 5).

The differences between the exotic portraits, like Margaret Gage, and their more typical counterparts become clear in a comparison of two Copley portraits. Mary Sargent slightly holds the fold of her dress in her left hand with studied nonchalance (fig. 1). Her carefully assumed, stiff posture is a testament to her good breeding. She has learned the rules of correct posture; etiquette as well as her tightly laced corset keeps her back perfectly straight. ${ }^{5}$ Blue silk closely wraps her torso. Shiny silver lace criss-crosses her bodice and her full skirt. A white collar with a pink bow is accentuated by the tiny pink flowers in her hair. Just as she presents the shell as an object of beauty and refinement, so she presents herself.

In contrast to Sargent's clear awareness of the viewer, which is apparent in her perfect posture and meticulous dress, as well as a public, outdoor setting, Margaret Gage is lost in a private daydream (fig. 4). She lounges on a deep blue, camel-back couch in an indoor, private

\footnotetext{
${ }^{5}$ Many colonial women manipulated their figures through the use of corsets. Constructed of whalebone, horn, or other stiff materials, corsets modeled the eighteenth-century woman's torso into a compressed, cone-shaped figure that narrowed the waist and flattened the bust. The widespread use of corsets among middle- and upper-class women in colonial America might give the impression that they were preoccupied with maintaining a slim figure. However, the ideal female form in the eighteenth century was strong and shapely, but equally important was excellent posture. The way a woman carried herself was a sign of health, class, and self-discipline. A corset was indispensable for maintaining the faultless posture valued by early Americans. For more on corsets in colonial America see Dorothy A. Mays, Women in Early America: Struggle, Survival, and Freedom in a New World (Santa Barbara, ABC-CLIO, Inc., 2004): 49-51.
} 
space, her head is supported by one hand and the other is casually draped in the folds of her skirt. Her gaze is unfocused and distant. She appears to wear no corset, and her soft auburn hair, also unconstrained, tumbles over her right shoulder. Her shimmering, salmon-color dress, trimmed in gold, opens in the front to reveal a white underskirt. The wide hanging sleeves of the dress partly conceal the full sleeves of her chemise, which are tied with strands of pearls. A blue and gold sash compliments her blue and gold tasseled turban. ${ }^{6}$ Although her costume and posture were no doubt just as carefully chosen as Sargent's, Gage's seemingly casual pose and apparent disregard of the viewer suggest a complete lack of self-consciousness. In both portraits, dress and posture collaborate, creating an impression of studied grace and wealth in one, and a mood of dreamy sensuality and exoticism in the other.

\footnotetext{
${ }^{6}$ For a discussion on the characteristics of turquerie fashions see pages 32-35.
} 


\section{Literature Review}

Because of the complex nature of this research, the literature review is divided into two sections. The first section discusses the research and writings of art historians which were important for gaining an understanding of Copley, colonial American portraiture, as well as clothing and dressing practices in the eighteenth-century. These include: two works by Aileen Ribeiro The Art of Dress: Fashion in England and France, 1750-1820 (1995) and Dress in Eighteenthcentury Europe (2002), Barbara Novak's American Painting of the Nineteenth Century: Realism, Idealism, and the American Experience (1979), Wayne Craven's Colonial American Portraiture: The Economic, Religious, Social, Cultural, Philosophical, Scientific, and Aesthetic Foundations (1986), Timothy Breen's article “"The Meaning of Likeness': American Portrait Painting in an Eighteenth-Century Consumer Society" (1990), and Paul Staiti’s essay "Accounting for Copley" (1996). The second section focuses on the works of scholars who address the theory of orientalism and the "other," beginning with Edward Said's Orientalism (1978), Lisa Lowe's Critical Terrains: French and British Orientalisms (1991), and Perrin Stein's article “Amédée van Loo’s Costume Turc: The French Sultana” (1996). Each of these writer's theories were important to the argument of this paper.

The artist: John Singleton Copley and Dress in the Eighteenth-century

Several American art historians have seen in Copley's works the beginning of a threecentury tradition of realism in American painting. Barbara Novak, in her book American Painting of the Nineteenth Century: Realism, Idealism, and the American Experience (1979), specifically credits Copley with starting the tradition of realism in America. ${ }^{7}$ Novak praises

\footnotetext{
${ }^{7}$ Barbara Novak, American Painting of the Nineteenth Century: Realism, Idealism, and the American Experience (New York: Harper and Row, 1979), 3.
} 
Copley's self-taught artistic accomplishments while admiring and sympathizing with the persevering artist and his naive patrons. In his book Colonial American Portraiture: The Economic, Religious, Social, Cultural, Philosophical, Scientific, and Aesthetic Foundations (1986), Wayne Craven examines the art of Copley, not only from the perspective of the artist's talent and genius, but also as a product of the complex expression of society and individuality. Craven sees Copley's paintings as a marriage of the skills, empirical practices, and career objectives of the self-trained artist and his provincial patrons. ${ }^{8}$

While these scholars emphasize Copley's realistic painting style, an opposing view presented by historians such as Timothy Breen in his article “"The Meaning of Likeness': American Portrait Painting in an Eighteenth-Century Consumer Society" (1990), and Paul Staiti in his essay "Accounting for Copley" (1996), contend that Copley was not a realist. They argue that neither the faces nor the material culture with which he provides his sitters in his portraits are records of optical experience. Copley was, they propose, constructing dramas designed to compliment his provincial clientele. They downplay the realism in Copley's works, his replication of empirical vision, and emphasize instead the artist's ability to fictionalize under the façade of authenticity, and focus on Copley's embrace of artifice, imitation, and convention. ${ }^{9}$

Although Novak and Craven, Breen and Staiti appear to place themselves on opposite sides of the discussion, their theories create a rich middle-ground on which the argument of this paper is based. All of Copley's portrait paintings have their foundations in the exact replication of certain aspects of the three-dimensional world before the painter. At the same time, all

\footnotetext{
${ }^{8}$ Wayne Craven, Colonial American Portraiture: The Economic, Religious, Social, Cultural, Philosophical, Scientific, and Aesthetic Foundations (Cambridge: Cambridge University Press, 1986), 9, 111, 126, 259, 304, 318-350.

${ }^{9}$ Paul Staiti, "Accounting for Copley," in Carrie Rebora et al., eds., John Singleton Copley in America (New York: Metropolitian Museum of Art, 1996): 25,28,29,32,33,37,40; T.H. Breen, "The Meaning of Likeness': American Portrait Painting in an Eighteenth-Century Consumer Society," Word and Image 6, no. 4 (OctoberDecember 1990): 35-50.
} 
portraits are, to some extent, based on convention, artifice, and fiction, and all respond to the parameters of their culture in terms of dress, body type, deportment, accoutrements, and even facial expression. In this way, Copley's portrait of Margaret Kemble Gage (fig. 4) is an important example of the blending of the artist's complex way of seeing and representing the world, while also expressing the personal values and beliefs of the sitter.

In her work, The Art of Dress: Fashion in England and France, 1750-1820 (1995), costume historian Aileen Ribeiro analyzes the clothing worn by the middle and upper classes throughout England and France in the eighteenth century and discusses what fashion meant in terms of social definition and identity in Europe. By examining artworks from the period, Ribeiro sees fashion as a vehicle for the expression of social and political ideals by individuals in a complex and changing society. Furthering the discussion begun in The Art of Dress, Ribeiro's book, Dress in Eighteenth-century Europe (2002), examines different ways that England and France appropriated the dress of foreign cultures during the eighteenth century, not only for fashion, but for political and social reasons as well. Most important for this research, Ribeiro chronicles the appearance and evolution of Turkish-inspired costumes and clothing in French and English society.

\section{$\underline{\text { Orientalism }}$}

In his highly regarded and influential text, Orientalism (1978), Edward Said directly challenged what Euro-American scholars traditionally referred to as "Orientalism." Orientalism is an entrenched structure of thought, a pattern of making certain generalizations about the part of the world known as the East. As Said explains, "Orientalism was ultimately a political vision of reality whose structure promoted the difference between the familiar [Europe, West, "us"] and 
the strange [the Orient, the East, "them"]."10 Said's definition of orientalism was an important basis for this paper. He defines orientalism as "a certain will or intention to understand, in some cases to control, manipulate, even to incorporate, what is a manifestly different world."11 $\mathrm{He}$ emphasizes that orientalism's ultimate concern is with "the idea of Europe" and the identification of Europe as different from and superior to all non-European nations. ${ }^{12}$ Said's research on the discourse between East and West illustrates how an "intention to understand" can lead to misinformation, sufficiently repeated over time, becoming fact. Certainly the physical costumes the women in Copley's portraits wear are examples of misinformation becoming fact. However, the importance of this research is not how the fashion was misinterpreted, but that it was; and what this (mis-) interpretation may have meant to the women in the costume.

While Said's conclusions may have applied to most Western travellers to the orient, they hardly ever applied to female travelers. Lisa Lowe in Critical Terrains: French and British Orientalisms (1991), shows that Lady Mary Wortly Montagu in her Turkish Embassy Letters (1763), challenged many of the preconceptions concerning the lives of Turkish women, held by many Western male travellers to Turkey at the time. Lowe also discusses in her book a "plurality and mutability" of the orientalist discourse that allows for various readings of the situation depending on who is doing the reading. ${ }^{13}$ In this paper this mutable and transformative process is applied to the analysis of turquerie in Margaret Gage's portrait.

Art historian Perrin Stein, focusing on the eighteenth century, furthers the discussion begun by Said and Lowe by suggesting that the interest in the exotic "other" and territorial expansion that characterized later orientalism "took a back seat in the eighteenth century to

\footnotetext{
${ }^{10}$ Edward W. Said, Orientalism (New York: Vintage Books, 1979), 43.

${ }^{11}$ Ibid., 12.

${ }^{12}$ Ibid., 7.

${ }^{13}$ Lowe, Critical Terrains: French and British Orientalisms (Ithaca: Cornell University Press, 1991), 32.
} 
allegorical functions built around gender and class close to home."14 In her 1996 Art Bulletin piece, “Amédée Van Loo’s Costume Turc: The French Sultana,” Stein points out that eighteenth-century Europeans used the harem to symbolize the ability of the patriarchal order to control women. ${ }^{15}$ The issues of gender and power that surround turquerie in eighteenth-century Europe are similarly reflected in Copley's portraits done in the American colonies. In Europe where the patriarchal laws of coverture had been an omnipresent fact in the lives of women for thousands of years; in America extraordinary conditions in the earliest days of colonization had required that coverture laws be ignored. ${ }^{16}$ However, by the time Copley painted his turquerie portraits, social conditions had changed and the old laws of coverture, with their roots strongly planted in England, had gradually eroded the liberties that America's earliest women had experienced. Therefore, as this paper will argue, in America turquerie was more likely used as a symbol of protest, disguised in a costume of submission, against the western laws and social structures that annulled the liberties America's women once experienced.

\footnotetext{
${ }^{14}$ Perrin Stein, “Amédée Van Loo’s Costume Turc: The French Sultana," Art Bulletin 78 (September, 1996): 417.

${ }^{15}$ Ibid., 432.

${ }^{16}$ For a discussion on coverture in early colonial America see pages 61-64.
} 


\section{Chapter 1 \\ "The Duchess" and An Immigrant's Son}

Copley's subject was a colonial heiress. Margaret Kemble Gage was a member of one of the most influential families in colonial American society. Her father was Peter Kemble, president of the Council of New Jersey and her brother was Stephen Kemble, captain of the British Army's Sixtieth Regiment during the American Revoluion. Margaret Kemble was raised in a Georgian mansion furnished in the style of an English manor house situated on a large tract of land in what is today Morris County, New Jersey. ${ }^{17}$ In 1758, she married Thomas Gage while he was serving in the French and Indian War, five years prior to his appointment as commanderin-chief of the British forces in North America. ${ }^{18}$

Little information is known about Margaret Kemble before she became Mrs. Thomas Gage. Historian John Richard Alden's account of General Gage in America (1969) refers to her as "the proud beauty of a town noted for the charm of its women." ${ }^{19}$ As the wife of a military commander, Mrs. Gage's life was full of demands, the breaking up and setting up of households when moves were required, the entertaining of guests, and the birth of five daughters and six sons. ${ }^{20}$ Despite her numerous duties and confinements, Margaret Gage gave teas and dinner parties, regularly attended the theater, balls, and horse races; all while juggling the household accounts and children. ${ }^{21}$ General Gage's fellow officers referred to his wife as "the Duchess."22

\footnotetext{
${ }^{17}$ Richard Reilly, "Margaret 200 years later," San Diego Union-Tribune, July 1, 1984, E-1.

${ }^{18}$ Richard Alden, General Gage in American: Being Principally a History of His Role in the American Revolution (California: Greenwood Press, 1969), 96.

${ }^{19}$ Ibid., 98.

${ }^{20}$ Ibid., 97

${ }^{21}$ Janet Bogden, "Care or Cure? Childbirth Practices in Nineteenth Century America," Feminist Studies, no. 2 (June 1978): 93. Bogden refers to confinement being an integral stage in pregnancy even into the nineteenth century. For Margaret Gage's role as a General's wife see John Richard Alden, General Gage in America.

${ }^{22}$ Richard Reilly, "Margaret 200 years later," E-1.
} 
Her intellect and beauty made her "a belle in social circles throughout the middle colonies." 23 Although Mrs. Gage was very popular, or perhaps because she was so popular, she was accused by members of her own social class of being overly proud, of using her husband's position to secure appointments for relatives, and especially of dominating the New York City society. ${ }^{24}$

In the years prior to the American Revolutionary War, New York society was in a state of tumult and Margaret Gage made no secret of the deep distress she felt about the growing rift between Britain and America. She once told a close friend of her family that "she hoped her husband would never be the instrument of sacrificing the lives of her countrymen." 25 She confided in another friend that her feelings were those spoken by Lady Blanche in Shakespeare's King John:

The sun's o'ercast with blood; fair day, adieu!

Which is the side that I must go withal?

I am with both: each army hath a hand;

And in their rage, I having hold of both,

They whirl asunder and dismember me. ${ }^{26}$

Margaret Gage's loyalties came into question on both sides of the Revolution. There is strong circumstantial evidence that she passed military secrets to the colonial militia. Historians such as David Hackett Fischer have controversially suggested that she was sympathetic to the colonial cause and may have supplied the rebels with military information. In particular, she supposedly warned Joseph Warren on April 18, 1775 that her husband's troops planned to raid armories at Lexington and Concord, leading to Paul Revere's famous Midnight Ride. According to Fischer,

We shall never know with certainty the name of Doctor Warren's informer...evidence strongly

${ }^{23}$ John Richard Alden, General Gage in American, 102.

${ }^{24}$ Ibid., 103.

${ }^{25}$ Kenneth C. Davis, America's Hidden History: Untold Tales of the First Pilgrims, Fighting Women, and Forgotten Founders Who Shaped a Nation (New York: Harper Collins Books, 2008), 142.

${ }^{26}$ David Hackett Fischer, Paul Revere's Ride (New York: Oxford University Press, 1994), 96. 
suggests that it was none other than Margaret Kemble Gage, the American wife of General Gage.

This lady had long felt cruelly divided by the growing rift between Britain and America. ${ }^{27}$

Even her husband formed an opinion of his wife's allegiance. So strong were his convictions that he ordered his wife to England. She was packed aboard a ship called the Charming Nancy and sent to Britain. ${ }^{28}$ The Gages became estranged and their marriage was never repaired. ${ }^{29}$

Copley was from a markedly different background than his subject. He was the son of Irish immigrants. The Copley family was near the bottom of the socio-economic spectrum of Boston society. They lived in a small house in Long Warf, from which they sold tobacco. In the mid-1740's Copley's father Richard died of unknown causes. ${ }^{30}$ On May 22, 1748, at Trinity Church, the widow Copley married the Englishman, Peter Pelham, an engraver, portraitist, and tutor. $^{31}$ The Boston News-Letter carried the following advertisement on July 11, 748:

Mrs. Mary Pelham (formerly the widow Copley, on the Long Warf, Tobacconist) is removed [to] Lindel's Row ... where she continues to sell the best Virginia Tobacco, Cut, Pigtail and spun, of all Sorts, by Wholesale, or Retail, at the cheapest Rates. ${ }^{32}$

Judging by her advertisement, Mary Copley Pelham was not only a conscientious and productive shopkeeper, but a zealous competitor, enticing customers with a variety of goods as well as individualized services. Her new husband, Peter Pelham, was an engraver of mezzotints who found it necessary to supplement his income by "teaching young gentlemen and ladies Dancing,

${ }^{27}$ Ibid, 106.

${ }^{28}$ Ibid., 290. The Charming Nancy was a hospital ship for the British Army. When Margaret Gage was onboard it was carrying one hundred and seventy wounded soldiers to the Royal Hospital in Chelsea. A British correspondent reported that while the vessel was in port at Plymouth for a new mainmast some of the ship's passengers went ashore. He reported, "...So much were they [the soldiers] fallen away by sickness and want of proper nourishment...the vessel itself, though very large, was almost intolerable, from the stench arising from the sick and wounded."

${ }^{29}$ Isabel Breskin, "On the Periphery of a Greater World," Winterthur Portfolio 36 (Summer-Autumn, 2001): 120 .

${ }^{30}$ Carrie Rebora et al., John Singleton Copley in America (New York: Metropolitan Museum of Art, 1995), 25-28.

\footnotetext{
${ }^{31}$ Jules David Prown, John Singleton Copley in America, 1738-1774 (Washington: National Gallery of Art, 1966), 8

${ }^{32}$ Ibid., 9.
} 
Writing, Reading, Painting on Glass, and all sorts of Needle Work." 33 Thus the marriage of the widow Copley and Peter Pelham brought together two diverse businesses that, for a while, flourished jointly. It also took a young John Copley, aged ten, from a tobacco shop on Long Warf, to the home and studio of a creative and experienced artist.

Pelham had begun his artistic career in 1713 in London as an apprentice to John Simon, a mezzotint engraver. ${ }^{34}$ After completing a successful apprenticeship in London, in 1727, he immigrated to Boston. ${ }^{35}$ There was little opportunity for Pelham to produce mezzotints in Boston. In order for him to secure a portrait as a basis for a mezzotint it was necessary for him to paint it himself. This is what he did in the case of his 1727 likeness of Cotton Mather (fig. 5). ${ }^{36}$ The arrival of a superior artist, John Smibert (1688-1751), in 1729 was more of a blessing than a setback to Pelham's business. ${ }^{37}$ At least, in theory, Pelham could now concentrate on his own craft of engraving while Smibert produced portraits from which he could make his engravings. However, the market for mezzotints in Boston was slim. It was not until 1750 when Pelham's studio experienced an increase in business, producing seven prints. ${ }^{38}$ It is interesting to note that Pelham was particularly active as an artist during the short time Copley was in his house.

${ }^{33}$ Taken from an advertisement in the Boston Gazette, Jan. 16, 1738, printed in William Henry Whitmore, Notes concerning Peter Pelham: the earliest artist resident in New England (Cambridge: The Press of John Wilson and Son, 1867), 8.

${ }^{34}$ Prown, Copley in America, 7.

${ }^{35}$ According to Prown in John Singleton Copley in America, between 1720 and 1726, Pelham had a successful career in London, publishing twenty-five engravings. The reason for his move to Boston is unknown.

${ }^{36}$ William Henry Whitmore, Notes concerning Peter Pelham, 9.

${ }^{37}$ Richard H. Saunders, John Smibert: Colonial America's First Portrait Painter (London: Yale University Press, 1995), 61.

${ }^{38}$ Prown, Copley in America, 15. 


\section{CHAPTER 2 \\ A Young Artist with Limited Reputation}

Before his sudden death in 1751, Pelham had familiarized Copley with the ways a gentleman should organize his business and cultivate a clientele. ${ }^{39}$ In those three years, he had also introduced his stepson to the mezzotint. After his stepfather's death, Copley, now thirteen years old, turned to the tools readily at hand to help his older stepbrothers support his again widowed mother and his infant half-brother: Pelham's studio with its equipment for making mezzotints. ${ }^{40}$ In 1753, Copley neatly stepped into his stepfather's shoes by producing his first print, a portrait of Rev. William Welsteed (fig. 7), the recently deceased minister of New Brick Church. ${ }^{41}$ As is to be expected, Copley's mezzotint is stylistically similar to work by Pelham. In fact, according to art historian J.D. Prown, it is identical in some parts with Pelham's 1743 mezzotint of Rev. William Cooper (fig. 8). Prown observed that for his portrait of Welsteed Copley had

selected an appropriate Pelham plate...planished out the head, the collar area, and a few selected parts of the inscription below...substituted Welsteed's head and collar, last name, age, and date, as well as his own name as...engraver in the lower left-hand corner. ${ }^{42}$

As was common practice among artists in colonial America, Copley was honing his artistic skills by copying the reproductions and prints that were most easily available to him. By the age of fifteen, Copley had completed his first works, including a handful of portraits and mythological scenes. $^{43}$

${ }^{39}$ Rebora., John Singleton Copley, 29.

${ }^{40}$ The Copley-Pelham marriage was the second marriage for the widow Copley and the third for Peter Pelham, who already had four sons and one daughter. See William H. Whitmore,"The Copleys and Pelhams of New England," Heraldic Journal, IV (Boston, 1868), 175.

${ }^{41}$ Prown, John Singleton Copley in America, 15.

${ }^{42}$ Ibid., 16.

${ }^{43}$ Ibid., 10. 
The most profound influence of Pelham and the operations of his studio upon Copley, more lasting and significant than example or technical instruction or materials on hand, is the most difficult to document. This is the impact of Pelham's beliefs about art and the ideas available to Copley in whatever books his stepfather owned or to which he introduced to his stepson. From the very beginning of his career, Copley seems to have been fascinated by the great unseen world of Western art that lay on the other side of the ocean. From his readings, and perhaps from Pelham as well, Copley developed an exaggerated idea of the sublimity of the works of the great masters, and the importance of the works themselves. ${ }^{44}$ Never having seen any original masterworks, and with no actual experience of the role of the European artist in society, it would seem that Copley's beliefs could have only been developed by what he had read or by what his stepfather had taught him. An example of the extent to which he was influenced by this philosophy can be found in a 1767 letter he wrote to a friend in England of his career in Boston:

Was it not for the preserving the resemble[n]ce of perticular [sic] persons, painting would not be known in the plac[e]. The people generally regard it not more than any other usefull [sic] trade...like that of a Carpenter[,] tailor or shew [sic] maker, not as one of the most noble Arts in the World. Which is not a little Mortifiing to me. ${ }^{45}$

Copley's opinion of artists and their art also manifested itself in the kind of work he did. Copley learned that all types of painting were not equal, that there was a hierarchy to the branches of painting, and that portraiture, the kind of usefully social art for which there was a demand in the American colonies, was of only middling importance. ${ }^{46}$ It ranked far below the highest branch of the profession, history painting. In the best academic tradition, Copley began to explore the

\footnotetext{
${ }^{44}$ John Singleton Copley and Henry Pelham, Letters and Papers of John Singleton Copley and Henry Pelham (Boston: The Massachusetts Historical Society, 1914), 65. See also Prown, 10-15 for Pelham's influence on Copley's artistic philosophy.

${ }^{45}$ Copley-Pelham Letters, 65-66, Copley to Benjamin West or Captain R.G. Bruce, 1767.

${ }^{46}$ Roger de Piles, "The Principles of Painting," in Art in Theory, 1648-1815: An Anthology of Changing Ideas, ed. Charles Harrison, Jason Gaiger, and Paul Wood (Oxford: Blackwell Publishers, 2000), 308-313.
} 
problems of creating complex history paintings by copying the Old Masters. These would not have been idealized attempts to outdo the masters, but straightforward attempts at self-education. However since Boston had little in the way of such paintings, Copley turned to prints.

Not simply content to copy the sources, where Copley felt he could improve on the original composition, he did so. For example, in his Return of Neptune (fig. 9), which is based on an engraving of the subject by Ravenet after Casali (fig. 10), Copley eliminated the cast shadows immediately behind the figures and introduced a real sea and skyscape. ${ }^{47}$ Although the print sources provided composition and a guide to the value range of lighting, they of course had no color. This gave Copley an opportunity to experiment and try his skills as a colorist. In later years, these skills would be what set his work apart from other painters of his generation. Young Copley's attempts in history and mythology painting at the very beginning of his career, when he was only fifteen or sixteen years old, reflect the intensity of his early artistic ambitions. The playful figures cavorting in The Return of Neptune may have served as inspiration for the tortured victims in Watson and the Shark (1778, fig. 11) and The Siege of Gibraltar (1782, fig. $12)^{48}$

Amid Copley's surviving print-derived pictures is a particular image titled Mars, Venus, and Vulcan (1754, fig. 13). Although the source for this painting is not known, it was more than likely based on an eighteenth-century print. In this composition, a youthful and handsome Mars is being disarmed by Venus and three playful cherubs. In the background, Vulcan, Venus's older

\footnotetext{
${ }^{47}$ Albert Eyck Gardner, “A Copley Primitive,” Metropolitan Museum of Art Bulletin, XX (April 1962): $257-63$.

${ }^{48}$ In The Return of Neptune, Copley's treatment of bodies in water is rather distinct. The flesh and skeletal frame of the figures morph as they are submersed to become one with the water. The flesh takes on the color of the water and the frame takes on the shape of the waves. This is particularly evident in the legs of the horses pulling Neptune's chariot and in the legs of the centaur who is blowing a conch-like horn. In Watson and the Shark, the body of Watson dissolves into the water, his hair becoming part of the waves, and his right leg disappearing into the depths, perhaps a symbol of the amputation he suffered as a result of the shark attack. The burning masses of debris and drowning bodies in Defeat of the Floating Batteries at Gibraltar also take on this quality as the remains of the fleets, so solid across the water, assume the characteristics of rolling waves on a tumultuous sea.
} 
and less attractive consort, watches from the shadows waiting to confront the young couple. In the center of the scene, Venus leans on a fabric draped chair. Strands of pearls adorn her loose hair that flows down her shoulder. Illustrating the early development of Copley's mastery of rendering textiles, folds of rich cloth cover her lap. The pose of the voluptuous figure of Venus would be mirrored years later in Copley's portrait of Margaret Kemble Gage (fig. 4).

The most painstaking of Copley's self-educative efforts was his careful preparation in 1756 of a book of anatomical drawings and texts. It digests and compresses material from two European anatomy books, Anatomy Improv'd and Illustrated (1723) and Anatomie der wtterlicke deelen van het Menschelick Lichaem (1634). ${ }^{49}$ The alterations he made to the texts, as well as the ways in which he combined and presented his material, indicate that he was doing much more than transcribing information from published sources (figs. 14-15). He analyzed a substantial amount of information about of human anatomy and put the material in a compact form that would subsequently serve him as a reference work. He kept the book with him throughout his life. After arriving in New York in 1771, Copley soon realized he had left his sketchbook in Boston. He sent for it immediately: "I shall not be able to do long without [it]," he wrote. ${ }^{50}$ The final sheet in Copley's anatomy book is a measured line drawing of the Medici Venus (fig. 16). ${ }^{51}$ The source is probably a book he later mentioned in a letter to his stepbrother Henry Pelham as "the Book of Antique Statues publish'd with their measures." 52

One of Copley's earliest artistic developments occurred in the multi-figural portrait of the Gore children of Boston (fig. 17), done around 1755. The painting is a veritable catalogue of American colonial paintings and serves as strong evidence of the influences that surrounded the

\footnotetext{
${ }^{49}$ Prown, “Anatomy Book by John Singleton Copley,” The Art Quarterly 24 (Spring 1963): 20.

${ }^{50}$ Copley-Pelham Letters, 117.

51 Prown, "Anatomy Book," 20.

${ }^{52}$ Copley-Pelham Letters, 338.
} 
new artist in Boston during the early days of his career. First, the little girl on the left is reminiscent of Smibert's later portraits, such as his 1739 portrait of Jane Clark (fig. 18). The central standing figure, perhaps John Gore, derives from the work of Robert Feke (1705/10-after 1750) in pose and treatment, the pose being the reverse of Feke's James Bowdoin II (1748, fig. 19). The varied positioning of the heads is evocative of John Greenwood's (1727-1792) earlier Greenwood-Lee Family (1747, fig. 20) and Feke's Isaac Royall and Family (1741, fig. 21). The movement is much more restrained in Copley's group, but as in the Greenwood, the gaze of each sitter is locked upon the viewer. ${ }^{53}$

In 1755 a marked change occurred in Copley's work when a competitor, working in the latest artistic fashion arrived in Boston. ${ }^{54}$ Joseph Blackburn (1701-1787) picked up where Smibert, who had died in 1751, left off, taking commissions from some of the same families. ${ }^{55}$ Blackburn convinced his clients that the Baroque compositions favored by Smibert were out of style. ${ }^{56}$ Blackburn was essentially a rococo artist. ${ }^{57}$ The rococo influence on colonial artists had largely been print-borne, but now, Blackburn introduced the style firsthand with his light palette, dexterous touch, and attention to decorative details. With virtually no competition in Boston other than that provided by a local teenaged painter named Copley; Blackburn enjoyed vigorous patronage during the next several years. ${ }^{58}$ Until the late 1760 s, he was the painter who could transform a Boston maiden into a goddess or a Newport girl, like Mary Sylvester, into a comely shepherdess (fig. 22). Such a richness of imagery, along with a precise rendering of the face,

\footnotetext{
53 Edgar P. Richardson, American Paintings and Related Pictures in the Henry Francis du Pont Winterthur Museum (Charlottesville: University Press of Virginia, 1986), 32.

${ }^{54}$ Lisa B. Reitzes, "Faces of a New Nation," in A National Image: the American Paintings and Sculpture Collection in the San Antonio Museum of Art, ed. Lisa B. Reitzes, Stephanie Street, Gerry D. Scott, Shelby Wells (Austin: University of Texas Press, 2003), 20.

${ }^{55}$ Carrie Rebora-Barratt, Carrie Rebora-Barratt, "Faces of a New Nation," The Metropolitan Museum of Art Bulletin, 61 (Summer, 2003): 15.

${ }^{56}$ Ibid., 15.

${ }^{57}$ Elizabeth Louise Roark, Artists of Colonial America (Santa Barbara, California: Greenwood, 2003$), 151$.

${ }^{58}$ Ibid, 152.
} 
brought a new aspect of representation to American portraiture. The construction Blackburn employed for Miss Sylvester was common abroad but novel in the colonies. The gentle shepherdess tends a lamb, which signifies innocence, while the rest of the flock gazes off into the distance, a passage that suggests the young woman's discipline and virtue.$^{59}$ Copley may have been unhappy having to face this keen competition, but his paintings from this time indicate that his reaction was to absorb quickly everything from Blackburn's style that was compatible with his own.

The first glimmer of this development is in the portrait of Ann Tyng (fig. 23). ${ }^{60}$ Ann Tyng was married to Thomas Smelt, a British army officer, in October 1756, and this portrait was probably painted before the wedding so that her family could have a keepsake. ${ }^{61}$ Unfortunately the portrait served as a grimmer memorial, since Ann Tyng died a month after her wedding. ${ }^{62}$ The portrait shows the general characteristics of Copley's first works: a smoky background, streakiness in the fabric highlights, and a tubular quality of the arms and fingers. Ann Tyng does however introduce a new note of elegance that signals the influence of Blackburn's style, particularly in the modeling of her face, as well as the more accurate rendering of the details of her hair and the lace of her dress. Moreover, the rococo emphasis on color seems to have catalyzed Copley's remarkable capabilities as a colorist.

Copley had already been a professional artist for five years by the time he was twenty years old. ${ }^{63}$ During those years he experimented with various modes of artistic expression, but eventually settled down to concentrate on the kind of painting for which there was a consistent

\footnotetext{
${ }^{59}$ Carrie Rebora-Barratt, "Faces of a New Nation," 15.

${ }^{60}$ Prown, John Singleton Copley, 125.

${ }^{61}$ Carrie Rebora-Barratt and Paul Staiti, John Singleton Copley in America (New York: Metropolitan

${ }^{62}$ Ibid.

${ }^{63}$ Ibid, 135.
} Museum of Art, 1995), 134. 
demand, portraiture. Although the arrival of Blackburn may have humbled the young artist, the effect on his art was certainly beneficial. Copley polished his style so that he could compete effectively with the new rival. Blackburn's presence in Boston also seems to have had a healthy effect on the market for art, and far from suffering economically from the competition, Copley enjoyed a growing business. ${ }^{64}$

Blackburn was proving that it was possible for an artist to support himself through painting alone. All of the Boston portraitists from the previous generation had alternative occupations to supplement their incomes. ${ }^{65}$ In supporting himself as a painter, Blackburn obviously had more business than earlier artists. During his years in America, Blackburn averaged twice as many paintings per year as his predecessors, which clearly suggests that the number of portraits produced in Boston between the arrival of Smibert and the arrival of Blackburn was not limited by the availability of artistic talent, but by the restricted demand for portraits. ${ }^{66}$ A growing demand for art in Boston during these years indicates that the economy was strong in this shipping community. Approximately sixty percent of Blackburn's patrons were merchant families. ${ }^{67}$ Merchants and their wives tended to order larger portraits and more often their portraits were painted in pairs. ${ }^{68}$ Reflecting the taste of the merchant families for large canvases, approximately three-fourths of Blackburn's paintings were three-quarter-length portraits. $^{69}$ This designates that not only was he painting more pictures than his predecessors in the colonies, but he was painting larger pictures as well.

\footnotetext{
${ }^{64}$ Prown, Copley in America, 128.

65 Prown, Copley in America, 26.

${ }^{66}$ Lawerence Park, Joseph Blackburn: a Colonial Portrait Painter (Worcester, Massachusetts: American Antiquarian Society, 1923, 23.

67 Ibid, 34. 56.

${ }^{68}$ Lee Kogan and Gerard C. Wertkin, Encyclopedia of American Folk Art (New York: Routledge, 2003), ${ }^{69}$ Ibid., 55.
} 
Blackburn enjoyed a very high level of patronage in America, including numerous wealthy merchants and high-placed officials. ${ }^{70}$ His patrons were largely Anglicans and of what would soon be classified as a loyalist political persuasion. Copley's clients during his early years, though only occasionally equaling Blackburn's in position or wealth, were nonetheless fairly influential people. ${ }^{71}$ It would be expected that a tobacconist's son from Long Warf and Lindel's Row, a young artist with limited reputation, would have begun by painting local craftsmen and small shop owners, a predominately lower-middle-class. Indeed this is generally the case. But from 1755 onward, though his sitters were not primarily the powerful officials and landowners he later painted, Copley did have some notable patrons. Lieutenant-Governor Theodore Atkinson of New Hampshire, Judge Jonathan Belcher, and General William Brattle were some particularly prestigious individuals. ${ }^{72}$ His reputation was expanding beyond the middle-class society of Boston although, at this point, Copley himself had not yet traveled outside Boston for any commission. Copley's new stylistic elegance was coupled with an increase in his business. ${ }^{73}$ The beginning of this flourishing coincided with Blackburn's departure from the colonies in 1762 which left Copley the leading painter in the American colonies, and his commissions multiplied. ${ }^{74}$

\footnotetext{
${ }^{70}$ Ibid., 56.

${ }^{71}$ Prown, Copley in America, 127.

${ }^{72}$ Ibid., 217.

${ }^{73}$ Ibid., 128-129.

${ }^{74}$ Kogan and Wertkin, Encyclopedia of American Folk Art, 56.
} 


\section{CHAPTER 3 \\ In Mr. Copley's Studio}

A great deal can be learned about an artist's process by looking at his studio. While very little is known about Copley's studios, both in Boston and New York, it seems likely that he would have modeled them after the painting room of John Smibert. Smibert's studio was just steps away from Copley's home on Lindel's Row and his own early studios. ${ }^{75}$ A second-story chamber with green walls and an array of artist's materials, Smibert's painting room was the first of its kind in Boston. ${ }^{76}$ Smibert had laid out around his room many of the copies, casts, drawings, prints, and books he had assembled over his time in Europe. ${ }^{77}$ Such a visual feast was simply not available anywhere else in the colonies. There for visitors to see were his copies after Van Dyck's Cardinal Bentivoglio, Raphael's Madonna della Sedia, and at least one painting by Rubens. ${ }^{78}$ In addition, Smibert had brought with him, or had sent later, plaster casts of a bust of Allan Ramsay, a head of Homer, and the Venus de Medici. ${ }^{79}$ These he probably purchased from one of the London statuaries who supplied casts for library decorations in some of the more luxurious English houses. ${ }^{80}$ These classical casts were valued because they transmitted threedimensional images of greatly admired works of art, and they were very likely the first of their kind ever seen in America. Smibert's studio is known to have stunned and fascinated visitors. ${ }^{81}$

${ }^{75}$ Both Prown and Rebora-Barratt remark in their biographies of Copley that Smibert's studio was in the same neighborhood as Copley's boyhood home and his early studios and might have served as a model for Copley's studio.

${ }^{76}$ Saunders, John Smibert, 70.

${ }^{77}$ Ibid., 67.

${ }^{78}$ Ibid.

${ }^{79} \mathrm{Ibid}$.

${ }^{80}$ Ibid., 68.

${ }^{81}$ Ibid. 
It remained intact for about fifty years after the artist's death and most certainly would have served as an inspiration to Copley when he was devising his own working spaces. ${ }^{82}$

The studio Copley designed with the help of his stepbrother, Henry Pelham (1749-1806), as part of Copley's Beacon Hill home was quite large. Built while Copley was working in New York from June to December of 1771, the room had two windows on one wall, and a "Great Window" on the end wall and was twenty-four feet long and seventeen and one-half feet wide, with a ceiling measuring eight and one-half feet, except by the great window, where it was a foot higher. ${ }^{83}$ Pelham raised the ceiling in that area to make it "very commodious for painting a whole length portrait." ${ }^{84}$ Copley painted for the better part of the day. He and his wife kept to a schedule, "We commonly rise by six o'clock in the morning, breakfast at 8 , go about our respective Labours till 3, when we dine." 85

With few exceptions, Copley's sitters came to him. ${ }^{86}$ Therefore, he surely had to have some furniture in his studio. An upholstered armchair with scrolled arms appears in several paintings done in Boston, for example Sarah Boylston (fig. 24) and Elizabeth Smith (fig. 25), suggesting that it may have been his studio chair, at least for a time in the late 1760s. In New York, his studio seems to have been furnished with a camelback sofa, given its appearance, although with different colored upholstery, in his portraits of an unidentified woman (fig. 24) and Margaret Kemble Gage (fig. 4). In his studios, Copley had everything he needed to conduct business as a professional portraitist. ${ }^{87}$ He had a wide variety of supplies, including paints, many brushes, pastel crayons, white, black and red Italian chalk, watercolors, varnish, pencils, ivories,

\footnotetext{
${ }^{82}$ Rebora-Barratt, John Singleton Copley in America, 11 and Prown, John Singleton Copley in America, 36.

${ }^{83}$ Copley-Pelham Letters, 157.

${ }^{84}$ Ibid.

${ }^{85}$ Ibid., 127.

${ }^{86}$ Rebora-Barratt, Transforming Colonists, 10.

${ }^{87}$ Ibid, 9.
} 
paper, and a variety of cloth in different lengths. ${ }^{88}$ In Boston, he purchased what he could from local merchants. ${ }^{89}$ He also enhanced and refined his stock by placing orders with artists and dealers abroad.

A discriminating and demanding consumer, Copley received attentive service from $\mathrm{J}$. Powell in London, who did not merely ship stock supplies to the artists but also "Took The pains To Go To The maker" in hopes that they would meet Copley’s approval. ${ }^{90}$ From Henry and Thomas Bromfield, also in London, Copley ordered colors that were unavailable or hard to get in America, such as the "finest Vermillion," along with brushes, chalk, "fine tools," and "Cloths of the very best kind," remarking that "the last you sent not being equal in goodness to the price.",91 In 1762 he wrote to the Swiss painter and draftsman Jean-Étienne Liotard (1702-1789) for a set of pastels, emphasizing that he wanted only the highest quality crayons: "In a word," he wrote, "let em be a sett of the very best that can be got."92

Copley's studio was the dressing room where he dressed his patrons for their roles in the drama of colonial America. These sorts of metamorphoses could only occur in a studio outfitted in the proper manner by a painter who had not only artistic talent but also a flair for engaging an elite clientele. And yet, very little is known about Copley's working conditions in America. For an artist who worked virtually without competition in America for nearly fifteen years, producing hundreds of portraits for well-known clients, it is astounding that more is not known about how he managed his business. However, while a precise picture of Copley's studios may never be fully known, it is possible to map out an approximate representation of the sizes and conditions of his work spaces, to reconstruct a partial inventory of supplies and props, and to

\footnotetext{
${ }^{88}$ Ibid.

${ }^{89}$ Ibid, 12.

${ }^{90}$ Copley-Pelham Letters, 37.

${ }^{91}$ Ibid., 115.

${ }^{92}$ Ibid., 26.
} 
envision what it must have been like to be Margaret Gage walking into Copley's studios to be immortalized by a master. ${ }^{93}$

${ }^{93}$ Mrs. Gage's first meeting with Copley was on Monday, June 17, 1771. Carrie Rebora-Barratt, Turkish Fashion in $18^{\text {th }}$-Century America (San Diego: The Timkin Museum of Art, 2007), 7. 


\section{CHAPTER 4 \\ The First American Realist}

When Copley travelled to New York in 1771, he was at the pinnacle of his career and had no equal in the colonies. The phenomenal talent of the Bostonian artist was well known and admired by many in the Hudson area. If New Yorkers wished to see examples of Copley's work, in the city there were two portraits of men who had visited Copley in Boston: General Thomas Gage (fig. 27) ${ }^{94}$ and the Reverend Myles Cooper, second president of Columbia College (fig. 28). Early in 1771, Captain Stephen Kemble, brother of Margaret Gage, entered into correspondence with Copley urging him to visit the city. Captain Kemble wrote to "Mr. Copley":

If he inclines to come to New York in the Spring, or Summer. If he does, he will specify the time he proposes to stay, and the number of Picktures [sic] he would undertake to draw. . .Capt.

Kemble will then send Mr. Copley the Names of those, who will employ him, that Mr. Copley may be at a Certainty. ${ }^{95}$

Copley replies, offering to stay in New York long enough to complete twelve or fifteen half lengths and naming his price: "Whole Lengths 40 Guineas, half Length 20, 1/4 pieces or Busts 10. .."96 These New York prices are markedly higher then what Copley was charging in Boston for what Copley called "obvious reasons." ${ }^{97}$ By April seventeenth, Captain Kemble was able to send Copley a list of subscribers. That list has been preserved only partially, unfortunately, but

${ }^{94}$ It would not be for another three years until Copley would begin to work on the portrait of Mrs. Gage. While Isabel Breskin in "On the Periphery of a Greater World: John Singleton Copley's Turquerie Portraits," lists the Gages' portraits among those painted by Copley as pendants (see page 112), there is no evidence that these paintings were commissioned as such or were even ever hung together. Rebora-Barrat states in Turkish Fashion in $18^{\text {th }}$-Century America, "Mrs. Gage's portrait evinces a complete disregard for the notion that the two pictures would ever hang as pendants" (see page 38). Therefore, for this research, Mrs. Gage's portrait will be considered as an independent painting.

95 John Singleton Copley and Henry Pelham, Letters and Papers of John Singleton Copley and Henry Pelham, 1739-1776 (Boston, MA: Massachusetts Historical Society, 1914), 112.

${ }^{96}$ Ibid., 113.

${ }^{97}$ Jules David Prown, Art as Evidence: Writings on Art and Material Culture (New Haven: Yale University Press, 2001), 31. 
the name at the top of the list is significant, "Mrs. Gage."98 Copley traveled to New York in June of 1771 with his wife Susannah. They remained in New York until Christmas Day of that year. ${ }^{99}$ This is the first time Copley would travel outside of Boston for work. Several reasons may have led to his decision to answer New York's invitation. One factor may have been that with the deteriorating political condition in Boston, Copley's commissions were beginning to slacken. ${ }^{100}$ However, personal considerations were likely more important. With Copley's recent marriage he had purchased twenty acres of land with three houses on it in Beacon Hill. ${ }^{101}$ His expenses were rising rapidly. He had a growing family to provide for, and property to enlarge and remodel to make into an artist's studio. The artist had to find greater opportunity and the New York request had come at just the right time.

More is known today about Copley's time in New York than of his life in Boston because of the correspondence between him and his stepbrother Henry Pelham. These letters have been preserved, documented, and published by the Massachusetts Historical Society. On June sixteenth, Copley wrote to Pelham that they had had a good trip from Boston to New York, they were settled in a spacious house, and he was "ready to begin Mrs. Gage's portrait tomorrow." 102 Copley's New York studio was on lower Broadway and seemed to have pleased him very much: "My large Chamber is about 9 feet high and 20 feet long and as near as broad, with a good room adjoining it, the ligh[t] near north." 103

The room adjoining Copley's studio would have most likely been used as a consultation room or a waiting room. It was an area for conversation with his clients. This would have been

\footnotetext{
${ }^{98}$ E.P. Richardson, “Copley’s New York Portraits," Winterthur Portfolio (1965): 6.

${ }^{99}$ Louise Burroughs, "John Singleton Copley," The Metropolitan Museum of Art Bulletin, no. 12 (December 1936): 256 .

${ }^{100}$ Prown, Art as Evidence, 28.

101 Ibid., 30.

102 John Singleton Copley and Henry Pelham, Letters and Papers of John Singleton Copley and Henry Pelham, 1739-1776, 33.

103 Ibid., 77.
} 
a social as well as a business interaction. It would allow the patron to learn more about the artist and his work, and at the same time, the artist would gain insight into the personality of the patron. Copley's occupation required talent, of course, but equally as important, it required respect and patience for the refined manners and social decorum of his upper class patrons. In his reception room, Copley would not only display examples of his own work, he would also have portfolios of prints, from which his clients, including Mrs. Gage, could choose different poses and costumes. ${ }^{104}$

Copley's methods for working allowed him the opportunity to capture unprecedented detail in his portraits. Copley had a reputation for asking his patrons to pose for him more frequently and for longer periods of time than any of the other artists at the time required of their subjects. ${ }^{105}$ Several of Copley’s sitters would later remark on the considerable amount of time they had to sit for the artist. Mrs. Sargent reportedly sat for Copley fifteen or sixteen times, six hours at a time. ${ }^{106}$ His contemporary, Sir Joshua Reynolds, working in London, told an inquiring potential patron, "It requires in general three sittings about an hour and a half each time but if the sitter chooses it the face could be begun and finished in one day... when the face is finished the rest is done without troubling the sitter.",107

In corroboration of Reynolds's five-hour estimate, one of his patrons told the artist's biographer, "I sat for him [Reynolds] five hours, in which time he finished my head, and sketched out the rest of my figure." ${ }^{108}$ Similarly, the author of a popular midcentury text on painting, in the widely circulated Universal Magazine outlined the process by which a portrait

\footnotetext{
${ }^{104}$ Carrie Rebora, "Transforming Colonists into Goddesses and Sultans: John Singleton Copley, His Clients, and Their Studio Collaboration," American Art Journal, no. 1-2 (1995-1996), 17.

105 Ibid., 20.

${ }^{106}$ Rebora-Barratt, John Singleton Copley in America, 45.

${ }^{107}$ Joshua Reynolds, Frederick Whiley Hilles, ed. Letters of Sir Joshua Reynolds, (Cambridge: The University Press, 1929), 56

${ }^{108}$ John Sime, Sir Joshua Reynolds (London: Methuen and Company, 1903), 62.
} 
was to be executed in three sittings totaling about ten hours, almost the entirety of which was devoted to the process of painting the face. ${ }^{109}$ Assisting the painter in the prompt execution of commissions was the standardization of formats, including whole-length (94 by 58 inches), halflength (47 by 29 inches) which was the size most popular with Copley's patrons, and bust (30 by 25 inches, including one or both hands). ${ }^{110}$ Suppliers on both sides of the Atlantic provided stretched, primed canvases in these sizes, and artists charged their customers accordingly. ${ }^{111}$ Each format incorporated set expectations and conventions concerning portions of the body to be included and the position of the head on the canvas. ${ }^{112}$

So, accounting for Reynolds's urbanity and confidence in his efforts to secure a client and Copley's self-taught, provincial status, the disparity is enormous: ninety hours with the sitter as opposed to Reynolds's five to eight. It suggests that Copley needed the sitter present to evaluate and capture every nuance of color, tone, and form. It also suggests that Copley was a ruthless empiricist, erasing from his mind all thoughts of convention and memory, concentrating on firmly and rendering purely those forms and colors received by his eye. A second corroborating account of Copley's working methods was recorded by his colleague Benjamin West, who reported that Copley "was the most tedious of all painters. When painting a portrait, he used to match with his palette-knife a tint for every part of the face. . This occupied himself and the sitter a long time before he even touched the canvas." 113

Indeed, Copley has long been heralded as a realist, the first America painter to master the difficult language of Renaissance painting, convincingly rendering matter three-dimensionally

${ }^{109}$ Ellen Gross Miles, The Portrait in Eighteenth Century America (Delaware: The University of Delaware Press, 1993), 81.

${ }^{110}$ Robin Simon, The Portrait in Britain and America (Boston: G.K. Hall, 1987), 111-112; and Prown, John Singleton Copley, 45.

${ }^{111}$ Ibid., $111-112$.

${ }^{112}$ Ibid., 112.

${ }^{113}$ West conversation with C. Robert Leslie, recorded in Dunlap, History, 126. 
with exactitude in simulation of forms and features before his eyes. Some historians of American art have seen in Copley's works the beginning of a defining three-century tradition of realism in American painting. Scholars of this school, such as Barbara Novak and Wayne Craven, emphasize Copley's seemingly self-taught nativist artistic achievement and tend to both celebrate and empathize with the persevering artist and his back-water patrons. For Wayne Craven, for instance, these "two beautifully matched parties - the native-born artist and his provincial mercantile patron" were guided by virtues and values of "industry, frugality, sobriety, and moderation." They "sought a middle course between the lower level of the dull-witted poor and the extravagances and vanities as they existed in the corrupt and immoral segments of European aristocracy," expressing their American "materialism, pragmatism, utilitarianism, and egalitarianism...independence, self-sufficiency, and self-confidence" with pictorial assemblages exhibiting an appropriate cultural Calvinism - "prosperity was a reflection of God's favor."114

An opposing interpretation of Copley's work downplays its realism, its replication of empirical vision, and emphasizes instead the artist's capacity to fictionalize under the guise of verisimilitude, focusing on Copley's embrace of artifice, imitation, and convention. These scholars, notably Timothy Breen and Paul Staiti, contend that he was not, in fact, a realist. They argue that neither the faces nor the material culture with which he equips his sitters in his portraits are records of optical experience, Copley was, they propose, essentially, "choreographing theatrical pantomimes calculated to flatter pretentious nervous provincials." By constructing these exaggerated realities, Copley was complicit with insatiably envious

${ }^{114}$ Barbara Novak, American Painting of the Nineteenth Century: Realism, Idealism, and the American Experience (New York: Harper and Row, 1979), 10, 15-24; and Wayne Craven, Colonial American Portraiture: The Economic, Religious, Social, Cultural, Philosophical, Scientific, and Aesthetic Foundations (Cambridge: Cambridge University Press, 1986), 9, 111, 126, 259, 304, 318-350.

${ }^{115}$ Paul Staiti, "Accounting for Copley," in Carrie Rebora et al., eds., John Singleton Copley in America (New York: Metropolitian Museum of Art, 1996), 25,28,29,32,33,37,40; T.H. Breen, "The Meaning of Likeness': American Portrait Painting in an Eighteenth-Century Consumer Society," Word and Image 6, no. 4 (OctoberDecember 1990): 35-50. 
Bostonians whose inflated sense of self-worth expressed underlying provincial anxiety and dreams of upward mobility.

While the previous scholars frame their discussions in terms of a judgmental tale in which honest Americanisms triumph over corrupt Europeanisms, scholars such as Breen and Staiti raise a moral tale in which individual vices and neuroticisms are ascribed to a whole society. ${ }^{116}$ However, while the grounds of discussion and dispute appear to revolve around the painterly conventions and working habits, in fact, all these art historians are arguing about what could be broadly termed the moral tone of colonial elites and Copley's position as an instrument of their self-imagining.

That Copley's portraits were perceived to incorporate a deceptively magical replication of reality is suggested by a tale recounted by one of Copley's sitters of the patron's fifteenmonth-old child who,

When he eyed your Picture, he sprung to it, roared, and schriched, and attempted gripping the hand, but when he could not catch hold of it, nor gett You to speak to him, he stamp'd and scolded, and when any of us askt him for Papa, he always turned, and pointed to the Picture. What think [you] of this proof of the Painters Skill in taking Your likeness? ${ }^{117}$

That adults also took Copley's portraits seriously as substitutes for the individuals depicted is indicated by the fact that, in the heated riots that preceded the Revolution, a mob entered Harvard Hall and cut the "heart" from the portrait of Governor Francis Bernard hanging there. ${ }^{118}$ However, despite their foundation in the exact replication of certain aspects of the threedimensional world before the painter, all portraits are, to some extent, based on convention, artifice, and fiction, and all respond to the strictures of their culture in terms of dress, body type,

\footnotetext{
116 Ibid.

${ }^{117}$ Prown, John Singleton Copley, 167.

${ }^{118}$ Copley-Pelham Letters, 67-70; Prown, 43. The location of the Bernard portrait is now unknown.
} 
deportment, accoutrements, and even facial expression. In this regard, Margaret Gage's portrait is certainly no exception.

Light, entering from the left, illuminates Mrs. Gage's oval face. She is striking by almost any standard of beauty, with deep-set brown eyes, heavy eyebrows, long nose, and small mouth. Two small brown marks, one on either side of her mouth, suggest that Copley made some attempt to turn the corners of her mouth into a smile, but she remains enigmatic. ${ }^{119}$ She wears an entirely natural expression, an expression that is also prescribed for a woman dancing. In other words, presenting herself as a work of art, "Let the Eyes appear lively and modest, and the Face express neither Mirth nor Gravity, but the Medium, which will form an admirable Mein and always be agreeable."120 The portrait makes an exemplary aesthetic statement. As a self-taught student of art and aesthetic theory, Copley would have no doubt been familiar with the deportment of natural attitudes as an enhancement to loveliness; as Joseph Addison wrote in 1712, "the Picture of a Face that is beautiful... is still greater, if the Beauty be softened with an Air of Melancholy..." ${ }^{121}$ Melancholy, in eighteenth-century aesthetic parlance, might have connoted a sense of romanticism but more often signified the presence of intellect and a certain sophistication. ${ }^{122}$

Mrs. Gage's throat and décolletage are an expanse of ivory and cream, interrupted by two strands of delicate, miniature pearls and their trailing ribbon clasp framed by the square neckline of her gown. Further highlighting her loveliness, her cheeks, bracketed and heightened by notes

${ }^{119}$ Rebora-Barratt, Turkish Fashion, 15.

${ }^{120}$ F. Nivelson, The Rudiments of Genteel Behavior (London, 1737), "Dancing," n.p.

${ }^{121}$ Joseph Addison, "The Rugged Thorn Shall Bear the Fragrant Rose," The Spectator, Vol. 6 (London, J and R Tonson in the Strand, 1776): 90.

${ }^{122}$ Ibid, 90. See also Christopher John Murray, "Melancholy," Encyclopedia of the Romantic Era: 17601850 (New York: Fitzroy Dearborn, 2004), 722. According to Jennifer Raddon another of melancholy's associations is with the state of idleness, with aristocratic and courtly boredom, and with the division of labor within social groups. Therefore, expressing melancholy in a portrait would have also been a sign of the subject's high social status. Jennifer Raddon, The Nature of Melancholy: From Aristotle to Kristeva (New York, Oxford University Press, 2000), 18. 
of pink, display a blush indexical of feminine virtue. Explicitly connecting the flushed cheek to female chastity, an English fictional protagonist of the period opined, "A delicate virtue is like a delicate chastity that will blush with a reddening which, in scripture, is called the most becoming cloathing [sic] and best ornament of a woman." 123 This involuntary body language, perhaps revelatory of her personal character, also squarely situated Mrs. Gage in an eighteenth-century social convention of gender-specific virtue. Her culture's hostility to counterfeit blush is evident in the text of an unsuccessful Parliamentary bill put forward in 1770 declaring that "women of whatever rank...that shall... seduce and betray into matrimony, any of his Majesty's subjects by the scents, paints, cosmetic washes...shall incur the penalty of the law now in force against witchcraft." 124 In such documents and in the prescriptive literature concerning the presentation of the body, naturalness was a clearly approved value. The color and texture of Mrs. Gage's exposed skin is quite white, perhaps recording her paleness but also acknowledging the social proscription of skin exposed for sustained periods to the sun or, to smallpox, or other alteration. Skin figured as a marker and a metaphor for youth and therefore health. Skin was not sought, even in men, as an index of experience. ${ }^{125}$

Setting off the whiteness of her skin is the lace that echoes it and the dark blue Chippendale-inspired sofa that contrasts it vividly. Blue is a curious color for Copley to have chosen to paint this piece of furniture. ${ }^{126}$ It has aristocratic connotations, of course, "blue blood" or "true blue."127 The Virgin Mary's clothing is traditionally blue, often painted with ultramarine which is crushed lapis lazuli, of a value rivaled only by gold. In heraldry it is called azure,

${ }^{123}$ David Piper, The English Face (London: Thames and Hudson, 1957): 189.

${ }^{124}$ Ibid., 124.

${ }^{125}$ Ibid., 234.

${ }^{126}$ It is not known if the sofa was actually blue. In another portrait done by Copley during his New York visit he paints a woman reclining on sofa similar to the piece Gage poses on in every way, except it is red (fig. 5). Rather than having two different sofas, it is more likely that Copley used the same couch in both portraits and changed its color when he painted it to coordinate with each composition.

${ }^{127}$ Michael Pastoureau, Blue: The History of A Color (London: Princeton University Press, 2001), 63. 
retaining etymologically its association with precious lapis lazuli. In the eighteenth century, blue was associated with true faith, continued affections, and constancy. In art, it is the color of celestial space and also of distance and, from the early eighteenth century, of shadows. ${ }^{128}$

Sofas were a relatively new form of furniture for the time, having evolved from a combination of earlier settees and fully upholstered easy chairs. ${ }^{129}$ Between the mid-seventeenth century and the end of the eighteenth century, European beds and seating changed in ways that mirror a broader trend toward lighter, more informal furnishings. ${ }^{130}$ These furnishings' forms followed the contours of the body, accommodated layers of undergarments and panniers, and promoted conversation. ${ }^{131}$ Comfortable chairs such as canapés, sofas, ottomans, and duchesses, among others began to appear. These new forms, hybrids between the bed and the chair, responded to the new emphasis on comfort and sociability; benches and church pews aside, they were the first seats designed for several occupants. ${ }^{132}$ The oriental, feminine names commonly conferred on them, sofas; ottomans; paphoses; and turquoises, evoked a distant impression of the Turkish divan, the row of cushions arranged against a wall that European travelers encountered in The East. ${ }^{133}$

Since most houses in the colonies during this time period had limited space, and since the amount of fabric required to upholster a sofa was expensive, they were only affordable to the wealthy. However, during the mid- to late-eighteenth century, the prosperity of the colonies had enabled the upper classes to amass considerable wealth. This prosperity fostered a desire in the

\footnotetext{
${ }^{128}$ Ibid., 13, 54, 56. According to The Artist's Repository (London, 1784-86), ultramarine cost from 3 to 10 guineas per ounce during the 1780s (less expensive but less optically desirable blue pigments available in the eighteenth century included smalt, turchino, bice, and verditer).

129 Jeffery P. Greene, American Furniture of the $18^{\text {th }}$-Century (Connecticut: Taunton Press, 2001), 50.

${ }^{130}$ Dena Goodman and Kathryn Norberg, eds., Furnishing the Eighteenth Century: What Furniture Can Tell Us about the European and American Past (New York: Routledge, 2007), 14.

${ }^{131}$ Ibid., 16.

132 Ibid., 15.

133 Ibid., 16.
} 
affluent to fill their homes and surroundings with elegant and beautiful objects. In an effort to infuse a richness into their furnishings, Americans embraced the English styles propagated by Thomas Chippendale in which understatement yielded to bold presence.

Thomas Chippendale (1718-1779) is credited with having combined French style, Rococo ornament, Chinese design, and a passing interest in the Gothic into a furniture design book that captured the imaginations of American designers. ${ }^{134}$ That book was The Gentleman and Cabinet-Maker's Director, published in April 1754. ${ }^{135}$ The Director ushered in a new era in furniture design that forever changed the look of American furniture. The Chippendale style offered the opulence that the upper echelon of the American market wanted. Their homes were becoming increasingly palatial, and they were accustomed to having the most fashionable clothing, rich European and Oriental textiles, delicate Chinese porcelain and sparkling silver and glassware. The majestic appearance of the new furniture, intricately carved in rich mahogany and finished to a glossy luster, fit perfectly into their world. The Chinese aspects of the Chippendale style were of great interest to Americans. ${ }^{136}$ Not only was there an ongoing merchant trade with the Orient, but also the simple geometry of the designs appealed to them. ${ }^{137}$ The designs were pure and elegant in their simplicity and conveyed just enough of an exotic nature to make them interesting, but not foreign.

Upholstered sofas reached a stylistic peak during this period of prosperity in the colonies. Those who could afford them wanted to be sure they would be the focal point of any room, as certainly the sofa Mrs. Gage sits upon would have been. However, what marks this sofa as Chippendale-inspired is what is underneath. Many Chippendale designs feature straight molded

\footnotetext{
${ }^{134}$ Ibid., 61.

135 Ibid.

136 Ibid., 65.

${ }^{137}$ Ibid.
} 
legs with or without square block feet called Marlborough legs. ${ }^{138}$ The few camelback sofa designs that appear before the Chippendale style feature cabriole legs. ${ }^{139}$ The design of the sofa in Mrs. Gage's portrait is the only visual element that locates her with some degree of specificity to a parlor in Britain or its colonies. Rectilinear upholstered sofas made with simple stretchers, show the influence of Chinese structure on Chippendale's designs, and are an important subset of American Chippendale design. ${ }^{140}$ American designers used shallow s-shaped curves in their designs. These curves had been in favor with late Baroque designers as an essential element in all things beautiful. ${ }^{141}$ Serpentine backs and sweeping arm rolls build an elegant form on which to display vast stretches of the finest imported fabrics. The arm of the sofa, whose shape is defined by the volute pattern of gleaming, closely spaced brass upholstery tacks, beautifully echoes Mrs. Gage's pose.

Margaret Gage's dress is apparently made of a salmon-colored satin weave, heavy silk fabric, probably paduasoy. ${ }^{142}$ Silk had been imported into the colonies from the earliest days of settlement and remained throughout the colonial period a fabric associated with the elite among colonists of both genders as well as, perhaps surprising, some Native Americans. ${ }^{143}$ While legislation throughout the colonial period encouraged the development of a North American silk culture, most silk in American came from Asia and continental Europe and therefore was either highly taxed or smuggled into the country and consequently was very expensive. ${ }^{144}$ That some

${ }^{138}$ Ibid., 76.

${ }^{139}$ Ibid.

140 Ibid., 75.

141 Ibid., 34.

${ }^{142}$ Regarding the fabric see Rebora-Barratt, Turkish Fashion, 18. Rebora-Barrat proposes that Margaret Gage may have owned the dress in which she is depicted because of the "palpable" quality of Copley's treatment of the fabric. While Gage's father was born in Smyrna and lived there until he was sixteen, there is no absolute proof that she or her family owned such a dress. See Turkish Fashion, 20-21.

${ }^{143}$ Linda Baumgarten, What Clothes Reveal: The Language of Cloth and Clothing in Colonial and Federal America (Virginia: The Colonial Williamsburg Foundation, 2002), 67 and 71.

144 Ibid., 82. 
silk was produced in America in the eighteenth century is evidenced by travelers' accounts and such paintings as Ralph Earl's Mrs. Charles Jeffrey Smith of 1794 (fig. 29), which includes a small crop of silkworm cocoons as the sitter's principle attribute, but local production was always modest and demand high. ${ }^{145}$ Gage's dress, then, suggests, in the intrinsic value of the visible, imported materials, the unpicturable value of its wearer as a member of the most socially prominent circle in New York society.

${ }^{145}$ The New York Historical Society, "Mrs. Charles Jeffery Smith (Elizabeth Woolsey Smith, 1736-1816)," The Henry Luce III Center for the Study of American Culture, http://emuseum.nyhistory.org/code/emuseum.asp?style=Browse\&currentrecord=1\&page=search \&profile=objects\&s earchdesc=Ralph\%20Earl\&quicksearch=Ralph\%20Earl\&newvalues=1\&newstyle=single\&newcurrentrecord=3 (accessed June 3, 2010). 


\section{CHAPTER 5}

Turkish Inspirations

The style of Mrs. Gage's dress is based on the eighteenth-century British fashion called turquerie. The style originated in England with an interest in all things oriental, which grew with the British empire and the expanding European trade connections in the East. The Ottoman Empire, declining as a military power since the end of the seventeenth century, began to allow access to western European travelers who had long been intrigued by the secret, autocratic, and above all exotic court in Constantinople. ${ }^{146}$ Turkey, since the Renaissance, had exported fine silks and embroideries to the west through Venetian merchants, and such trading links were further strengthened by the establishment of diplomatic facilities granted in particular to France, England, and Holland in the late seventeenth century. ${ }^{147}$ Similarly, Turkish ambassadors appeared in European courts where their presence began inspiring artists, writers, musicians and actors.

During the seventeenth century a number of foreign artists had settled in Constantinople, painting members of the merchant and diplomatic communities and their families. ${ }^{148}$ Works by French artists, such as Jean-Baptiste Vanmour in his Recueil de Cent Estampes representant differentes Nations du Levant (1714), offered Europe a glimpse into the foreign life of the Ottoman court and provided detailed etchings and descriptions of its dress. ${ }^{149}$ An increasing number of young European men extended their Grand Tour to include the newly-fashionable East. ${ }^{150}$ Perhaps most influential in creating the British vogue for turquerie, however, were the

${ }^{146}$ Said, Orientalism, $75-76$.

${ }^{147}$ Vadime Elisseeff, The Silk Roads: Highways of Culture and Commerce (New York: Berghahn Books, 2000), 34.

148 Jennifer M. Scarce, Women's Costume of the Near and Middle East (London: Routledge, 2003), 57-59.

${ }^{149}$ Ibid., 40. 2000), 14

${ }^{150}$ Brian S. Turner, Readings in Orientalism, Orientalism: Early Sources Volume 1 (London: Routledge, 
letters of Lady Mary Wortley Montagu who traveled to Turkey in 1717 when her husband was posted at the English embassy there. ${ }^{151}$ Her collected letters vibrantly describe Turkish culture and costume. In a 1717 letter to her sister Lady Mar in Paris Montagu describes her clothes in great detail:

The first part of my dress is a pair of drawers, very full, that reach to my shoes and conceal the legs more modestly than your petticoats. ... Over this hangs my smock, of a fine white silk gauze. . .. This smock has wide sleeves, hanging half-way down the arm. . . The antery is a waistcoat made close to the shape, of white and gold damask, with very long sleeves falling back and fringed with deep gold fringe, and should have a diamond or pearl buttons. . . .My caftan, of the same stuff as my drawers, is a robe exactly fitted to my shape, and reaching to my feet, with very long straight falling sleeves... . The curdee is a loose robe of rich brocade either lined with ermine or sables.... With this dress noble Turkish ladies wore on their heads either a small velvet cap decorated with pearls or diamonds, an embroidered silk handkerchief or an aigrette of feathers or jeweled flowers. ${ }^{152}$

Lady Montagu's costume, as it was interpreted in England, formed the basis of the turquerie style: a fur-trimmed, often ermine, robe with hanging sleeves, a caftan, baggy trousers, and a turban or asymmetrical headdress of feathers, tassels, or pearls. Widely circulated in manuscript form during her lifetime, the letters were published in London after her death in 1763 . The interest in turquerie in America can be attributed in part to Lady Montagu's far-reaching influence. In 1766 and again in 1768, her collected letters were published in America and became a favorite at many lending libraries. ${ }^{153}$ The book's popularity lasted well into the 1790 s, when selected letters were serialized in the first issues of The Lady's Magazine. ${ }^{154}$ Montagu's

${ }^{151}$ Aileen Ribeiro, The Art of Dress: Fashion in England and France, 1750-1820 (New Haven: Yale University Press, 1995), 134.

${ }^{152}$ Mary Wortley Montagu, James Archibald Stuart-Wortley-Mackenzie-Whamcliff, William Moy Thomas, Louisa Stuart, The Letters and Works of Lady Mary Wortley Montagu, Volume 2 (London: George Bell and Sons, 1898), 243.

${ }_{153}$ Kevin J. Hayes, A Colonial Woman's Bookshelf (Knoxville: University of Tennessee Press, 1996), 120. 2002), 266.

${ }^{154}$ Aileen Ribeiro, Dress in Eighteenth Century Europe, 1775-1789 (New Haven: Yale University Press, 
account of the Turkish dress she habitually wore as well as the turquerie portraits she had commissioned, inspired many English women to copy her dress for masquerade balls. ${ }^{155}$

For both masquerade-goers and artists there were a variety of sources of ideas for costumes; these included engravings, or records of famous masquerades such as Caravanne $d u$ Sultan à la Mecque performed by the students of the French academy in Rome in 1748 and depicted by one of the participants, J.M. Vien. ${ }^{156}$ This source was used in Thomas Jeffrey’s masquerade pattern book of 1757, A Collection of Dress of Different Nations both Ancient and Modern, and more particularly Old English Dresses after the designs of Holbein, Vandyke, Hollas, and others, an important publication for the spread of certain fancy dress costumes. ${ }^{157}$ Society ladies wished to appear in their portraits in Turkish costume; in 1755, Madame de Pompadour commissioned Carle van Loo to paint a series of portraits of her as a sultana for her chateau of Bellevue (fig. 30), and Jean-Etienne Liotard's clients included ladies as different as the beautiful Countess of Coventry (fig. 31) and the daughter of Louis XV, Marie Adélaïde (fig. $32) .{ }^{158}$

Some aspects of Turkish costume were approved of by artists who preferred the flow of drapery to the details of European fashions with all their trimmings and accessories. Angelica Kauffmann, for example, painting fashionable sitters in the 1770 s, found that the modish oriental dishabille of loose-fitting, cross-over muslin gown decorated with braid and fringe worn with a sash, fitted in her ideas about simple classical Greece, such as her depiction of Penelope Weeping Over the Bow of Ulysses (1779, fig. 33). ${ }^{159}$ To her contemporary Sir Joshua Reynolds,

\footnotetext{
155 Ribeiro, The Art of Dress, 136.

${ }^{156}$ Ribeiro, Dress in Eighteenth Century Europe, 268.

${ }^{157}$ Ibid., 268-269

${ }^{158}$ Emilia Dilke, French Painters of the Eighteenth Century (London: George Bell and Sons, 1899), 202, and Ribeiro, Dress in Eighteenth Century Europe, 268.

${ }^{159}$ Ribeiro, The Art of Dress, 158.
} 
however, such "eastern dresses", although rich and dignified, had "a mock dignity in comparison with the simplicity of the antique."160

Turquerie was gradually Westernized and, as the century progressed, altered to reflect the British fashion for classically-inspired, looser-fitting, informal clothing. Costume historian Aileen Ribeiro identifies two simultaneous trends in later versions of turquerie. The first consisted of a loose gown made of light-color silk, embroidered muslin, or printed gauze edged with gold and often fastened with a fringed sash. ${ }^{161}$ From the 1750s on, feathers, scarves, and pearls increasingly took the place of the turban. ${ }^{162}$ Tight sleeves were replaced with wider chemise sleeves. ${ }^{163}$ Even as it was diluted, this informal turquerie was still worn to masquerade balls in Britain and was considered very fashionable. Many women in Copley portraits, including Margaret Gage, wear a version of this informal turquerie, further diluted in its Atlantic crossing. The second trend in turquerie featured a fur-lined overgown worn over a simple, loose, cross-over dress, with a sash tied at the waist. ${ }^{164}$ Copley painted a number of women wearing this second turquerie style. ${ }^{165}$ Martha Lee, for example, cuts an imposing figure as she mounts a flight of stairs; her ermine robe spilling behind her (fig. 34). She calmly, even imperially, meets the viewer's gaze.

${ }^{160}$ Sir Walter Armstrong, Sir Joshua Reynolds: First President of the Royal Academy (New York: Charles Scribner's Sons, 1905), 91.

${ }^{161}$ Ribeiro, Dress in Eighteenth Century Europe, 178.

${ }^{162}$ Ibid.

${ }^{163}$ Ibid., 179.

${ }^{164}$ Ibid.

${ }^{165}$ Elizabeth Ross (Tyng) fig. 42, Martha Lee fig. 34, and Abigail Babcock fig. 46 all appear in this second turquerie style. 


\section{CHAPTER 6}

\section{A Love of All Things British}

Current scholarship argues that the American women who dressed in turquerie for their portraits were being fashionable. Paul Staiti writes, "It is understandable that Mrs. Gage might wish to be portrayed in turquerie, for that was the thing to do in England." 166 Identifying her as an "elite Englishwoman by marriage," Staiti reads her portrait as an attempt to claim membership in a distant social class. Carrie Reboa-Barrat links the costume not to Gage's married identity, as Staiti does, but to her foreign ancestry; her paternal grandmother was Greek, and her father had been born in Smyrna. ${ }^{167}$ Rebora also ascribes Gage's decision to wear turquerie for her portrait to style, remarking that she "would have wanted to follow the English fashion [her Turkish dress] represented." ${ }^{168}$ In some ways Staiti's and Rebora's assessments are perfectly accurate; there are a myriad of examples of Americans copying British fashions and abundant evidence that they did so with avarice.

In 1771, William Eddis, a British official posted in the American colonies remarked, "The quick importation of fashions from the mother country is really astonishing. I am almost inclined to believe that a new fashion is adopted earlier by the polished and affluent American than by many opulent persons in the great metropolis. ${ }^{\not 169}$ Conversely, another writer commented, "What a pity it is that fashions wear out in London before they can arrive at New York or Philadelphia... .If there was a glass in the moon, we might catch the fashions as they

${ }^{166}$ Paul Staiti, "Character and Class," in Rebora, John Singleton Copley, 67.

${ }^{167}$ Carrie Rebora, "Catalogue Entry 66-67," in Rebora John Singleton Copley, 291.

${ }^{168}$ Ibid. 1969), 57.

${ }^{169}$ William Eddis, Letters from America, ed. Aubrey C. Land (Cambridge: Harvard University Press, 
rise." ${ }^{170}$ In a 1774 poem, the patriotic author Mercy Otis Warren (fig. 35) compared Americans' love of all things British to the persecuted Israelites desire for Egyptian goods,

When Pharoah, harden'd as a G__ in crimes,

Plagu'd Israel's race, and tax'd them by law,

Demanding brick when destitute of straw;

Miraculously led from Israel's port,

They lov'd the fashions of the tyrant's court;

Sigh'd for the leeks, and water of the Nile,

As we for geegaws from Britannia's Isle... ${ }^{171}$

Warren's poem, while supporting the notion that Americans chased English styles with abandon, also reveals the inadequacy of fashion as a full explanation for the wearing of turquerie. ${ }^{172}$

Colonial Americans were not simply mirroring the style of the governing metropolis; they coveted items from "the tyrant's court." The very act of purchasing these items, making free choices from among competing possibilities, heightened the Americans' developing sense of personal independence. However, consumption inevitably involved dependency. Colonists increasingly came to rely upon British merchants, not only for what they sold, but also for a continued supply of credit. ${ }^{173}$

${ }^{170}$ Hugh Williamson, Letter from Sylvious to the Freeman Inhabitants of the United States: Containing Some Remarks on the Scarcity of Money; Paper Currency; National Dress; Foreign Luxuries; the Federal Debt; and Public Taxes (New York: Carroll and Patterson, 1787), n.p.

${ }^{171}$ Mercy Otis Warren, Poems: Dramatic and Miscellaneous (Boston, 1790), 209.

${ }^{172}$ Mercy Otis Warren (1728-1814) was the third of thirteen children born to a Massachusetts family whose lineage reached as far back as the Mayflower. Though Warren received no formal education, she educated herself by sitting in on her brother's childhood lessons and studying alongside him while he attended Harvard. Warren's interest and involvement in politics began early. Her father worked as a lawyer, judge, and colonel of the militia. In 1754, she married James Warren, who would go on to become a member of the Massachusetts legislature. The Warrens hosted meetings at their home in Plymouth for leading opponents of British colonial policies. The meetings were attended by many prominent revolutionary figures, such as John Adams and Samuel Adams. Though Warren had been writing poems since 1759, most published anonymously, her work gained even more attention when she began to write political drams that satirized British representatives in the colonies. Her first play, The Adulateur, appeared in a Boston newspaper in 1772. Well acquainted with many leaders of the Revolution, she urged, unsuccessfully, that equal rights for women be included in the U.S. Constitution, and outlined her objections to the Constitution as originally drafted in Observations on the New Constitution and on the Federal and State Conventions by a Columbian Patriot (1788). See Mercy Otis Warren, Jeffrey H. Richards, and Sharon M. Harris, Mercy Otis Warren: Selected Letters (Athens: The University of Georgia Press, 2009).

${ }^{173}$ T.H. Breen, "Baubles of Britain: The American and Consumer Revolutions of the Eighteenth Century," Past and Present 119 (May, 1988): 101. 
The context in which this coveting took place was one of tensions and hostility. In 1771, the year in which Copley painted Mrs. Gage's portrait, the Sugar Act, the Stamp Act, and the Townshend Acts increased the strain between the colonies and Britain. Colonists were incensed with the trade restrictions and oppressive taxes these laws entailed. Advocates of violent resistance raised voices in protest. Loyalist Ann Hulton repeatedly referred to the Sons of Liberty as the "Sons of Violence" in her letters home and recounted tales of late-night attacks on her house by angry mobs. ${ }^{174}$ In such a charged atmosphere, the donning of English styles cannot be satisfactorily explained as fashion-consciousness alone. Furthermore, not every British fashion was copied in the colonies as repeatedly as turquerie. For example, riding dress was a popular fashion choice in British ladies' portraits, but it was not often adopted in American paintings. ${ }^{175}$ Catherine Sargent (fig. 36) is the sole example in Copley's works. A few other women in fancy dress appear in Copley's works: Ann Tyng as a shepherdess (fig. 23) and Hannah Quincy as Ruben's wife (fig. 37), for instance. However the cluster of women in turquerie painted in the decade preceding the American Revolution demands attention. Just as turquerie struck a chord with stylish masqueraders in England, it resonated with their colonial sisters.

Copley painted several women including Judith Murray (fig. 38), Elizabeth Inman (fig. 39), Catherine Greene (fig. 40), Rebecca Gill (fig. 41), Elizabeth Tyng (fig. 42), and Mercy Scoally (fig. 43), in costumes with a similar motif as Gage's. Their dresses are also loose and open in the front and feature low necklines and full white sleeves. Scoally and Gage lounge in similar poses, but Scoally's gaze boldly meets the viewer's. The other women stand or lean in naturalistic poses helping to accentuate the graceful curves of the fabric that wrap around their

\footnotetext{
${ }^{174}$ Merrill Jensen, The Founding of a Nation: a History of the American Revolution, 1763-1776 (New York: Oxford University Press, 1968), 282.

${ }^{175}$ Ribeiro, Dress in Eighteenth-century Europe, 41.
} 
bodies. Most of the women, like Scoally, Tyng, Gill, Greene, and Gage, wear their hair in loose tresses that, in the case of Scoally, Greene, and Gage, cascade over one of their shoulders. Others, like Inman and Murray, have piled their hair on top of their heads in turban-like mounds. Many of the women have donned strings of pearls, ermine robes, and turbans, adding to the exotic allure of their dress.

The turquerie portraits of Copley combine elements of British art and costume with American elements, such as the women themselves and the interpretation of the costume. However, even as the portraits adopt British forms and styles, they twist that adoption into appropriation and reconfiguration. These portraits can be thought of as "autoethnographic texts." ${ }^{\prime 176}$ As Mary Louise Pratt explains, such texts, often written in a colonial context, selectively appropriate the parlance of the conqueror merged or infiltrated with the indigenousness idioms. ${ }^{177}$ In such texts "people undertake to describe themselves in ways that engage with representations others have made of them." ${ }^{178}$ The purpose of this research is to read these portraits from the perspective of the colonized rather than the colonizer. It is an attempt to decode an appropriated imperial fashion and to acknowledge the potentially subversive character of the portraits.

\footnotetext{
${ }^{176}$ Mary Louise Pratt, “Arts of the Contact Zone," Profession 91 (1991): 37.

${ }^{177}$ Ibid., 34.

${ }^{178}$ Ibid.
} 


\section{CHAPTER 7 \\ Cloth and Clothing in Colonial America}

Before delving into the alternative meanings of turquerie, it is essential to understand how cloth and clothing functioned in late colonial America. For eighteenth-century Americans, clothing was much more than mere protection from the elements or a marker of status. Clothing was political. ${ }^{179}$ As Revolutionary feelings intensified, anti-British protestors organized boycotts of English goods to challenge trade and taxation policies. A broadside directed against one importer, William Jackson, read, "It is desired the Sons and Daughters of Liberty, would not buy any one thing from him, for in so doing they will bring one Disgrace upon themselves, and their Posterity, for ever and ever, AMEN."180 That the broadside is addressed to women as well as men is significant. When an act, as simple choosing where to buy their domestic supplies, was given broad social ramifications, women suddenly had a political role to play. Household actions and objects became politicized, as did women along with them.

For many women, their first political act was spinning. Asked to boycott British textiles, women spun their own cloth, and the wearing of homespun garments became a sign of patriotism. ${ }^{181}$ A December 1769 edition of The Virginia Gazette reported approvingly that nearly one hundred ladies had worn homespun to a recent ball. ${ }^{182}$ The Boston Evening Post and other newspapers gave front page coverage to women's spinning bees. ${ }^{183}$ Spinning, weaving, and knitting are time-consuming, however, and few colonial women, no matter how patriotic,

\footnotetext{
${ }^{179}$ Linda Baumgarten, What Clothes Reveal: The Language of Clothing and Cloth in Colonial and Federal America (Connecticut: Yale University Press, 2002), 6, 74, 87, 99, 102.

${ }^{180}$ The broadside is reproduced in Mary Beth Norton, Liberty's Daughters: The Revolutionary Experience of American Women, 1750-1800 (Boston: Little, Brown and Company, 1980), 158. A notation on the broadside suggests a date of 1771 or 1773 .

${ }^{181}$ Baumgarten, What Clothes Reveal, 105.

182 The Virginia Gazette is quoted in Diana de Marly, Dress in North America: Volume I, The New World, 1492-1800 (New York: Holmes and Meier, 1990): 128.

${ }^{183}$ Norton, Liberty's Daughters, 166-167.
} 
had enough hours to meet all of their families' clothing needs. ${ }^{184}$ But to brand the boycott a failure because of that limitation would be to overlook the powerful symbolism that boycotts conferred to daily tasks. By participating in Boycotts, women were not being asked to move beyond the domestic sphere; their chores remained the same. Furthermore, it would be a mistake to assume that this emerging political activity necessarily granted women a political identity separate from their husbands, fathers, or brothers. Yet, the wearing of homespun reveals an awareness of the politicization of everyday objects and women's growing ability to make political statements through an act as ordinary as a choice in dress.

Once everyday activities became charged with political meaning, an innocent failure to comply could be read as political opposition. As the broadside against Jackson threatened, breaking the boycott would bring disgrace on the purchaser and on their lineage. A woman who did not wear homespun or her oldest silk dress was open to criticism and possible attack. However, fabric and fashion had other implications beyond the registering of protest. Participation in the Revolutionary activity fostered nationalist feelings, a first step in forming a national identity. ${ }^{185}$ Independence from England was essential to both the Revolutionary cause and the process of national self-identification.

In the years immediately following the Revolution, Americans' reliance on British goods, including textiles, continued to lead to a growing national debt that carried with it the mark of political dependence. ${ }^{186}$ Social critics and economists argued that until America was selfsufficient, the country would not truly be independent. In 1787 colonist Hugh Williamson asserted, "For as soon as we can make our own cloaths [sic] and our own arms, we shall be perfectly independent. Surely the man who is cloathed [sic] in American manufacture. . . may be

\footnotetext{
184 Baumgarten, What Clothes Reveal, 109.

185 Norton, 155, 157, 160-161.

186 T.H. Breen, "Baubles of Britain," 87.
} 
allowed to some claims of patriotism, which is the most honourable [sic] garb that can be worn." 187 Williamson advocated the adoption of a national costume that would not only prevent the dependence on foreign textiles, but would also alleviate the influence of English styles on American fashions. ${ }^{188}$ The United States would not only be economically free, but also free from the sense of inferiority that accompanied the copying of British fashions. Although Williamson's suggestion is extreme, it demonstrates how clothing, as it was made, bought, and worn, could be a signifier of the burgeoning nationalism and an assertion of a distinct American identity.

If such an attribution seems too great a symbolic burden to assign to a mere piece of clothing, consider colonist William Eddis's encouragement to British wool producers:

Support that superiority [of wool manufacturing], which the benevolence of heaven has blessed you with, by a judicious and industrious exertion of local advantages, and the power and splendor of Great Britain will defy the utmost efforts of opposition and remain for ages with undiminished luster! ${ }^{189}$

Humble wool, in Eddis's estimation, would shore up the position of the British Empire and stave off revolution. In language strikingly similar to that of the Revolutionaries, British sermonizer James Fordyce urged young English women to buy domestic products: "What sums would be kept at home, that now go abroad to enrich our most dangerous rivals! French geegaws would give place to British manufactures. The ladies of this land, inferior to none in beauty, would be the apes of none in dress." ${ }^{\prime 190}$ In Europe and America, the fabrication and selling of goods became central themes in the discourse of national identity and security. For both the United

${ }^{187}$ T.H. Breen, "An Empire of Goods: The Anglicization of Colonial America, 1690-1776," The Journal of British Studies 25 (October 1986): 476.

${ }^{188}$ Williamson, Letters from Sylvious, 15.

${ }^{189}$ William Eddis, Letters from America (Massachusetts: Applewood Books, 1792), 75.

${ }^{190}$ James Fordyce, Sermons to Young Women (Philadelphia: M. Carey, 1809), 74. 
States and Britain, the manufacture and trade of cloth and clothing became a key weapon in the long battle over dependence and equality.

The symbolic meanings of cloth shifted back and forth during the decade prior to the Revolution. ${ }^{191}$ Because of the colonies' reliance on imports, cloth could be read as a symbol of dependence. At the same time, in donning a style popular in Britain, a colonial woman could be asserting equality in social station with the ladies of London. As Parliament passed taxation legislation and then repealed it, cloth and other commodities became associated with debt, immorality, slavery, and a connection with and membership in the British Empire. ${ }^{192}$ When British imports became associated with dependence and unfair taxation during a boycott, the act of sacrifice in giving them up simultaneously pointed to their desirability. ${ }^{193}$ When the tax was repealed and the boycott lifted, the negative connotations created around those imports could add an illicit tinge to a recently banned purchase. Copley painted women in turquerie throughout this period. Some portraits were made when boycotts were in force, others were not. Rather than reading the turquerie dresses as specifically banned, it is more accurate to read them as politically charged, holding all of the contrasting possible political meanings in some equilibrium that tilted with shifts in the political climate.

\footnotetext{
${ }^{191}$ For a discussion of the social and political arguments behind the boycotts of the 1760 s and 1770 s, see Breen, "Empire of Goods" and "Baubles of Britain".

192 Breen, "Empire of Goods," 497.

193 Breen, "Baubles of Britain," 119.
} 


\section{CHAPTER 8 \\ Pasted Heads and Body Work}

New England society in the mid-eighteenth century had an essential interest in securing the desirable and beautiful material objects of their world. The achievement of worldly success was a sign not of gross avarice, but of divine grace; there was no stigma attached to the possession of material objects. ${ }^{194}$ Copley’s portraiture celebrated his fellow colonials' prosperity, and he did so in a way that was meaningful to them. Copley rendered gleaming mahogany, crystalline water-filled glasses, delicate peach fuzz, iridescent pearls, the sheen of silk, and dense wool jackets. Such skill has caused him to be referred to as the progenitor of American realist painting, and yet Copley was just building upon the lessons of his predecessors. He surrounded his sitters with costumes, fruits, flowers, furniture, and pets they coveted.

Added to Copley's technical proficiency was his keen understanding of the complex protocol of portrait practice. He brilliantly coddled his clients as he painted them, creating not just a portrait, but a diverting and pleasant experience. Copley is now thought of as the chief promoter in America of self-fashioning portraiture, a scholarly term coined for "the interaction between artists and patron to determine the look of a likeness."195 As he moved his studio from location to location, progressively closer to the high-class neighborhood of his clients, Copley devised an ante-room, where his subjects would be shown portfolios of prints, from which they would choose different poses and costumes for Copley to use in the creation of their portraits. ${ }^{196}$

It has been proposed that in mimicking prints, Copley was either emulating his betters, or Copley's patrons were emulating their betters. Copley has also been defended in his sometimes

\footnotetext{
${ }^{194}$ Roy M. Anker, Self-help and Popular Religion in Early American Culture: An Interpretive Guide, (Westport: Greenwood Press, 1999), 87-88.

${ }_{195}$ Rebora-Barratt, John Singleton Copley in America, 16.

${ }^{196}$ Ibid, 16-17 and Rebora-Barratt, "Transforming Colonists.” According to Rebora-Barratt, Copley moved his studio at least three times between 1756 and 1774 .
} 
verbatim replication of mezzotint sources as "practicing" with English forms, using them as "instructional device[s]." ${ }^{\text {197 }}$ However, as seen in his early works done from European prints, such as The Return of Neptune (fig. 9), Copley did not precisely replicate the prints. Instead he changed and altered what he saw to fit his idea of a more pleasing or coherent composition. Therefore, after he had established himself as a professional artist, it was more likely that he borrowed from portrait prints not because he needed "practice" nor because he or his patrons were "nervous provincials" as Staiti and Breen maintain, but because Copley was familiar with artistic practices in London. ${ }^{198}$

Recalling the letter from Reynolds to a prospective portrait patron that concludes, "When the face is finished the rest is done without troubling the sitter," consider the studio practice of this president of the Royal Academy. According to his assistant, Reynolds kept in his studio a portfolio "containing every print that had been taken from his portraits; so that those who came to sit had this collection to look over, and if they fixed on any particular attitude...he would repeat it precisely... as this much facilitated the business, and was sure to please the sitter's fancy." 199 Many English artists followed the same practice displaying not only their own work but prints from others' works as well. ${ }^{200}$ Many artists sent the almost blank canvas with finished head together with the chosen print to a subcontractor, a drapery painter, for completion, or even sent the finished head on a small canvas to be applied to a larger canvas for "body-work" and

${ }^{197}$ Trevor Fairbrother, “John Singleton Copley’s Use of British Mezzotints for his American Portraits: A Reappraisal Prompted by New Discoveries," Arts Magazine 55, no.7 (March 1981): 122-30.

${ }^{198}$ T.H. Breen, "The Meaning of Likeness: The Meaning of Portrait Painting in an Eighteenth Century Consumer Society," Word and Image 6 (October 1990): 346, and Staiti, "Character and Class" in Rebora-Barratt, John Singleton Copley in America, 74.

${ }^{199}$ Sir Joshua Reynolds, Thomas Gray, Charles-Alphonse Dufresnoy, William Mason, The Literary Works of Sir Joshua Reynolds (London: Henry G. Bohn, 1852), 125.

${ }^{200}$ Robin Simon, The Portrait In Britain and America (New York: MacMillian Publishing Company, 1987), 129. 
completion. $^{201}$ These "pasted heads" were not by inferior artists for ignorant patrons but included Allan Ramsay's 1769 portrait of Queen Charlotte and her two eldest sons. Other court portraitists are known to have ready-made bodies onto which faces could be expeditiously appended. $^{202}$ There is little evidence that Copley made use of, or had access to, such services. In a 1768 letter to Benjamin West he complains, "I am obliged to do all parts of my Pictures with my own hand."203 By 1769 through 1770, however, he appears to have begun to make use of the services of his step-brother, as a studio assistant. ${ }^{204}$ While he did not have access to the professional drapery painters of London who were accustomed to copying prints, he certainly had access to and made use of English mezzotints in imitation of artists' practices as much as their dress and postures.

The replicability or plagiarism of portraiture that today is found alarming or amusing in the literary and pictorial practices of "character blanks" and interchangeable portrait bodies did give pause to some, such as a visiting Frenchman in London who commented that "at some distance one might easily mistake a dozen of their portraits for twelve copies of the same original...inspecting the face, you find in all, the same neck, the same arms, the same flesh..."205 Today it is difficult to conceive of this systematic replication of bodies because of the great store society has set on originality in art. However, the practice was common in eighteenth-century Britain. What constituted the successful portrait was the exactitude of the face and, secondly, the appropriateness of pose, context, and costume to gender, life stage, and social station. ${ }^{206}$

${ }^{201}$ John Steegmann, “A Drapery Painter of the Eighteenth Century,” Connoisseur 97, no. 418 (June 1936): $309-15$.

${ }^{202}$ Ibid.

${ }^{203}$ Copley-Pelham Letters, 67.

${ }^{204}$ Ibid., 152, 197, 373.

${ }^{205}$ The Abbé Le Blanc, Letters on the English and French Nations (1747), 159, cited in Lovell, "Copley and the Case of the Blue Dress," 61.

${ }^{206}$ Breen, "The Meaning of Likeness," 347. 


\section{CHAPTER 9}

Tories and Whigs Alike

In eighteenth-century America, there were two recognized ingredients for gentry status: birth and education. ${ }^{207}$ Copley, through his association with Peter Pelham, an English immigrant, came into the circle of those whose business it was to instruct and exhibit the extrinsic aspects of gentry status. Peter Pelham, Jr., Copley's stepfather, taught dance, reading, writing, and painting; Peter Pelham III, Copley's older stepbrother, taught harpsichord, voice, and other musical skills; stepbrother Charles was a tutor and schoolmaster, living with Isaac Royall, one of Copley's earliest patrons. Evidence points to Pelham and his family's interest, expertise, and professionalism in a broad range of arts associated with gentility and civility. Instructing and orchestrating the exhibition of skills of dancing, harpsichord playing and, in portraits, deportment, accomplishment, and costume, Copley and the Pelhams assisted in the realization and demonstration of genteel birth and civil behavior for colonial Americans.

Copley portraits are the records of a synthesis of two distinctly different types of seeing, thinking, and understanding reality; they can be understood as the result of two different types of education. Firstly, there is the observed, those dabs of pigment so carefully mixed and tested and applied in response to visual facts. Second, there is an impressive combination of the observed, the symbolic, the imagined, the synthesized, and the reconstituted. These features are generated out of what is seen and compared to what the conceptual understanding of what must be present to mark an individual as an inhabitant of the portraited social class and to set that individual in relation to others. No enemy to appearances, Copley is unusually deft in the moves he makes in self-presentation and in his writing. It is clear he was an apt pupil of his stepfather's tutelage,

${ }^{207}$ For a discussion on the gentrification of women in eighteenth-century colonial America see Linda Kerber, Women of the Republic: Intellect and Ideology in Revolutionary America (North Carolina: The University of North Carolina Press, 1980). 
receiving a social education most obviously validated by his marriage into the gentry circle but also evident in his early and continued success with his portrait patrons.

As Margaretta Lovell has demonstrated, part of Copley's genius lay in his syncretic ability to combine observed phenomena with appropriate emblems and desired attributes to form a convincing statement of individual and group identity. ${ }^{208} \mathrm{He}$ was masterful at capturing his sitters' desires for certain social personae; in part because he shared those desires. Copley adeptly positioned and presented himself socially yet played a less significant role when discussing the political content of the portraits precisely because he did not share the sitters' political views. ${ }^{209}$ There is no clear evidence to situate him on either side of the American Revolution. A good businessman, he had many reasons to avoid partiality; a declaration one way or the other could result in his loosing half of his business.

The reasons usually given for marking Copley a Loyalist are his ties by marriage to a prominent Loyalist family and his decision to leave the colonies for England in $1774 .^{210}$ However, Copley had been considering a move to England for many years by the time he actually crossed the Atlantic. ${ }^{211}$ Therefore, Copley's decision to go to England may be seen as a professional one, an effort to further his education and to test his artistic mettle in London. His decision was spurred less by political belief than by the difficulty of maintaining a neutral stance among people demanding a clear statement of allegiance. He strove to follow his own advice to

\footnotetext{
${ }^{208}$ Margaretta M. Lovell, Art in a Season of Revolution: Painters, Artisans, and Patrons in Early America (Philadelphia: University of Pennsylvania Press, 2007), 94.

${ }^{209}$ Albert Boime, "Blacks in Shark-Infested Waters: Visual Encodings of Racism in Copley and Homer," Smithsonian Studies in American Art 3 (Winter 1989): 18.

${ }^{210}$ For a detailed description of Susanna (Clarke) Copley's lineage see Prown, John Singleton Copley, 6162.

${ }^{211}$ In 1765 Copley sent his painting The Boy with a Squirrel (1765) to London where it was exhibited. Impressed by the painting, Sir Joshua Reynolds and the expatriate painter Benjamin West urged Copley to immigrate to Europe. In 1774 Copley followed their advice, touring Italy and then settling in London in 1775. See Copley, 45, 54, 68, 116.
} 
his stepbrother, "Be neuter at all events.",212 In a 1779 letter to Benjamin West, Copley

complained, "The Party spirit is so high, that what ever compliments the leaders of either party is looked on as a tassit disappropriation of the other...I am desirous of avoiding every imputation of party spirit." 213 The serious loss of business during a war was no doubt a troubling issue for a man with a growing family. Throughout his career Copley's patrons included families from both sides of the Revolutionary spectrum. Copley's neutrality allowed him the freedom to work with Loyalists and Whigs alike. No other body of his work exemplifies his ability to maintain neutrality better than his turquerie portraits.

In wearing turquerie because of its English origin, the women in Copley's portraits seem to be adopting a stance in support of British rule in the colonies. Yet a consideration of the politics of these women's families reveals a wide range of responses to contemporary political events. $^{214}$ Mary Hooper's (fig. 44) husband, a merchant, was an outspoken Loyalist. ${ }^{215}$ One account has him escaping on a trading ship to Spain during the Revolution, while his wife moved in with her parents in Newburyport, Massachusetts. ${ }^{216}$ Abigail Gardiner (fig. 45) was married to Sylvester Gardiner, a prominent doctor and businessman. ${ }^{217}$ The Gardiners fled to Halifax and then to England during the war. Abigail Babcock (fig. 46) was married to Adam Babcock, a merchant who supported the Revolution and supplied the colonial armies with rice, bales of

${ }^{212}$ Ibid., 343.

213 Copley-Pelham Letters, 98.

${ }^{214}$ To link each of these women so directly to her husband's political opinions may confound today's reader. However it would be historically inaccurate to ignore the social and legal ties that bound these women to the views of their husbands.

${ }^{215}$ James Henry Stark, The Loyalists of Massachusetts and The Other Side of the American Revolution (Boston: James H. Stark, 1910), 223.

${ }^{216}$ Ibid. It must be noted that some women remained in the colonies when their husbands fled in order to prevent property and land from being seized by the Revolutionary forces. Mary Hooper may have been performing this task.

${ }^{217}$ Ibid, 313-315. 
wool, and suits of clothes. ${ }^{218}$ Martha Lee's (fig. 34) husband was a radical Whig who organized opposition to the Stamp Act. ${ }^{219}$ He was elected to serve the town of Marblehead at the Continental Congress in 1774 but instead took a seat in the provincial congress. ${ }^{220}$ Mercy Scoally's (fig. 43) husband was a Son of Liberty who signed a petition sent to King George III protesting the illegal actions of British revenue officers. ${ }^{221}$ The political sympathies of the Elizabeth Ross Tyng (fig. 42) family are unknown, although it might be significant that her father opposed her marriage to William Tyng who became a Loyalist, preferring a match with John Hancock. ${ }^{222}$ It is not surprising to find such a diversely opinionated group in colonies that are approaching a break from their parent. That all of these women chose to wear turquerie for their portraits demonstrates the symbolic and ideological richness of the costume.

${ }^{218}$ Barbara Neville Parker and Ann Bolling Wheeler, John Singleton Copley: American portraits in oil, pastel, and miniature (Boston: Museum of Fine Arts, 1938), 30-31.

${ }^{219}$ Ibid., 124.

${ }^{220}$ Ibid., 123.

${ }^{221}$ David Kruh, Always Something Doing: Boston's Infamous Scoally Square (Chicago: Northeastern University Press, 1989 ), 12.

${ }^{222}$ Neville and Wheeler, John Singleton Copley, 165. 


\section{CHAPTER 10}

\section{To Break Away from Rigid Confinements}

A costume divorces its wearer from the actuality of her daily life, symbolically infusing her with its correlated conventions. An ambiguous or imagined setting completes the process. Dressed in turquerie and with only a sofa to locate her in eighteenth-century Britain or one of its colonies, Margaret Gage occupies an uncertain space removed from her usual surroundings, appearance, and responsibilities as mother, household keeper, and wife. The dress particularly serves to relegate Gage to a secluded space cloaked in fantasy. Unlike her British counterparts who wore such dresses to masquerades, American women, such as Gage, would have had no occasion to wear such a dress outside of Copley's studio because masquerades were unheard of in the colonies. ${ }^{223}$ By donning a turquerie costume, Margaret Gage allowed herself to become imbued with the associated characteristics of the Orient. Wearing turquerie removed Mrs. Gage from 1770's America, and triggered an important set of meanings and identifications, those of orientalism.

Edward Said defines orientalism as "a certain will or intention to understand, in some cases to control, manipulate, even to incorporate, what is a manifestly different world." ${ }^{224} \mathrm{He}$ emphasizes that orientalism's ultimate concern is with "the idea of Europe" and the identification of Europe as different from and superior to all non-European nations. ${ }^{225}$ While orientalism may be a "will to understand," the accuracy of what is understood is not relevant, only that it is understood to the satisfaction of the European. ${ }^{226}$ The subsummation of an American woman's identity by Turkish costume does not result in the temporary dominance of Turkish culture.

\footnotetext{
${ }^{223}$ Rebora-Barratt, Turkish Fashion in $18^{\text {th }}$-Century America, 39.

${ }^{224}$ Said, Orientalism, 12.

${ }^{225}$ Ibid., 7.

${ }^{226}$ Ibid., 267.
} 
Rather it is the Western wearer and the Western viewer's interpretation, however correct or incorrect it may be that controls how the costume is read.

Power is a central component of orientalism, but power is not limited to political control. Said also identifies an exchange of intellectual, cultural, and moral power. Art historian Perrin Stein has argued that Said's definition of orientalism ignores crucial differences between the eighteenth and nineteenth centuries. She suggests that the interest in the exotic "other" and territorial expansion that characterized later orientalism was not as important as the allegorical functions of orientalism in regards to gender and class in eighteenth-century society. ${ }^{227}$ Eighteenth-century Europeans, for example, used the harem to symbolize the ability of the patriarchal order to control women. ${ }^{228}$ Stein's example shows that whether orientalism involved the actual subjugation of a people or if orientalist elements were borrowed to illustrate symbolically a subjugation of a class or gender, either way, power is a key issue. Therefore, as the image of the harem implies, sexual power should be added to Said's list.

Eighteenth-century Europeans strongly associated the Orient with sensuality and sexual licentiousness. $^{229}$ For example, a sermon Fordyce wrote on dress drew upon the third chapter of Isaiah when God punished "the pride and wantonness of those eastern females." ${ }^{230}$ A lengthy section lists all the articles of clothing that offended God, including "the bravery of their tinkering ornaments, nose-jewels, mantles, and changeable clothes." 231 Hannah More, another British religious writer who was popular in the colonies, also singled out the Orient in her sermon An Estimate of the Religion of the Fashionable World. More wondered if a stranger, set down in London, could guess which religion the denizens of the fashionable world practiced.

${ }^{227}$ Stein, "The French Sultana," 432.

${ }^{228}$ Ibid., 433.

${ }^{229}$ Breskin, "On the Periphery of a Greater World," 117.

${ }^{230}$ Fordyce, Sermons to Young Women, 56-57.

${ }^{231}$ Ibid. 
She surmised that the stranger would settle upon the "Mahometan" (Islamic) faith. ${ }^{232}$ However, despite its risqué reputation, or because of it, turquerie was a popular costume in Britain thanks in large part to the vivid accounts of Lady Montagu's experiences in Turkey.

Montagu's letters contain numerous allusions to the rich, sensual life in a seraglio. ${ }^{233}$ She describes in detail the beauty of the women, the heavy scent of perfume, the "convenient and easy" low couches covered with thick rugs and fat pillows, the play of water in the fountains. ${ }^{234}$

On one visit, four young women are commanded to dance for her. Afterward she confided,

Nothing could be more artful or proper to raise certain ideas; the tunes so soft, the motions so languishing, accompanied with pauses and dying eyes, half falling back and then recovering themselves in so artful a manner that I am very positive the coldest and most rigid prude upon earth could not have looked upon them without thinking of something not to be spoken of. ${ }^{235}$

In this instance, Montagu acknowledges and even participates in the charged, erotic atmosphere.

On a visit to the Turkish baths, however, she maintained a careful distinction between herself and the Turkish women, remaining steadfastly clothed while admiring the beauty of the naked women around her. When the Turkish women urged her to undress, she showed them her corset. "I saw they believed I was so locked up in that machine, that it was not in my own power to open it, which they attributed to my husband."236 Lady Montagu allowed her Turkish friends to believe that her husband had locked her "in that machine.",237

When considering Margaret Gage's portrait, General Gage can be seen as the controlling figure behind his wife's portrait since it is his money that paid for the painting. ${ }^{238}$ Therefore, he

${ }^{232}$ Hannah More, Works of Hannah More, "An Estimate of the Religion of the Fashionable World" (New York: Harper and Bothers Publishers, 1793), 131.

${ }^{233}$ According to Stein, a seraglio (also serraglio) is the sequestered living quarters used by wives and concubines in a Turkish household. The term harem is also used to refer to these sequestered living quarters, but has additionally come to refer to the women themselves.

${ }^{234}$ Montagu, The Letters and Works, 312.

${ }^{235}$ Ibid., 319.

${ }^{236}$ Ibid., 286.

${ }^{237}$ Ibid.

${ }^{238}$ Isabel Breskin, "On the Periphery of a Greater World," 119. 
permitted his wife to shed her bonds to be portrayed seemingly uncorseted. In her portrait, Mrs. Gage rests on that "easy and convenient" sofa. Her heavy-lidded, dark gaze may suggest "dying eyes" and helps to create a dreamy, even sultry aura. The sensual connotations of turquerie could create the impression that a women who wore it for her portrait was sexually available. ${ }^{239}$ It became possible, even appropriate, to think of her in terms of being sexually dominated. ${ }^{240}$

As Marcia Pointon has maintained, in colonial discourse the Oriental women represented a feminized, sexualized colonial nation. "Women in this discourse can function as a metaphor for the degeneration of the violated nation while simultaneously standing as a sign of the conqueror."241 Therefore, Mrs. Gage in her portrait could represent a connection not only to Britain but also to the American colonies as controlled and incorporated by Britain. With his wife clad in Turkish costume, General Gage could assert himself as a Western and specifically an imperialist identity. He could claim his wife's submission to him and his cause, even as she may have withheld it. By apparently shedding her corset and donning Turkish costume, Mrs. Gage could be seen as participating in a specifically masculine agenda.

Margaret Gage's example shows a blurring of distinction between submission to husband and submission to colonizing power. In reality, the position of married women in eighteenthcentury America has striking parallels to the position of a colonized nation. A married woman lost her legal and social position as an individual under the laws of coverture. She became a femme couvert "covered" by her husband. ${ }^{242}$ Any land or property she owned became his; she had neither the right to sell it nor to prevent him from selling it. ${ }^{243}$ She became politically

\footnotetext{
${ }^{239}$ Ibid., 119.

${ }^{240}$ Ibid., 118.

${ }^{241}$ Marcia R. Pointon, Hanging the Head: Portraiture and Social Formation in Eighteenth-Century England (New Haven: Yale University Press, 1993): 149-51.

${ }_{242}$ Bruce H. Mann and Christopher L. Tomlins, The Many Legalities of Early America (Chapel Hill: University of North Carolina Press, 2001), 289.

${ }^{243}$ Ibid., 383.
} 
invisible as her identity was subsumed by his. ${ }^{244}$ Coverture was based on the assumption that a married woman had neither an independent mind nor independent power. ${ }^{245}$ According to Linda Kerber, "By inhibiting the independent manipulations of property, the laws of coverture reinforced political weakness and were used to justify other elements of the legal system that did the same."246 Coverture became a means for men to continuously reassert their dominant position and to deny women any autonomy.

Elizabeth Fergusson, a wealthy American heiress, became estranged from her penniless, Scottish husband because they had a "Difference of Political Opinion." 247 After the war all her property was confiscated even though her marriage was over; her husband had failed to return to Philadelphia after fleeing back to Scotland. Under the laws of coverture, the property was his, and he was a Loyalist. In the midst of her long battle to have her property returned, she described her troubles:

Deem woman made alone for man's control, Like Mahomets fair ones void of noble soul.

As Birds or Insects for a Boy to please, They tortured Subjects made [for] their Lords to teize. ${ }^{248}$

Fergusson compares herself to a woman in a harem, kept at and for her lord's pleasure. She uses the harem to allegorize her situation as a femme couvert. Her poem reveals the pervasiveness of oriental imagery and its perceived relevance to the contemporary condition of women. In the tense atmosphere of the late 1760s and early 1770s, the portraits of women in turquerie can be interpreted as justification for domination, an imperialist domination and a domination based on gender.

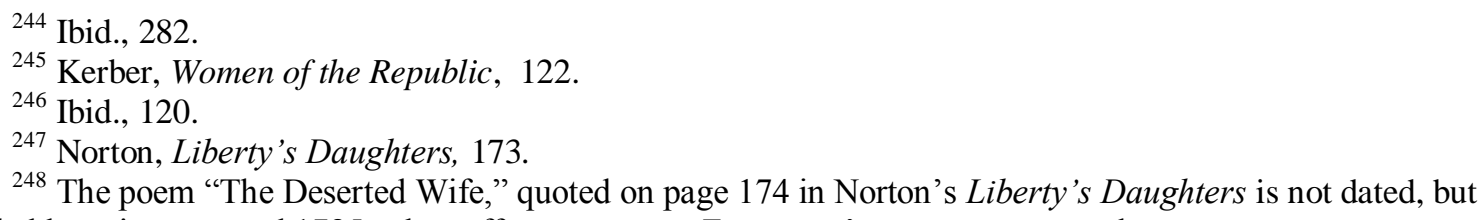
was probably written around 1785, when efforts to restore Fergusson's property occurred. 
Coverture was an ever-present fact in the lives of colonial women. It had followed the first brave women to America's shores from Europe and continued to regiment their lives for centuries thereafter. ${ }^{249}$ However, women who lived in the early colonies found themselves in a place where the old, European gender rules had been, if not abolished, at least temporarily suspended due to living conditions. During these primitive years in the colonies, almost everyone lived on a farm, the idea behind the colonial dream was to own land and grow a profitable cash crop. ${ }^{250}$ The English believed fieldwork was a man's task, but the colonies were desperately short on labor, therefore young planters expected their wives to labor alongside them in the fields. ${ }^{251}$ The farms were isolated, surrounded by endless forests, down winding waterways without any real roads to connect them. ${ }^{252}$ Men were often forced to be away from home for long periods of time on business, and they often depended on their wives, or even daughters, to manage things while they were gone. ${ }^{253}$ The dissolution of the normal boundaries between women's work and men's allowed women to operate with an independence the nation would never see again until the twentieth century.

Although women were not supposed to hold positions that properly belonged to the head of the household, they frequently did the work anyway. Many businesses that were theoretically operated by men were actually conducted by their wives while they were at sea, or travelling, or engaged in some other commercial pursuit. ${ }^{254}$ In these instances the laws of coverture were bent,

${ }^{249}$ Joan Hoff, "American Women and the Lingering Implications of Coverture," The Social Science Journal 44, no. 1 (2007): 41-55. In her article, Hoff chronicles the development of legalities meant to modify an American legal system that since its inception had prevented women from acting as their own legal agents. She marks the Married Women Property Acts as examples of such remedies. However, she points out that even with the advent of contractual marriages in the 1970s and 1980s, coverture undertones in these laws still exist.

${ }^{250}$ Lois G. Carr and Lorena S. Walsh, "The Planter's Wife: The Experience of White Women in Seventeenth-Century Maryland," The William and Mary Quarterly 34 (October, 1977): 542.

${ }^{251}$ Ibid., 564.

${ }^{252}$ Ibid., 570.

${ }^{253}$ Ibid., 567.

${ }^{254}$ Alice Morse Earl, Home Life in Colonial Days (Stockbridge, Mass.: Berkshire House, 1993), 47. 
not to make women more independent, but to protect husbands' properties, and also to protect creditors in case the travelling husbands abandoned their families. ${ }^{255}$ For example Pennsylvania gave women who were left in charge of their husbands' businesses the right to establish credit, sue, and sign contracts. ${ }^{256}$ In Massachusetts Copley’s own mother took over the family tobacco business when her husband died suddenly. Perhaps as evidence of the appreciation of the independence she experienced by being an entrepreneur, even after she was married to Peter Pelham, Copley's mother continued to operate her business. ${ }^{257}$ These wives were accepted as merchants, farmers, printers, or store managers. ${ }^{258}$ A few jobs, like tavern- and inn-keeping, were seen as a natural extension of a housewife's hospitality. ${ }^{259}$

The rough and raw era of early colonial settlement had faded by the beginning of the eighteenth century. The male-female sex ratio was beginning to even out. ${ }^{260}$ People were no longer dying off as quickly as they had been in the earlier years of inhabiting the New World. ${ }^{261}$ Families were less likely to be the collection of offspring from widows' and widowers' former marriages. ${ }^{262}$ Men had male relatives they could rely on to handle their estates in case they died, as well as lawyers to take care of businesses in their absence. ${ }^{263}$ In many parts of the colonies life was becoming more civilized, and in many ways, things were getting easier. Families could acquire bolts of cloth from the nearest store, freeing housewives from the tyranny of the spinning

${ }^{255}$ Mann and Tomlins, 383.

${ }^{256}$ Ibid., 384.

${ }^{257}$ For a discussion on Mary Pelham's marriages and business practices see page 9.

${ }^{258}$ Ibid., 384-85.

259 Jeanne Boydston, Home and Work: Housework, Wages, and Ideology of Labor in the Early Republic (New York: Oxford University Press, 1990), 23.

${ }^{260}$ Mary Beth Norton, Founding Mothers and Fathers: Gendered Power and the Forming of American Society (New York: A.A. Knopf, 2002), 13.

${ }^{261}$ Ibid., 147.

${ }^{262}$ Ibid., 148.

${ }^{263}$ Ibid., 139. 
wheel. ${ }^{264}$ Everyday necessities like candles and soap, which had to be manufactured at home in the seventeenth century, could be purchased in the eighteenth. ${ }^{265}$ American women may have regarded this as a definite improvement, but the change also seems to have contributed to a slippage in their status. The housewife's contribution to her family started to be described in terms of emotional support, not the type of economic partnership women of the early colonies had experienced. ${ }^{266}$ Most women actually performed as much labor as they had a generation earlier. Although they may have done less spinning, higher standards of cleanliness dictated that they do much more washing and sweeping, and polishing. ${ }^{267}$ On the farms, instead of planting flax that their wives turned into linen, men planted cash crops that they sold, and bought cloth with the profit. ${ }^{268}$ By the time Copley painted Margaret Gage's portrait in 1771, the position of women in the colonies seems to have been pushed to the fringes. One of the era's most quoted letters was written by Abigail Adams to her husband when the Continental Congress was meeting to draw up the Declaration on Independence:

In the new Code of Laws which I suppose it will be necessary for you to make I desire you would Remember the Ladies, and be more generous and favorable to them than your ancestors. Do not put such unlimited power into the hands of the Husbands. . . That your Sex are Naturally

Tyrannical is a Truth so thoroughly established as to admit of no dispute, but such of you as wish to be happy willingly give up the title of Master for the more tender and endearing one of Friend. Why then, not put it out of the power of the vicious and the Lawless to use us with cruelty and indignity and impunity. Men of Sense in all Ages abhor those customs which treat us only as vassals of your Sex. ${ }^{269}$

\footnotetext{
${ }^{264}$ Earle, Home Life, 16.

265 Ibid., 17.

${ }^{266}$ Ruth Bloch, "American Feminine Ideals in Transition: The Rise of the Moral Mother," Feminist Studies
} 4, no. 2 (June 1978): 102.

${ }^{267}$ Claudia Bushman and Richard Bushman, "The Early History of Cleanliness in America," Journal of American History 74, no. 4 (March 1988): 1214.

${ }^{268}$ Boydston, 18.

${ }^{269}$ L.H. Butterfield, Marc Friedlaender, and Mary-Jo Kline, eds., The Book of Abigail and John: Selected Letters of the Adams Family, 1762-1784 (Cambridge, Mass.: Harvard University Press, 1975): 107-108. 
Adams's response, which is less well known, wounded his wife deeply, "As to your extraordinary code of laws," he wrote, "I cannot but laugh."270

At issue was the loss of independence through socially sanctioned and legally justified structures. These structures robbed the individual entity, be it a woman or a colony, of rights as well as the opportunity to construct an identity. Societal and legal systems formulated the married woman's social, economic, and political identity for her, and then only in relation to her husband. ${ }^{271}$ A colony's official identity was similarly determined by the ruling nation's understanding of its colony, which may or may not be accurate. In both cases, self-definition is denied. As the women dressed in turquerie temporarily lose their identity in their costume, they are representing a more permanent loss of independent legal and political identity through marriage and the repression of a developing American national identity.

Fiction becomes implicated in the process of asserting identity. In the eighteenth century, the creation of alternate fictional selves could be achieved through costume as well as through the newly emerging novel. Novels, particularly sentimental ones, provided women with stories written about them, for them, and often by them. Scholars have described the intense criticism leveled at novels: they would keep a woman from her wifely duties, they were indulgent and unimproving, and they fostered romantic notions and encouraged illicit behavior. They challenged the existing social order and called male authority into question. ${ }^{272}$ Reading was an expression of a woman's individual choice in what she read and how she responded. The effort to control reading was an effort to keep a woman's mind and body available to her husband and unavailable to other men, real or fictional. In other words, a woman engrossed in a book was a

\footnotetext{
${ }^{270}$ Ibid., 108.

${ }^{271}$ Mann and Tomlins, Many Legalities, 282-283. And Kerber, Women of the Republic, 120-135.

272 Cathy N. Davidson, Revolution and the Word: The Rise of the Novel in America (New York: Oxford University Press, 1986), 46; Kerber, Women of the Republic, 241.
} 
woman seduced. Controlling women's reading was an attempt to control their sexuality. ${ }^{273}$

Turquerie created an aura of licentiousness around a woman that could be interpreted as an invitation to sexual domination. It also, however, created a sexual threat; that of the promiscuous woman acting on her emotions and flouting her role as wife. ${ }^{274}$ Both the fictional novel and the characters in those novels potentially created passionate, self-willed women.

In response to such a threat, only certain books were deemed appropriate for American women: the classics translated into English, works of history, and the Bible. ${ }^{275}$ However, there were dangers associated with even the approved reading. While a novel might lead to an excess of female passion, the over-development of a woman's intellect could result in a loss of her feminine qualities, masculinizing her. Women were warned against taxing their minds, which would spoil their health and their looks, and showing their knowledge in male company. In his widely read Father's Legacy to His Daughters (1774), John Gregory warned,
Be ever cautious in displaying your good sense... it will be thought you assume a superiority over the rest of the company. But if you happen to have learning, keep it a profound secret, especially from men, who generally look with a jealous and malignant eye on a woman with...a cultured understanding. ${ }^{276}$

Even Montagu urged her granddaughters to hide their learning as if it were a physical deformity. ${ }^{277}$ An essential part of a genteel woman's character, therefore, was disguise. She must veil her intellect, hiding knowledge and good sense behind a costume of helplessness and dependence.

Donning a costume could also represent a moment of ritualistic self-fictionalization when the self was reconstructed or reimagined to appropriate certain chosen characteristics. In her

\footnotetext{
${ }^{273}$ Davidson, Revolution, 46-47.

${ }^{274}$ Breskin, 122.

275 Hayes, Colonial Woman's Bookshelf, 5, 6, 29, 61.

276 John Gregory, A Father's Legacy to His Daughters (Paris: F. Louis, 1819): 15. For the popularity of this book see Hayes, Colonial Woman's Bookshelf, 78-79.

${ }^{277}$ Montagu, Letters and Works, 45.
} 
introduction to Lady Montagu's Turkish Embassy Letters, Anita Desai suggests that traveling in the Orient allowed Montagu "to break away from the rigid confinements, mental and intellectual as much as physical, of her own society." ${ }^{278}$ The Orient could therefore function as a space in which customary, European societal norms fell away and were replaced by attitudes and activities of the individual's choosing. In Montagu's letter, femininity brings special privileges, access, and opportunity. On several occasions she contrasts her knowledge of harem life to travel accounts written by men. "They never fail to give you an account," she ridicules, "of the women, which 'tis certain they never saw." ${ }^{279}$ Her gender allows her access to the harems while "'Tis no less than death for a man to be found in one of these places." 280

In another letter, Montagu praises Turkish women's practice of keeping their money in their own hands and concludes, "On the whole, I look upon the Turkish women as the only free people in the empire. ${ }^{281}$ Freedom here is specifically linked with financial independence, and, an implicit contrast is drawn to the English and American laws of coverture. Montagu even finds her veil liberating, for it gives women "entire liberty of following their inclinations without danger of discovery." $282 \quad$ A veil allowed Montagu to slip through the streets of Turkey unrecognized, but the colonial woman's disguise did not grant her such freedoms. While it hid her intellect, it left her face and name uncovered. Colonial American women who read Montagu's letters might symbolically appropriate the Turkish women's purported financial and sexual freedoms by donning turquerie. For western women with no opportunity to wear a veil, such a refiguration could only occur symbolically. The costume represented not only a

\footnotetext{
${ }^{278}$ Anita Desai, "Introduction," in Montagu, Turkish Embassy Letters (London: Pickering and Chatto, 1994), xxvi.

${ }^{279}$ Montagu, The Letters and Works, 104.

${ }^{280}$ Ibid, 60 .

${ }^{281}$ Ibid., 72.

${ }^{282}$ Ibid., 71.
} 
temporary fictionalization of self but one that perhaps offered some relief from the strictures that Fergusson lamented in her poem; it perhaps even registered a quiet protest. 


\section{CHAPTER 11}

\section{A Masterful Union}

It is hard to imagine what it must have been like to have been Margaret Gage stepping into Copley's studio for the first time. Mrs. Gage had signed on for three portraits, two halflengths and one bust. ${ }^{283}$ Her visit may have begun with a conversation in the artist's anteroom, where there would have no doubt been an in-depth conversation about poses, costumes, hairstyles, and attitudes. He may have shown her and her companions, if she had brought anyone along, a portfolio of prints after English portraits. ${ }^{284}$ Copley's turquerie portrait of Margaret Gage is a synthesis of two very different ways of seeing, thinking, and understanding truth. To begin with there is the visually perceived, the paint so carefully mixed and meticulously applied to match empirical facts. Alternatively, there is a combination of the symbolic, the imagined, the synthesized, and the altered to make up what must be present in a portrait to mark Mrs. Gage as part of the gentile social class.

According to Carrie Rebora-Barratt, Mrs. Gage’s portrait may ultimately derive from Kneller's portrait of Lady Mary Wortley Montagu (1719-20), which was engraved by Caroline Watson (fig. 47). ${ }^{285}$ On her camelback sofa, Margaret Gage plays her role more thinly than do Lady Mary Montagu; Mary Gunning, Countess of Coventry (fig. 31); or Empress Marie Adelaide (fig. 32), portrayed by Kneller and Liotard respectively in elaborate Turkish costumes on soft, low sofas reminiscent of harem furniture. Yet Mrs. Gage shares with these British women a daringly casual pose and a strikingly nonchalant attitude.

Lisa Lowe has described how Lady Montagu identified with veiled Turkish women as women, even as she differentiated herself from other aspects of Turkish life to reaffirm

\footnotetext{
${ }^{283}$ Copley-Pelham Letters, 120. Two of these portraits are lost.

${ }^{284}$ For a discussion about Copley's studio and artistic practices see pages 25-29.

${ }^{285}$ Rebora-Barratt, Turkish Fashion in Eighteenth-Century America, 15.
} 
understood hierarchies of Occident and Orient. ${ }^{286}$ Lowe discusses the "plurality and mutability" of an orientalist situation that allows this simultaneous identification and differentiation, as an individual's gender, class, and culture determine how the situation is read. ${ }^{287}$ The patterns of identification and differentiation become more intricate as one imagines an American colonial woman reading Montagu's letters. This mutable and transformative process occurs just as persistently when one tries to read the turquerie costume that Margaret Gage wears in her portrait. As the wife of a British officer, Mrs. Gage, may have felt a sense of kinship with Lady Montagu. ${ }^{288}$ As a femme couvert she may have envied a Turkish woman's supposed liberties. As an American colonial, she may have welcomed the implicit superiority granted to the West, or she may have baulked at the distinction between powerful Britain and the powerless colonies.

In colonial America, the social position of a married woman had striking similarities to the position of a colonized nation. ${ }^{289}$ At issue was the loss of independence through legal and socially accepted structures. These structures robbed individual women of their identity as well as their social, economic, and political rights. A married woman lost her legal and social position as an individual under the laws of coverture. ${ }^{290}$ She became a femme couvert. She became politically invisible as her identity was subsumed by her husband's. In such an atmosphere, a woman had to veil her intellect, hiding knowledge and good sense behind a costume of helplessness and dependence at the risk of socially losing her femininity and public status. ${ }^{291}$ Therefore, an essential part of a refined woman's character became disguise. As the

\footnotetext{
${ }^{286}$ Lowe, Critical Terrains: French and British Orientalisms (Ithaca: Cornell University Press, 1991), 32. ${ }^{287}$ Ibid, 25-36.

${ }^{288}$ For information about the marriage of General and Mrs. Gage or her responsibilities as wife and mother

${ }^{289}$ For the importation of British goods and fashions in colonial America and the financial dependence this created in the colonies see pages 41-42. For the effect of revolutionary feelings on cloth and clothing in colonial

${ }^{290}$ Information about the laws of coverture in the American Colonies can be found on pages 61-64.

${ }^{291}$ For a discussion about female literacy, knowledge and social appearances see page 65.
} see pages $10-12$. America see pages 45-48. 
turquerie costume in Margaret Gage's portrait inscribes more and more deeply the role of women as femme couvert, as veiled intellectuals and subjugated colonials, it also manages to raise a note of defiance. After all, Margaret Gage is, for this created moment, among the "only free people in the empire." 


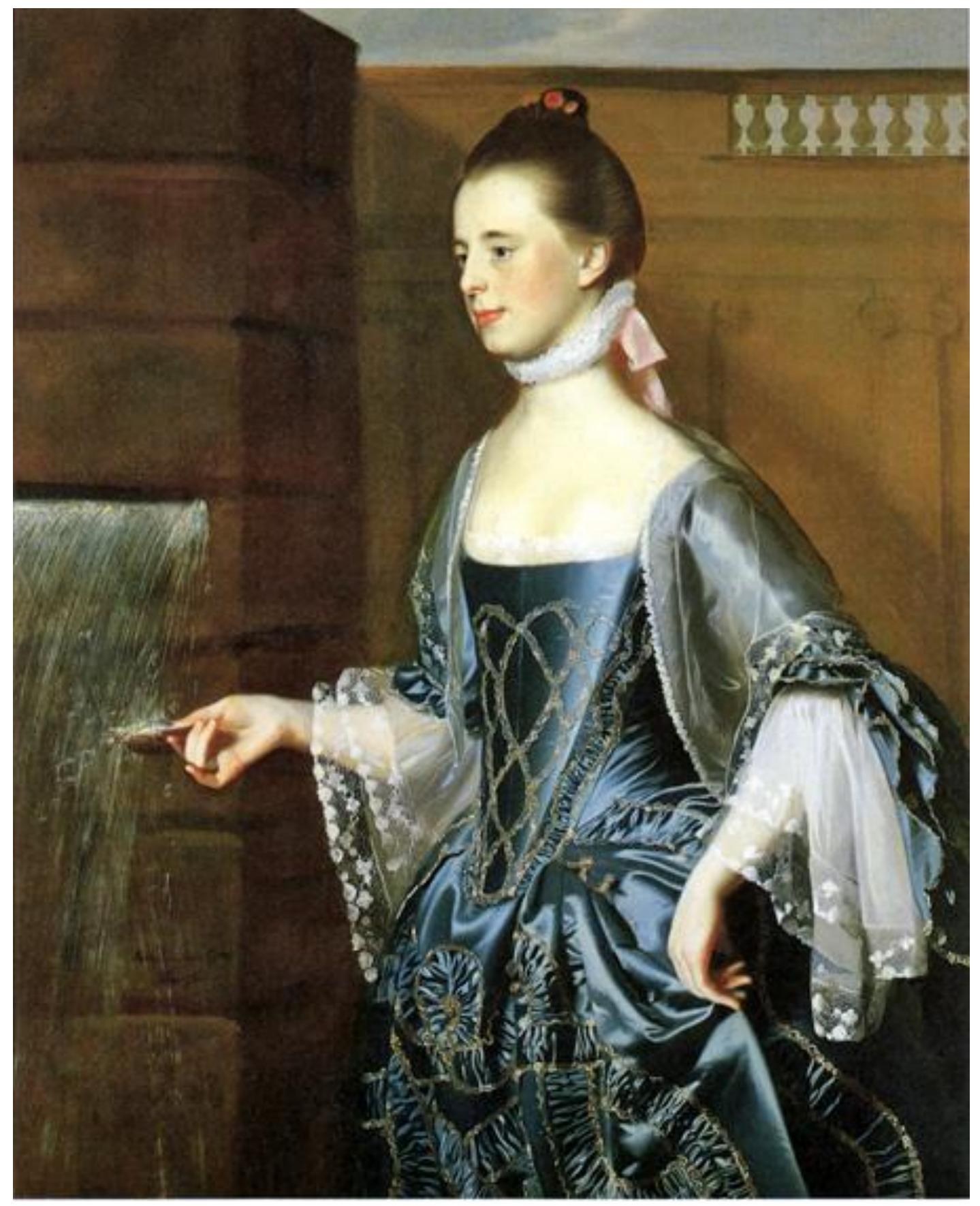

Figure 1. John Singleton Copley, Mary Turner Sargent (Mrs. Daniel Sargent), 1763. Oil on canvas, 49 1/2 x 39 1/4 in, Fine Arts Museums of San Francisco, de Young Museum. 


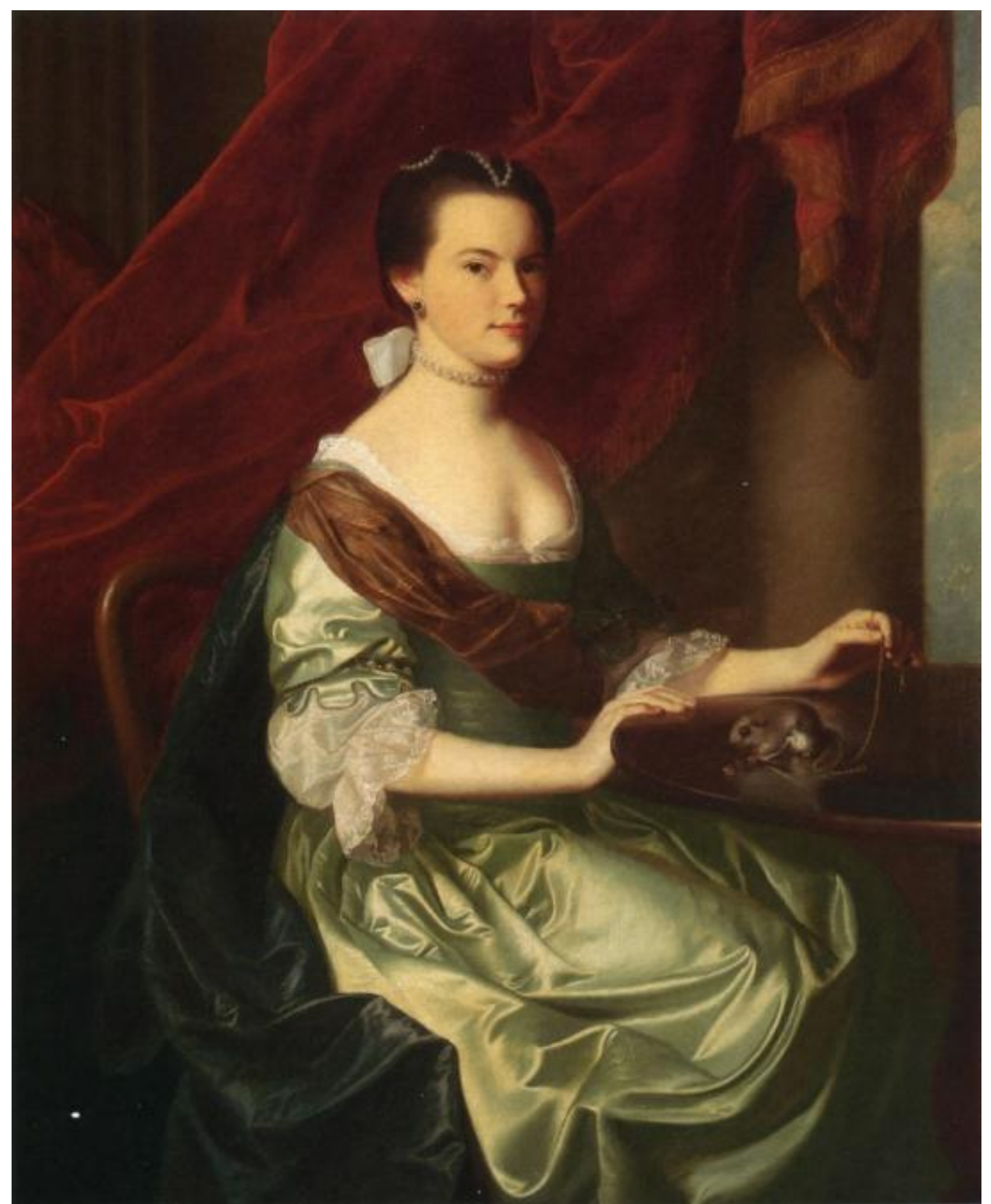

Figure 2. John Singleton Copley, Francis Atkinson (Mrs. Theodore Atkinson, Jr.), 1765. Oil on canvas, 51 x 40 in, Private Collection. 


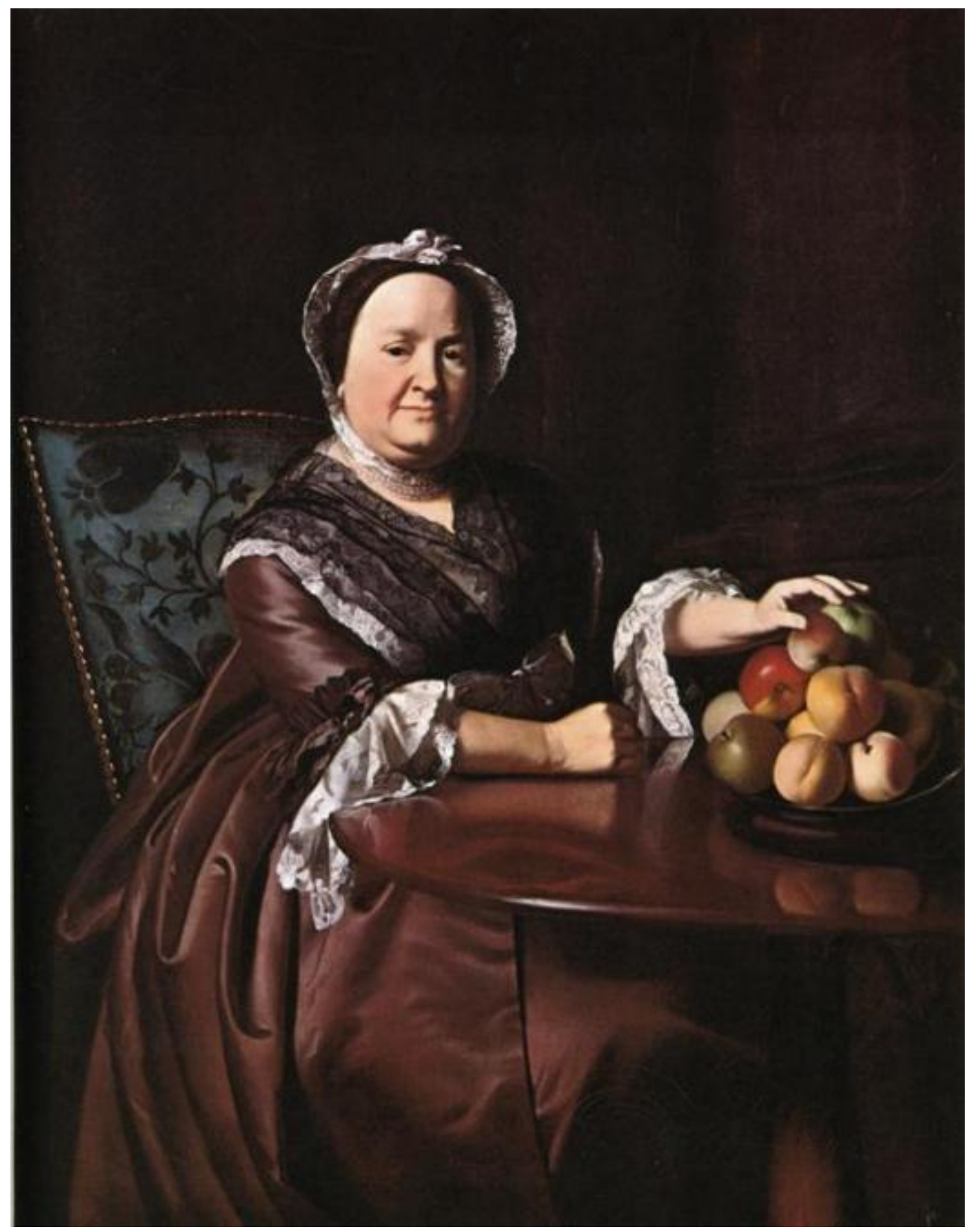

Figure 3. John Singleton Copley, Elizabeth Lewis Goldthwait (Mrs. Ezekiel Goldthwait), 1771. Oil on canvas, 50 1/8 x 40 1/8 in, The Museum of Fine Arts, Boston. 


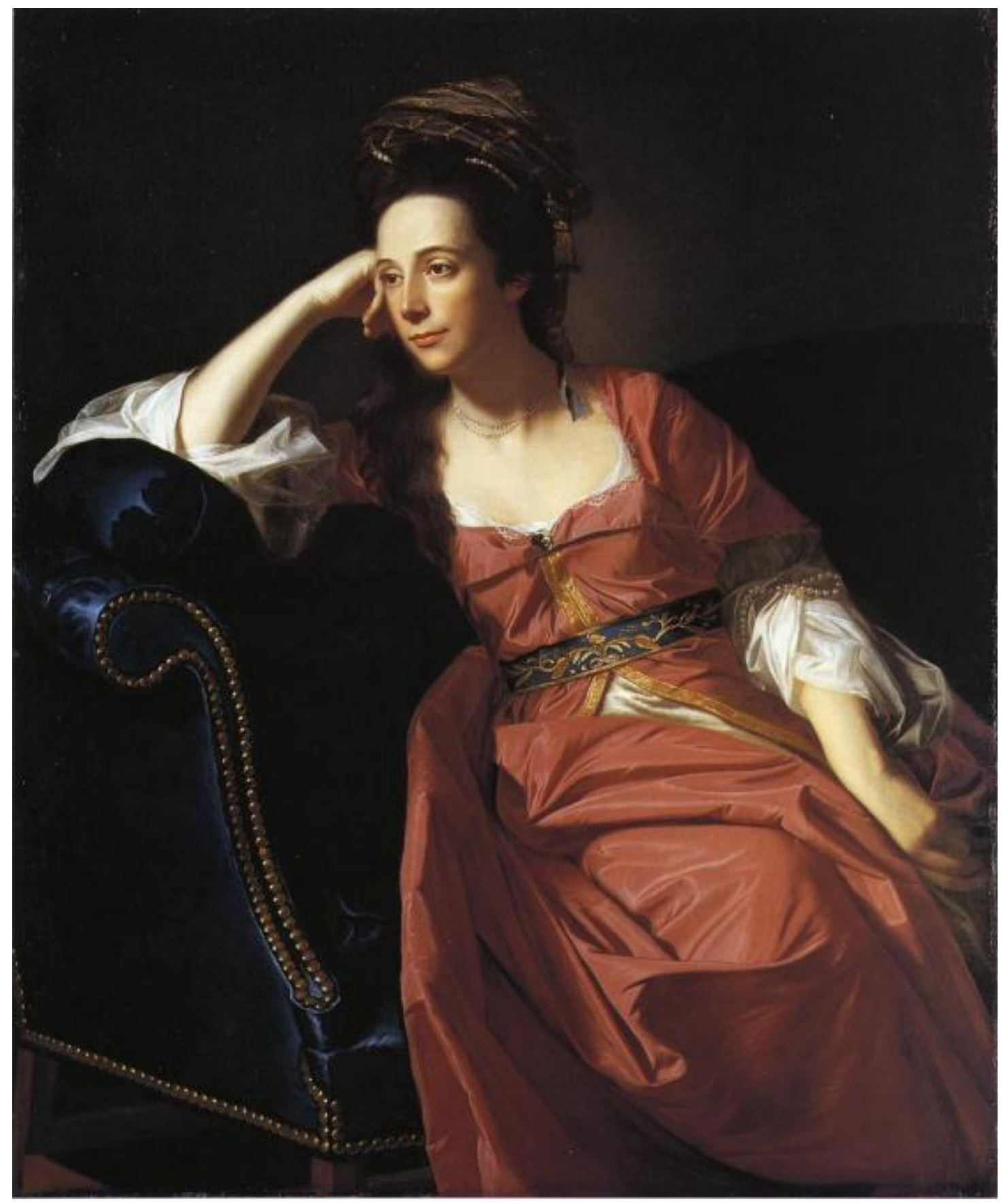

Figure 4. John Singleton Copley, Margaret Kemble Gage (Mrs. Thomas Gage), 1771. Oil on canvas, 50 x 40 in., The Timken Museum of Art, San Diego. 


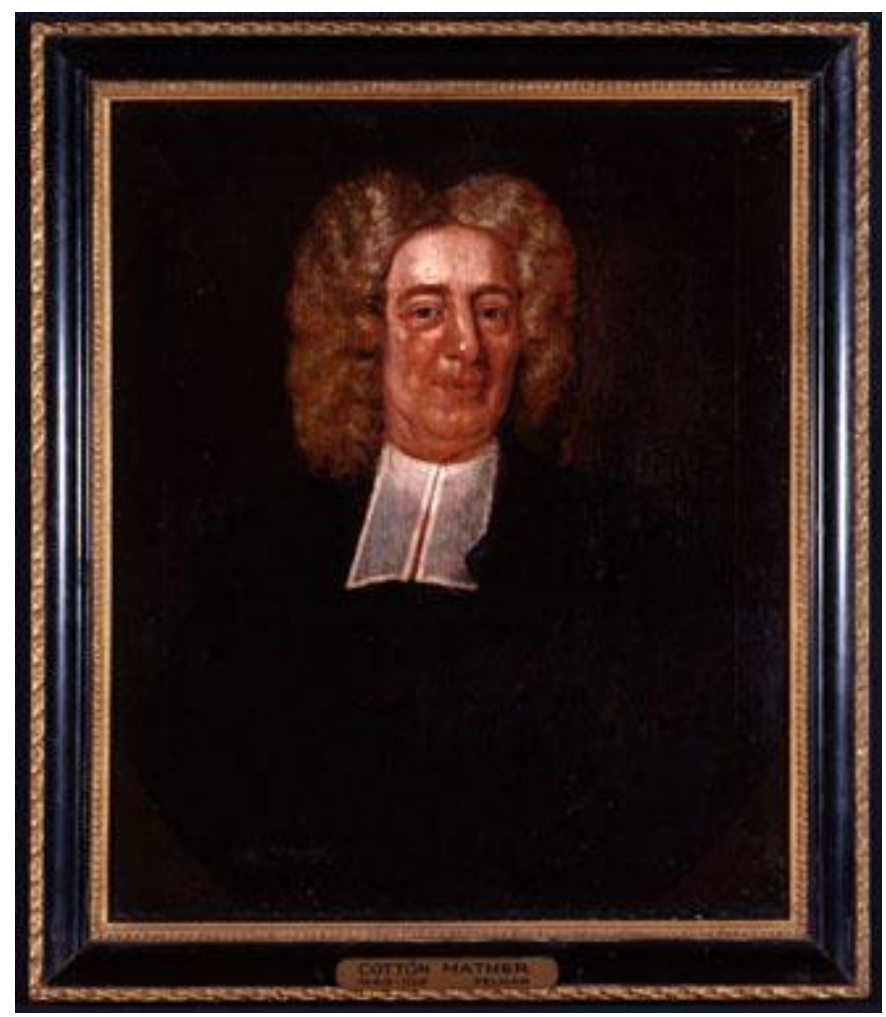

Figure 5. Peter Pelham, Cotton Mather, 1727. Oil on canvas, 35 1/4 x $301 / 4$ in (framed), American Antiquarian Society.

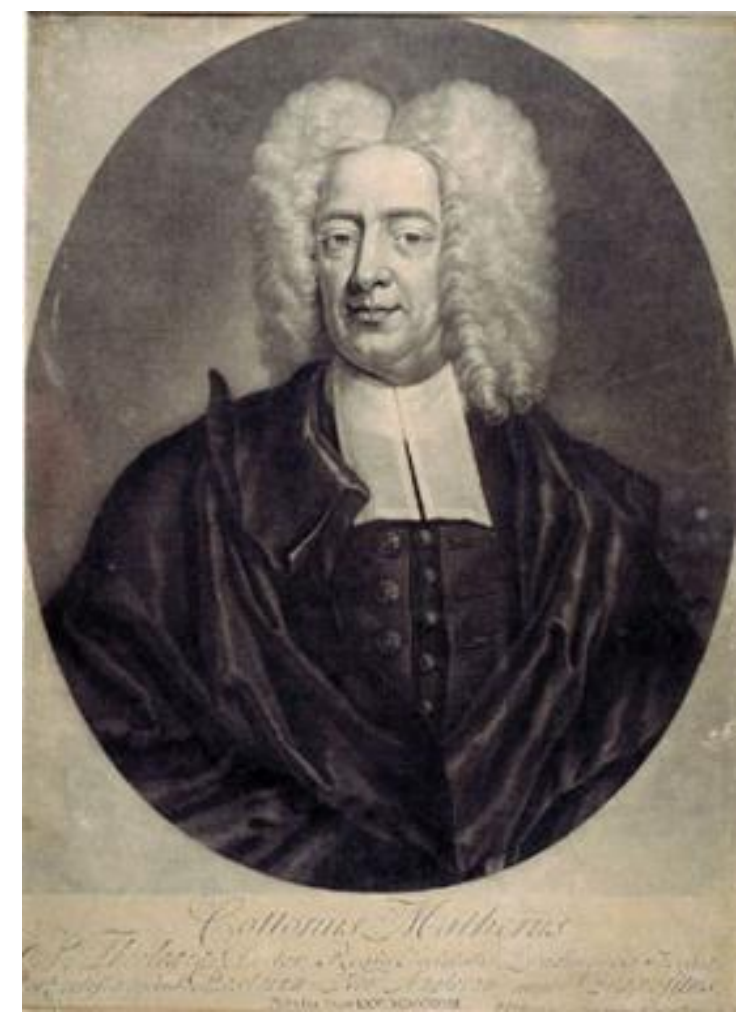

Figure 6. Peter Pelham, Cottonus Matherus, 1727. Mezzotint, American Antiquarian Society. 


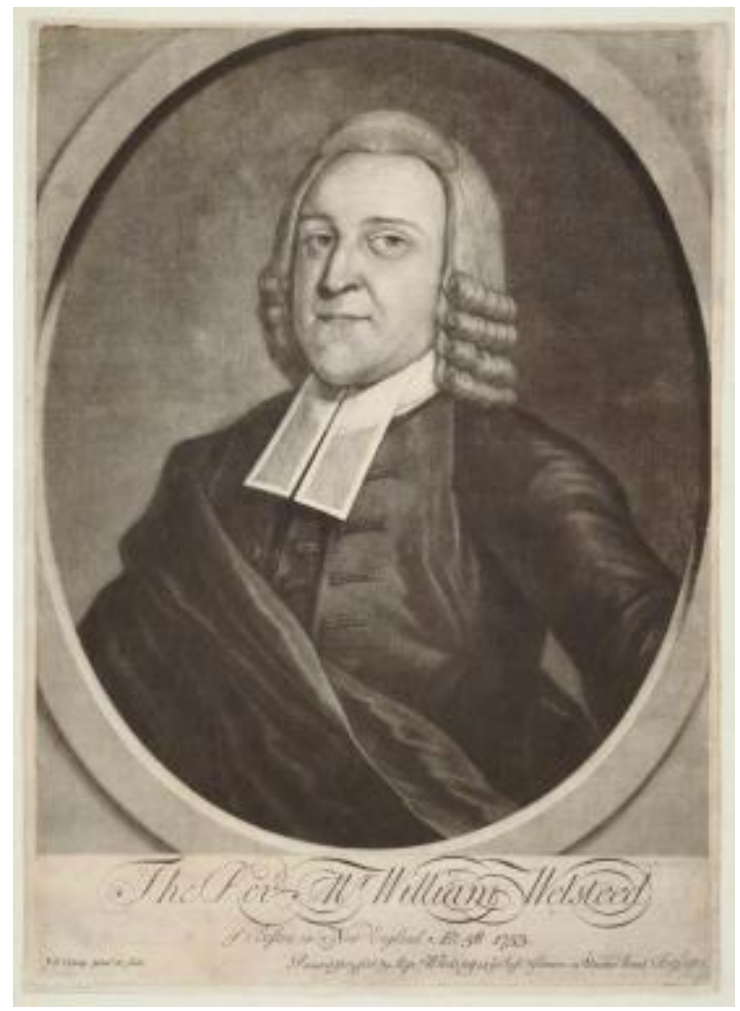

Figure 7. John Singleton Copley, Reverend William Welsteed, 1753. Mezzotint, 13 7/8 x 9 13/16 in. (platemark), Museum of Fine Arts, Boston.

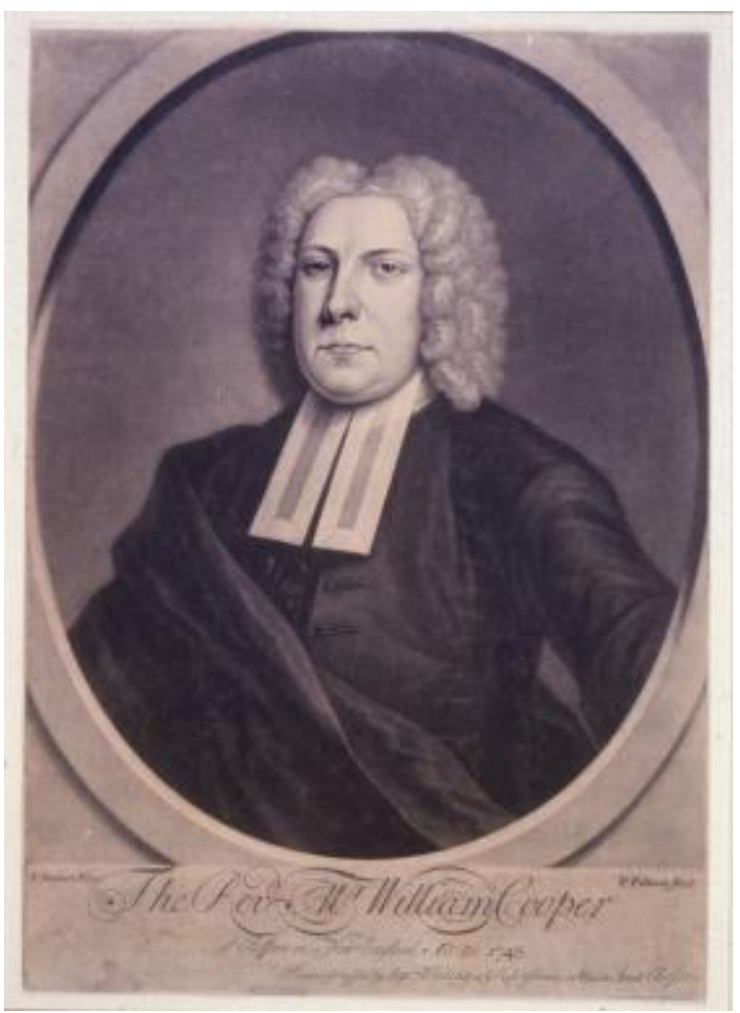

Figure 8. Peter Pelham after Jan Van der Vaart, Reverend William Cooper, 1724. Mezzotint, Museum of Fine Arts Boston. 


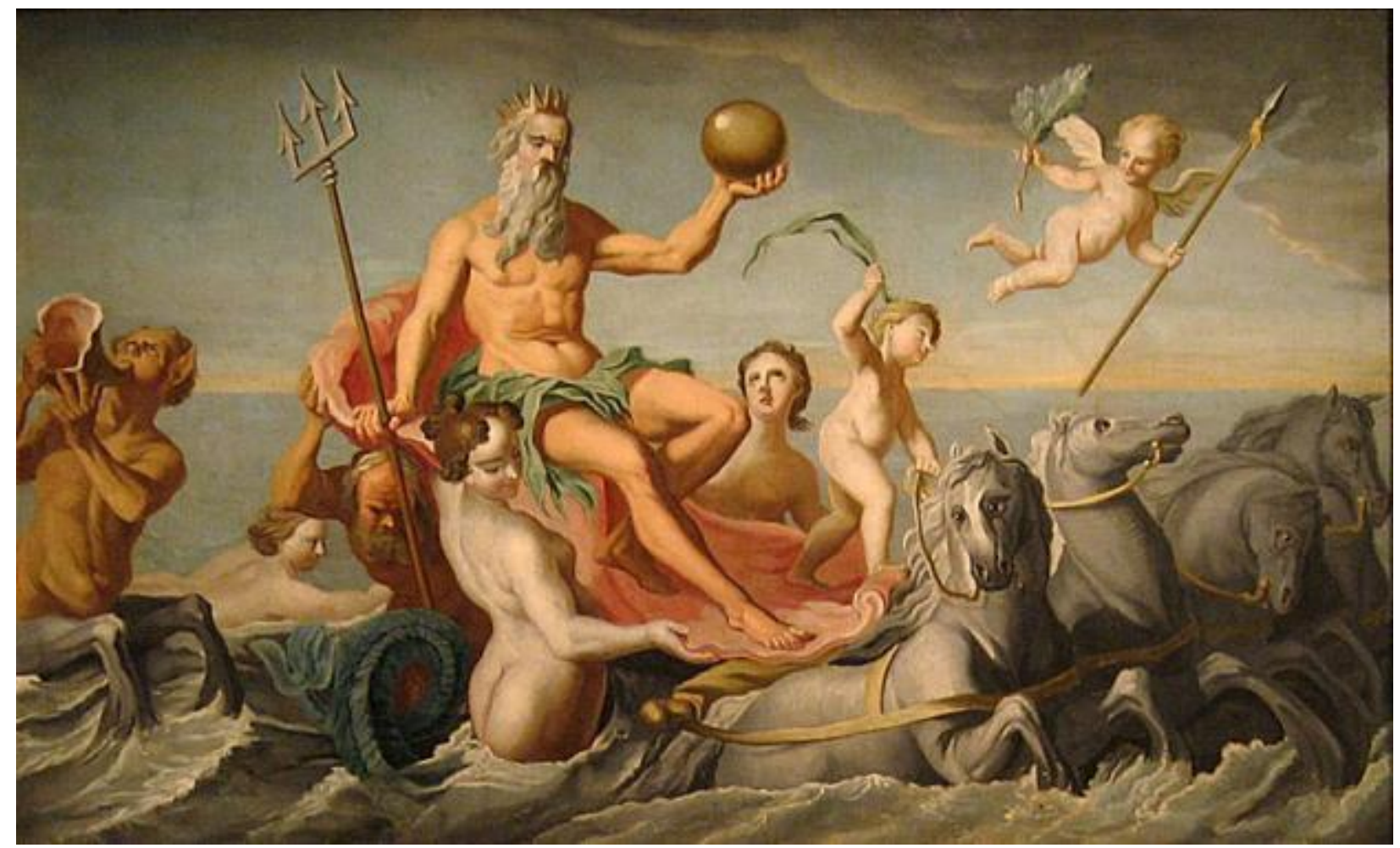

Figure 9. John Singleton Copley, The Return of Neptune, 1754. Oil on canvas, 27 1/2 x 44 1/2 in, The Metropolitan Museum of Art.

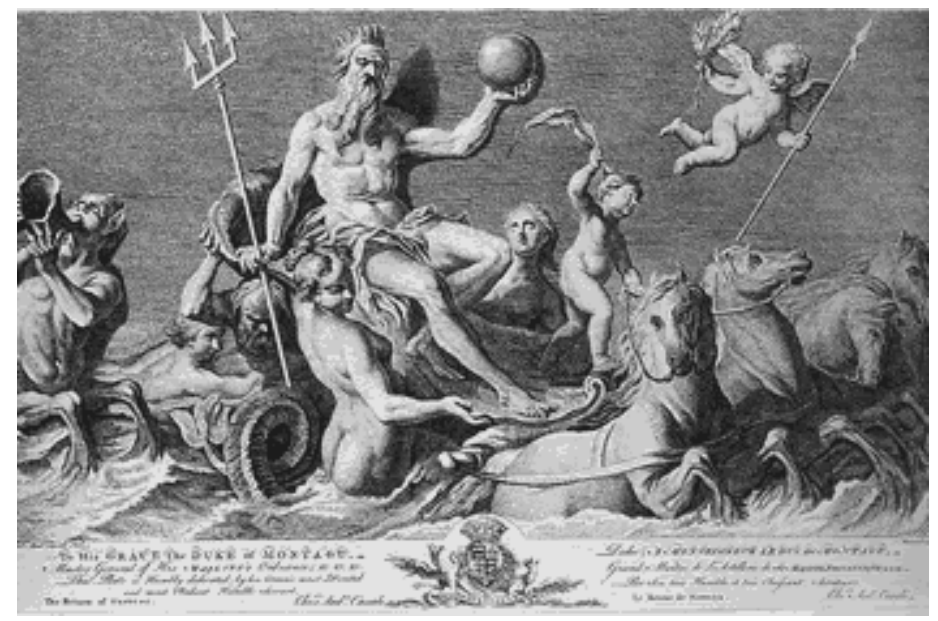

Figure 10. Simon François Ravenet after Andrea Casali, The Return of Neptune, 1749. Mezzotint, The Metropolitan Museum of Art. 


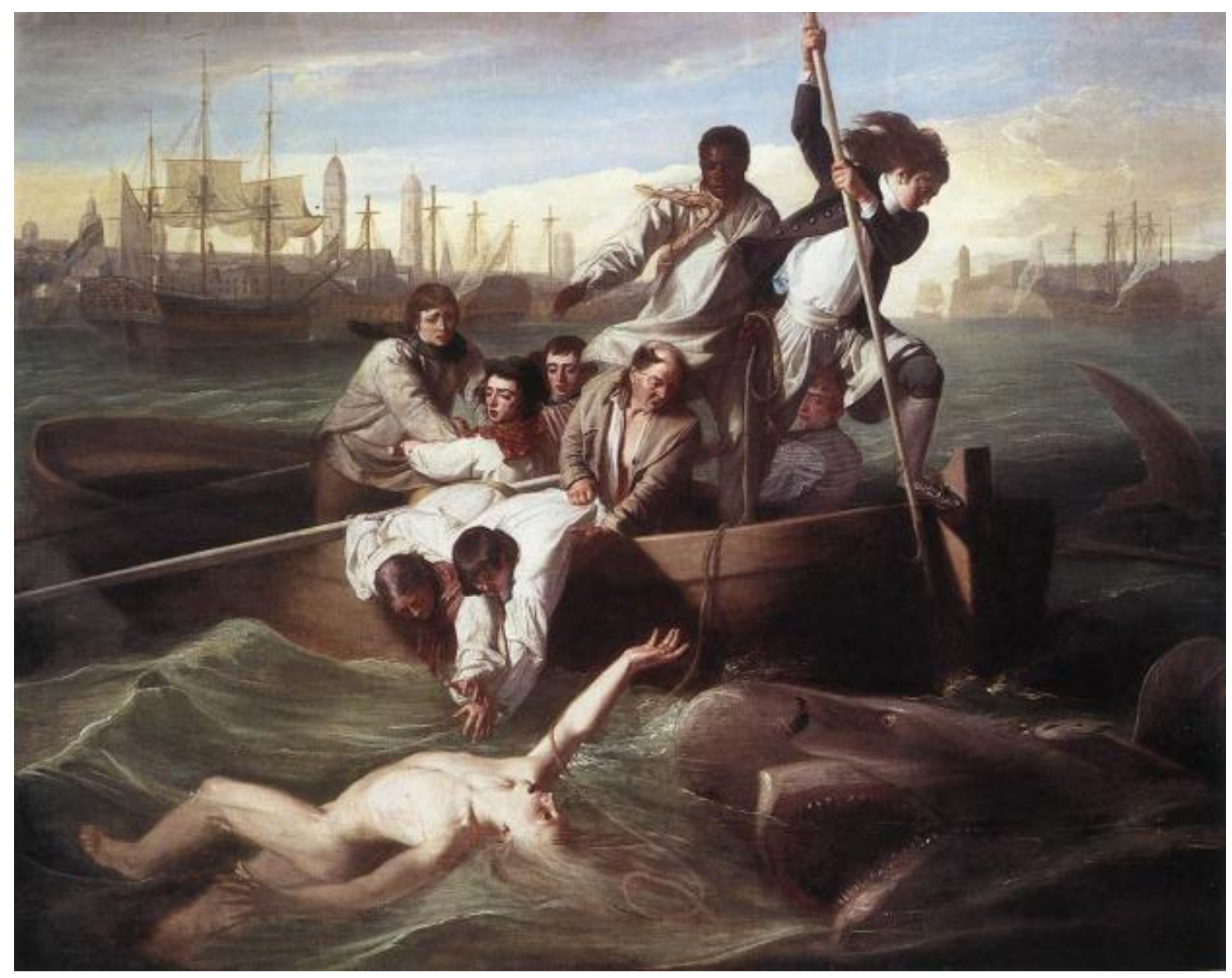

Figure 11. John Singleton Copley, Watson and the Shark, 1778. Oil on Canvas, 72 1/4 x 90 3/8 in, Museum of Fine Arts, Boston. 


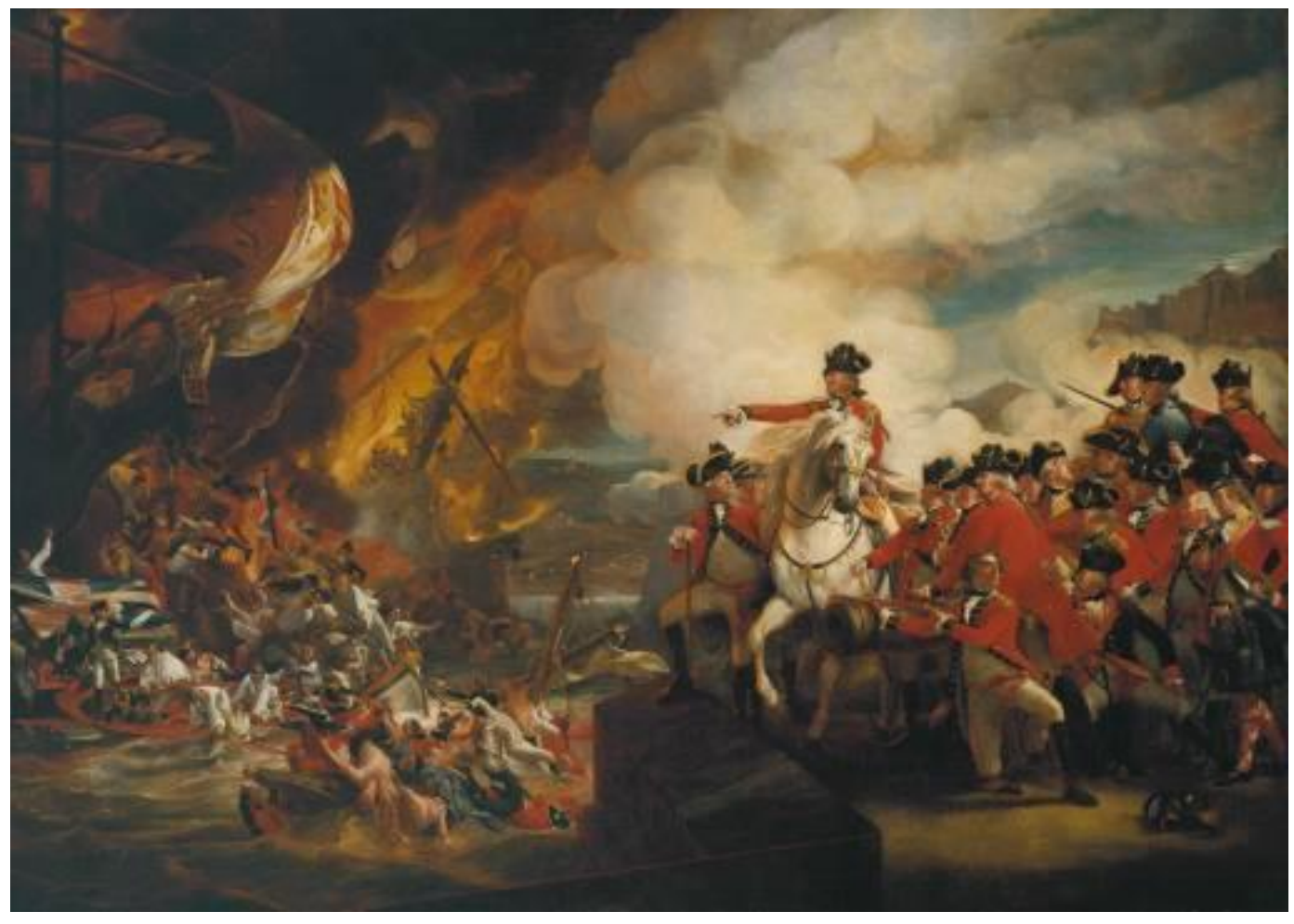

Figure 12. John Singleton Copley, Defeat of the Floating Batteries at Gibraltar (The Siege and Relief of Gibraltar), 1782. Oil on Canvas, 214 x 297 in, Guildhall Art Gallery, London. 


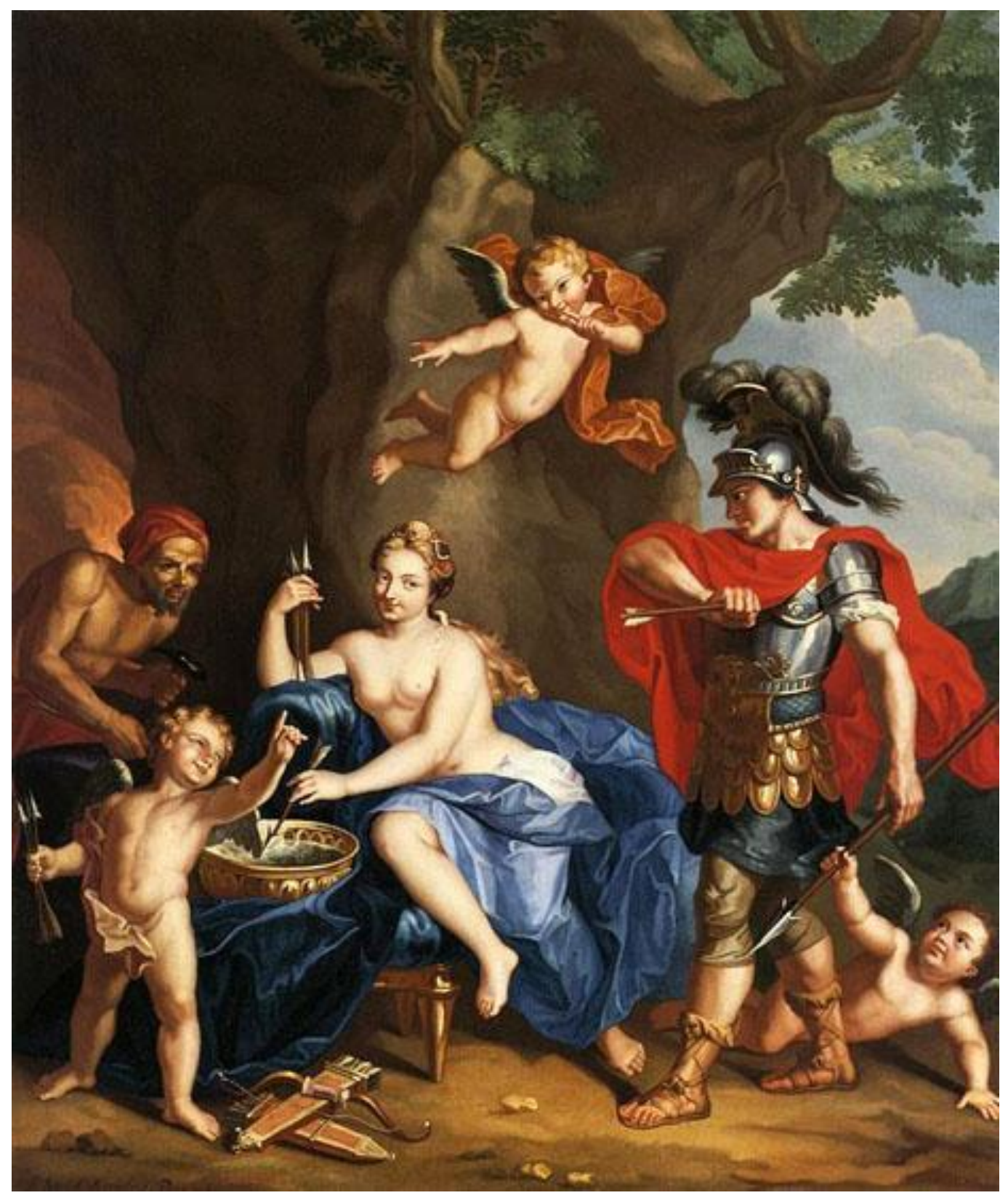

Figure 13. John Singleton Copley, Mars, Venus, and Vulcan, 1754. Oil on Canvas, 30 x 25 in, Private collection. 


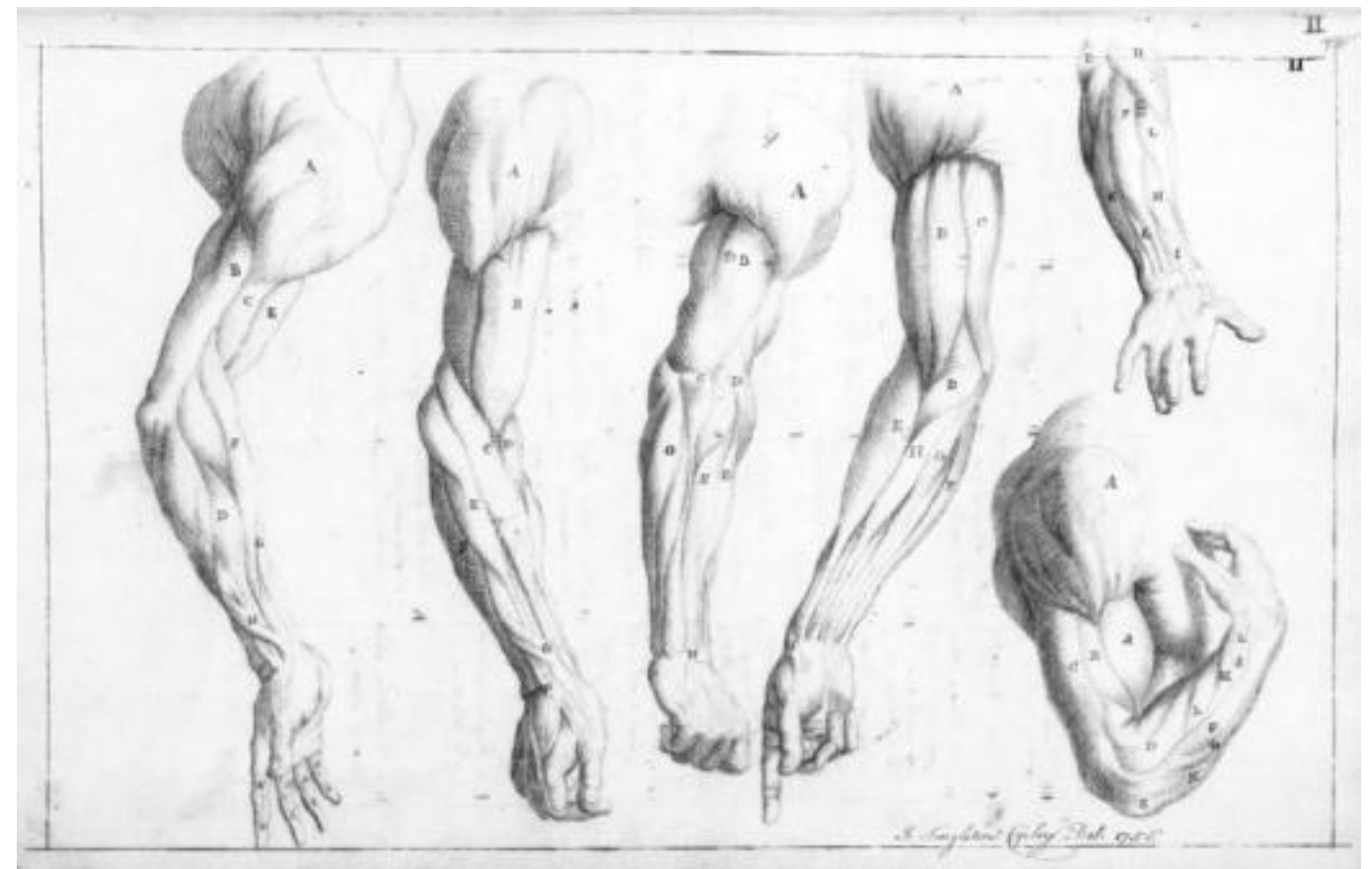

Figure 14. John Singleton Copley, Plate II, Book of Anatomical Drawings, 1756. The British Museum, London.

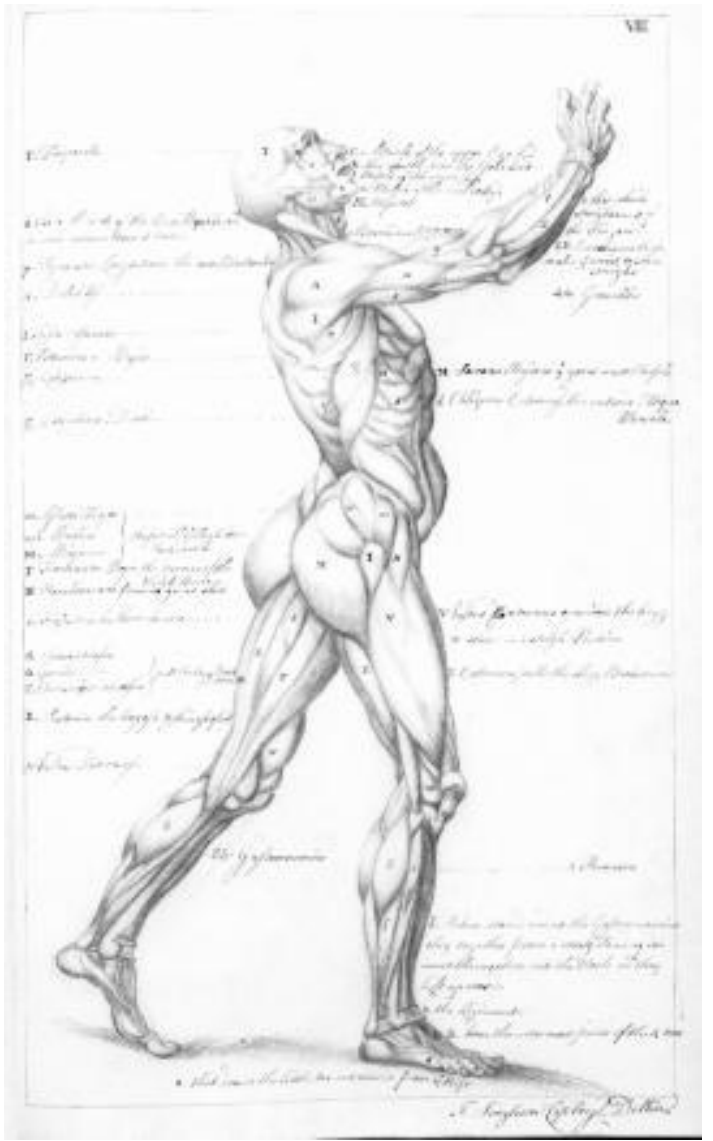

Figure 15. John Singleton Copley, Plate VIII, Book of Anatomical Drawings, 1756. The British Museum, London. 


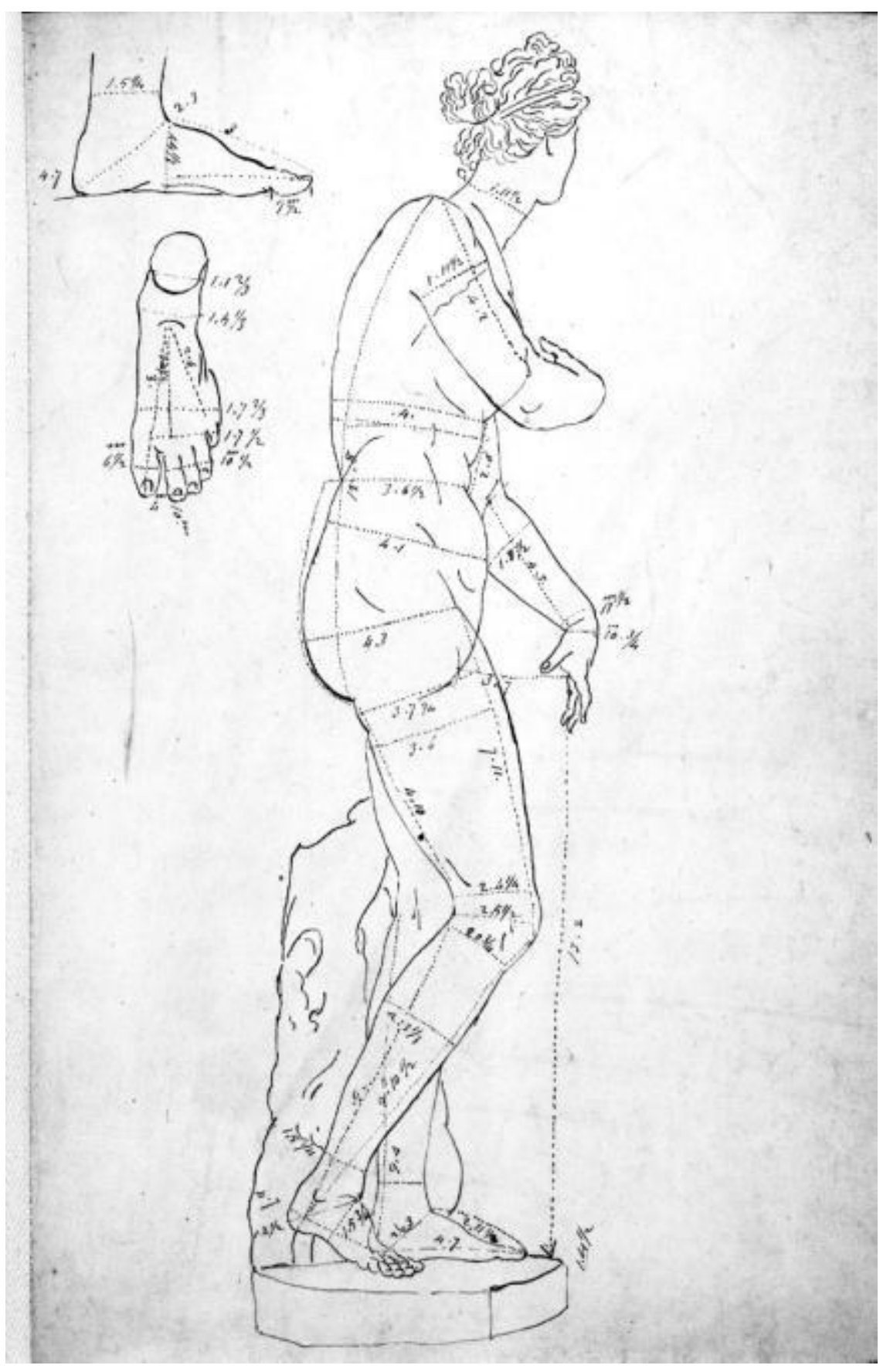

Figure 16. John Singleton Copley, Right Measured Study of the Venus Medici, 1756. The British Museum, London. 


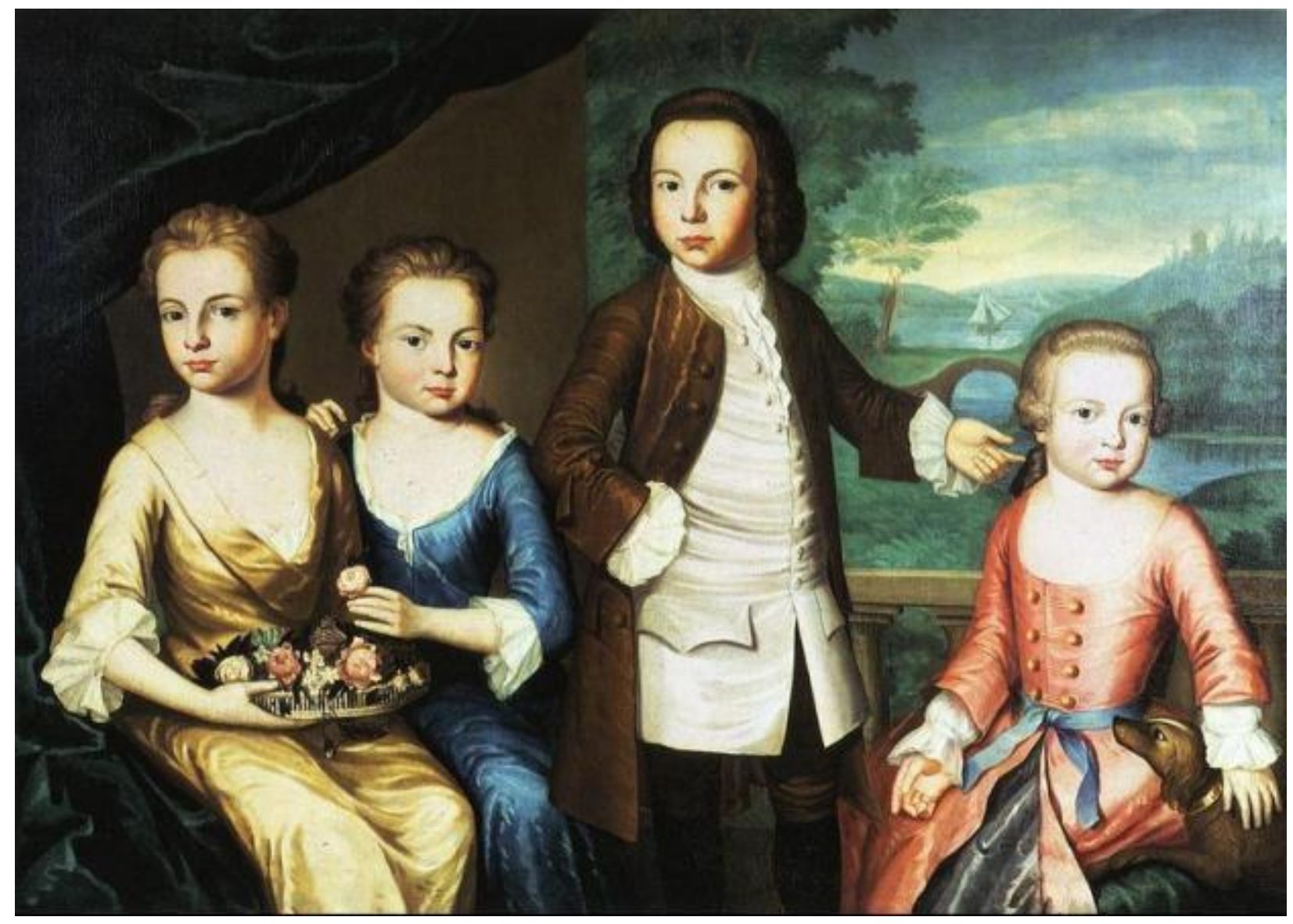

Figure 17. John Singleton Copley, The Gore Children, 1755. Oil on Canvas, 51 1/2 x 49 in, Winterthur. 


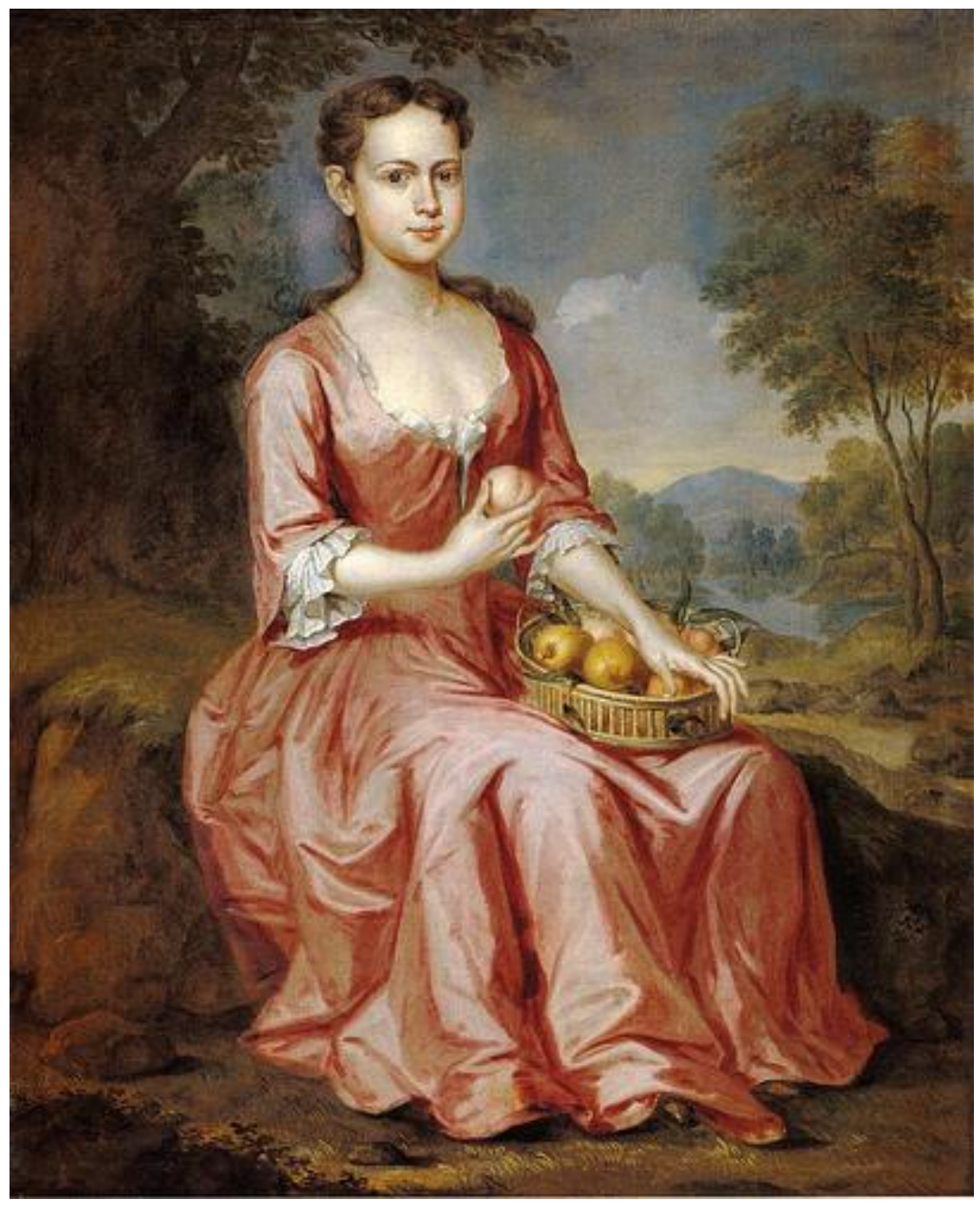

Figure 18. John Smibert, Jane Clark, 1732. Oil on Canvas, 49 x 39 1⁄2 in., Massachusetts Historical Society. 


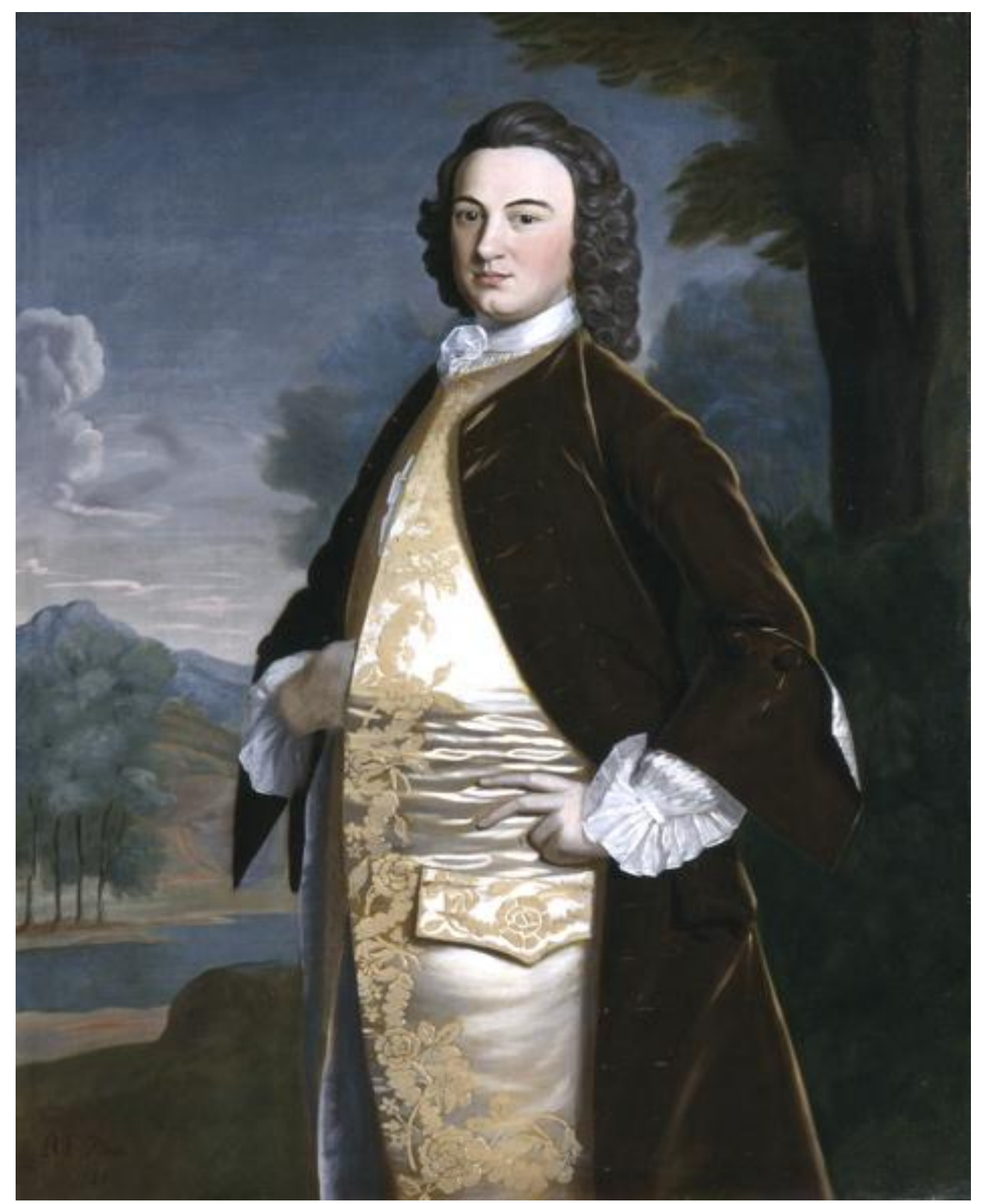

Figure 19. Robert Feke, James Bowdoin II, 1748. Oil on Canvas, 49 7/8 in. x 40 5/16 in., Bowdoin College Museum of Art. 


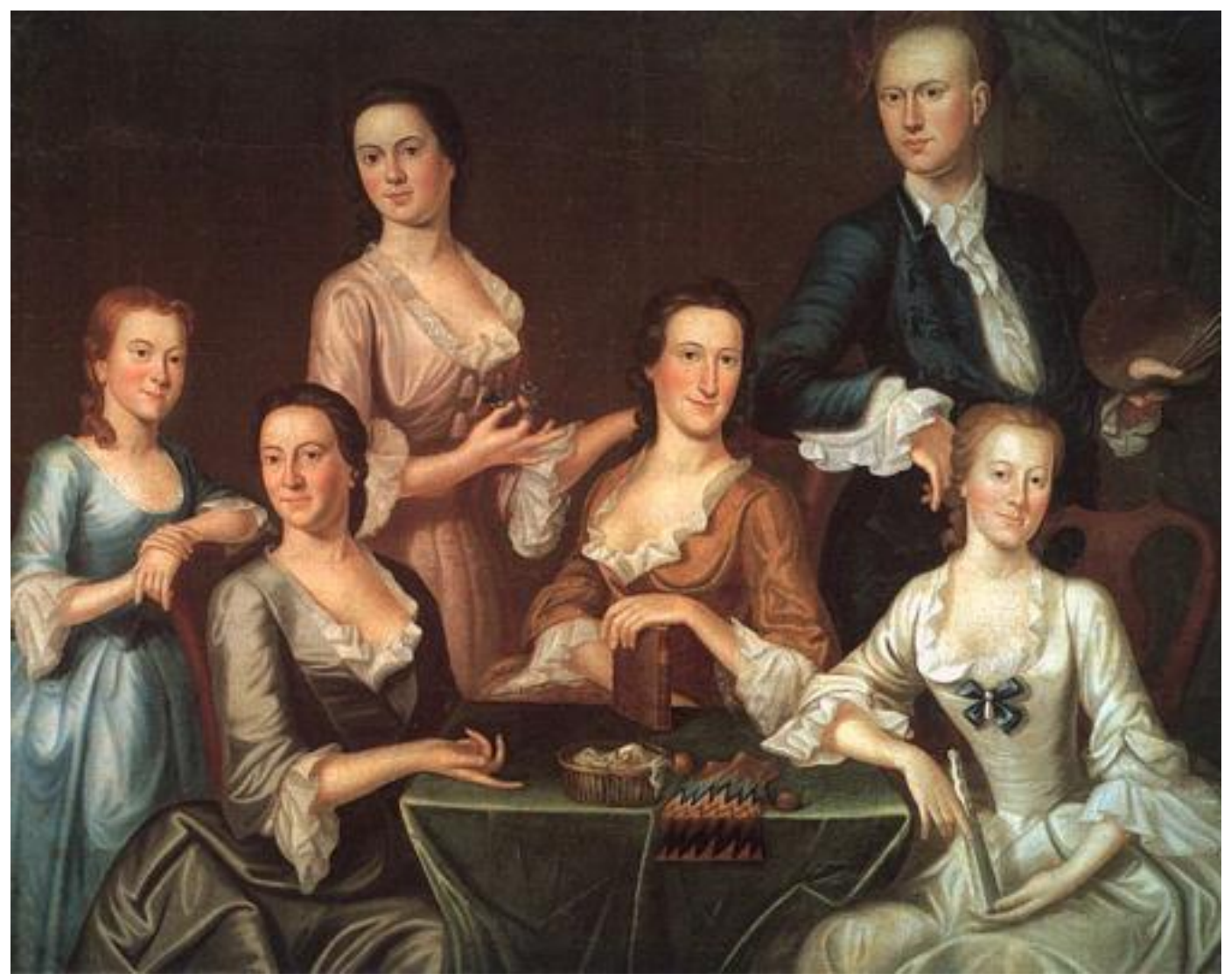

Figure 20. John Greenwood, Greenwood-Lee Family, 1747. Oil on canvas, 55 1/2 x 69 1/8 in., Museum of Fine Arts, Boston. 


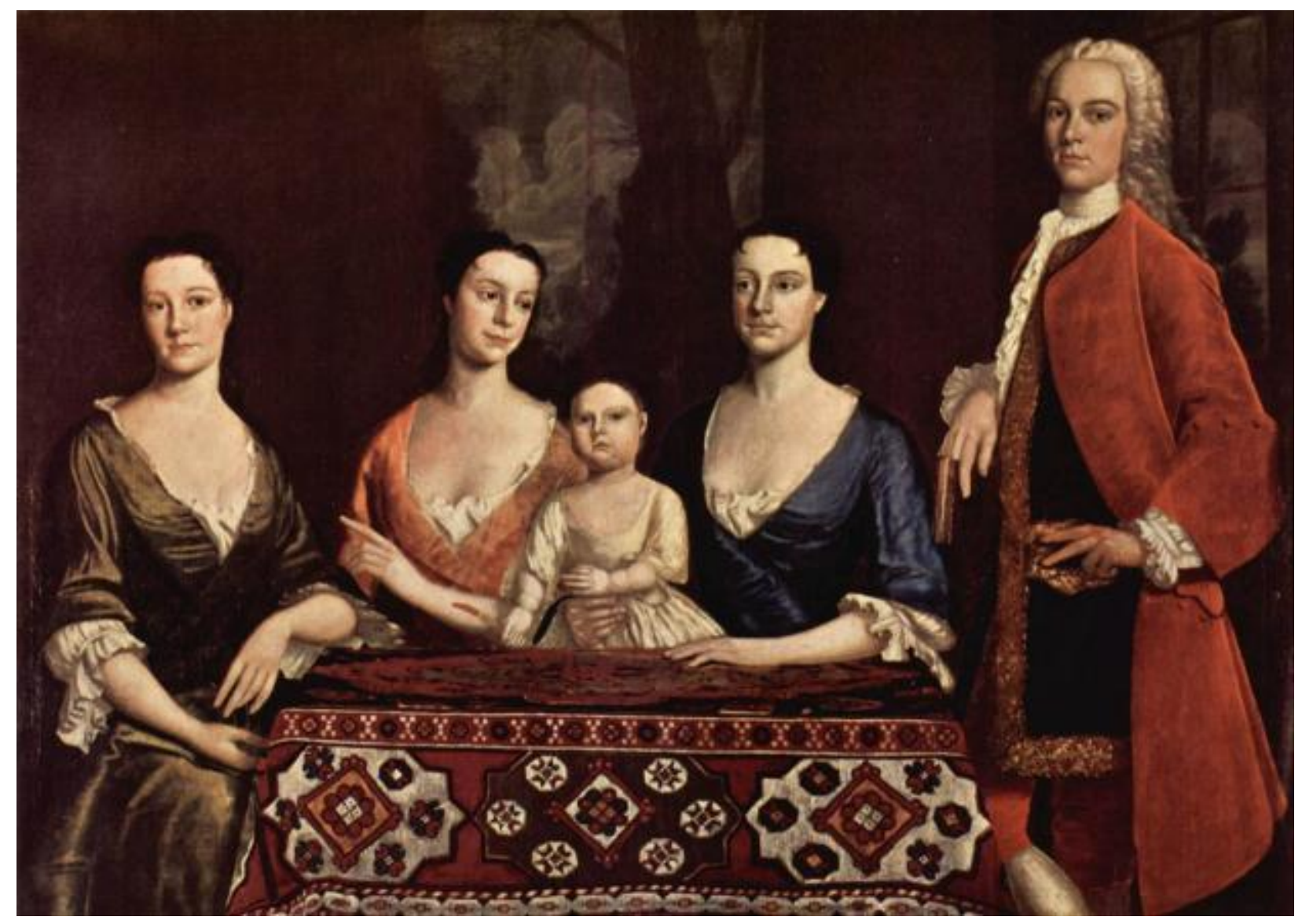

Figure 21. Robert Feke, The Isaac Royall Family, 1741. Oil on Canvas, Size not given, Harvard Law School, Caspersen Room. 


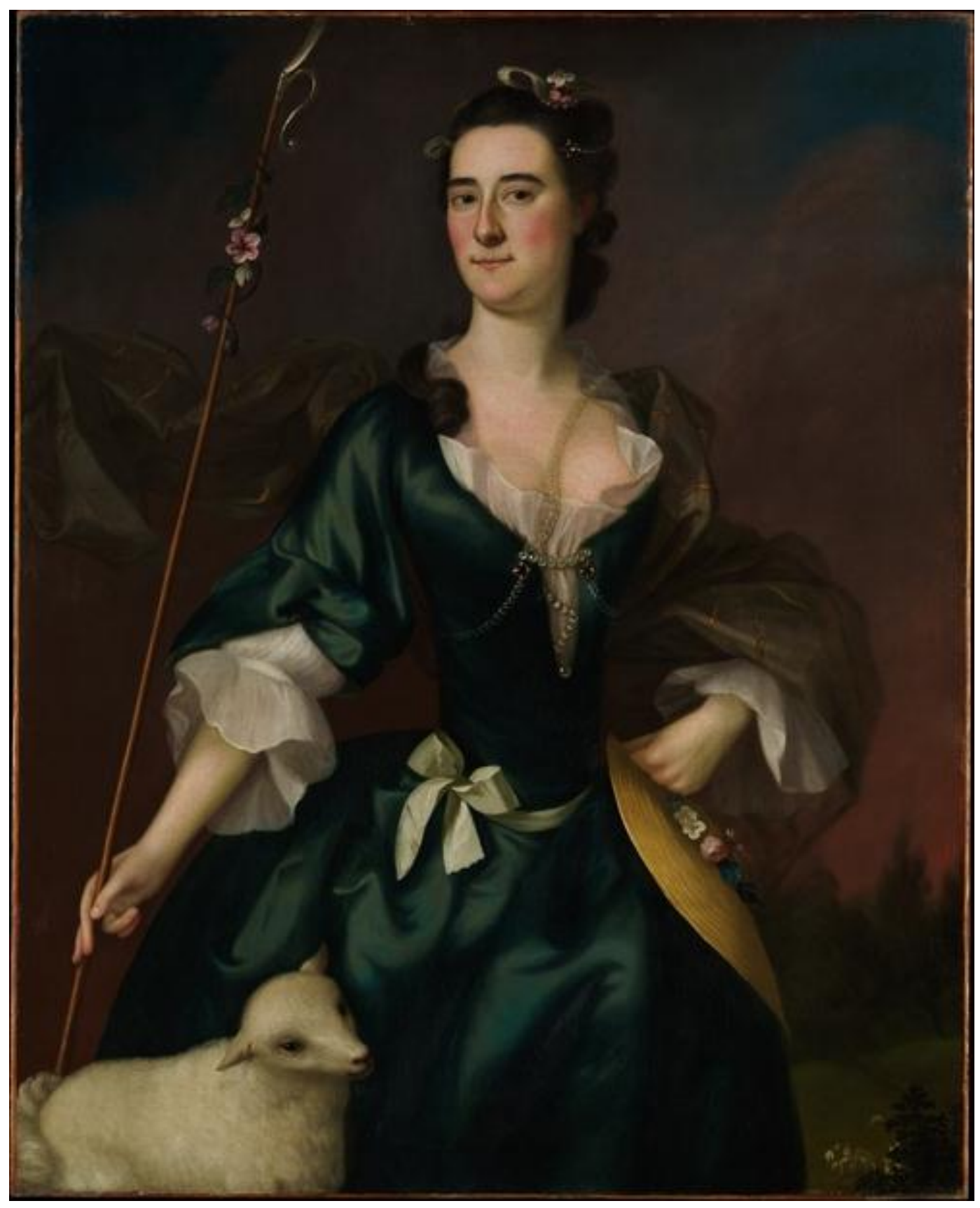

Figure 22. Joseph Blackburn, Mary Sylvester, 1754. Oil on Canvas, 49 7/8 x 40 in., The Metropolitan Museum of Art. 


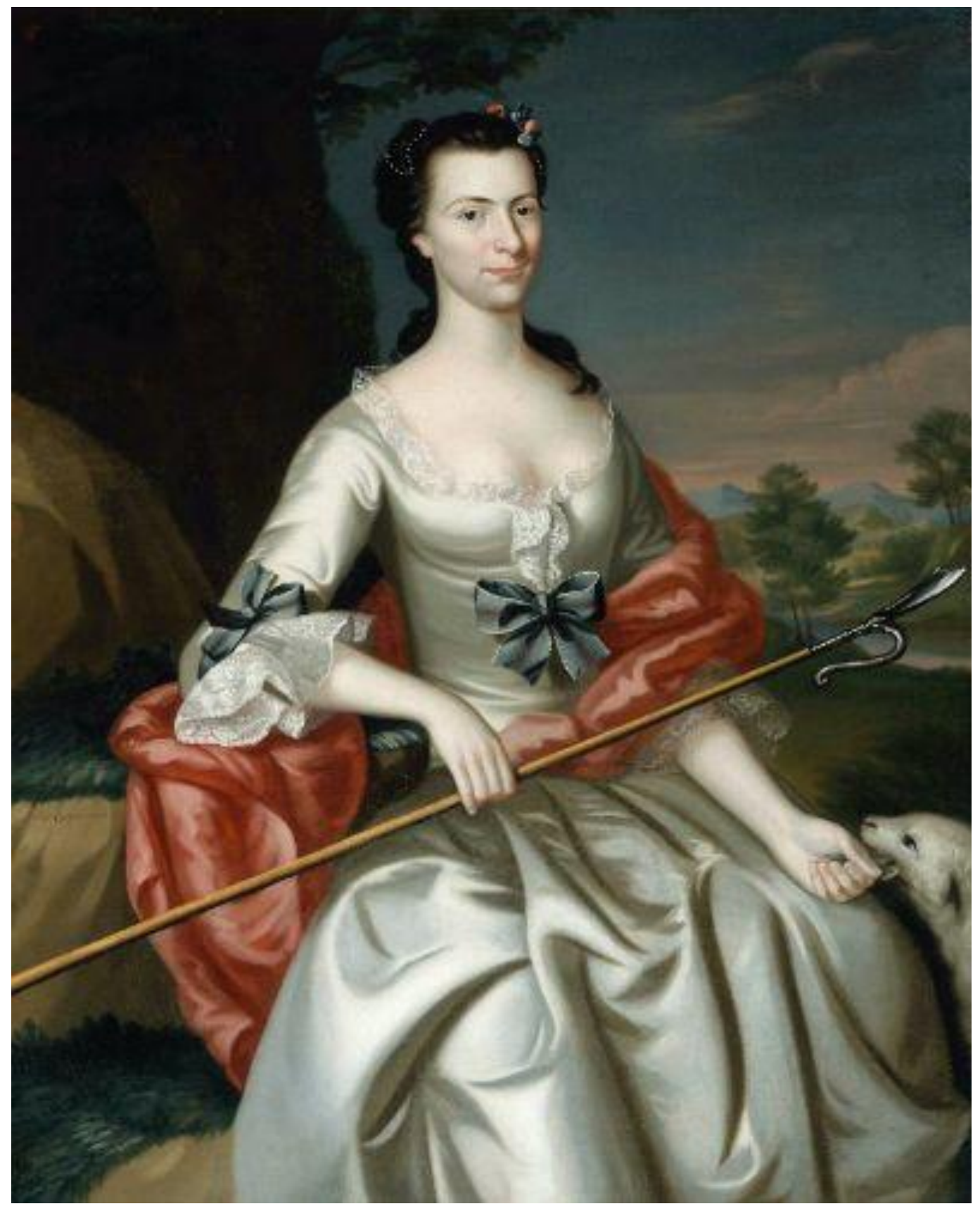

Figure 23. John Singleton Copley, Ann Tyng Smelt (Mrs. Thomas Smelt), 1756. Oil on Canvas, $501 / 8$ x 40 3/8 in., Museum of Fine Arts, Boston. 


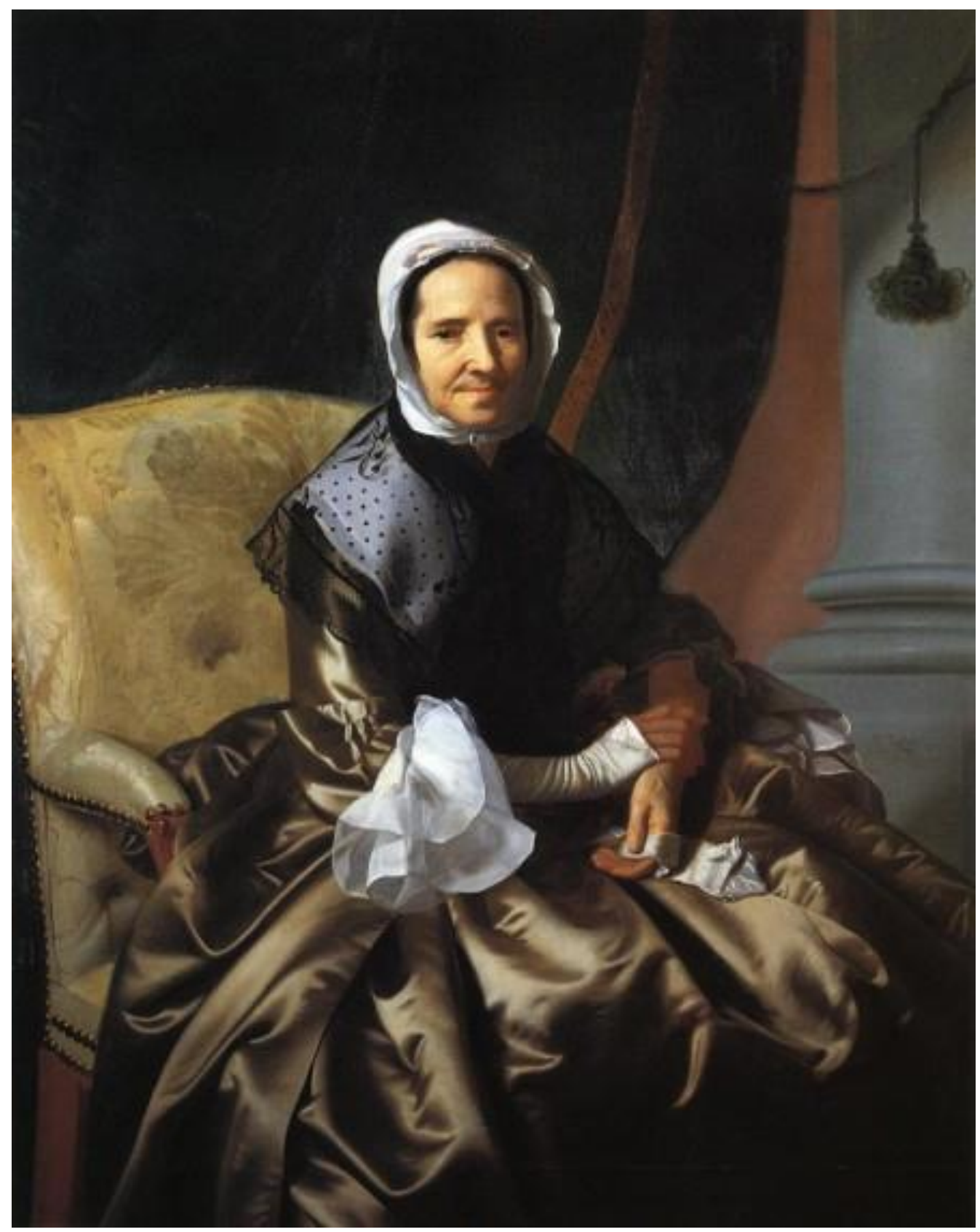

Figure 24. John Singleton Copley, Sarah Boylston (Mrs. Thomas Boylston), 1765-66. Oil on Canvas, 40.16 x 51.18 in., Fogg Art Museum, Harvard University, Boston. 


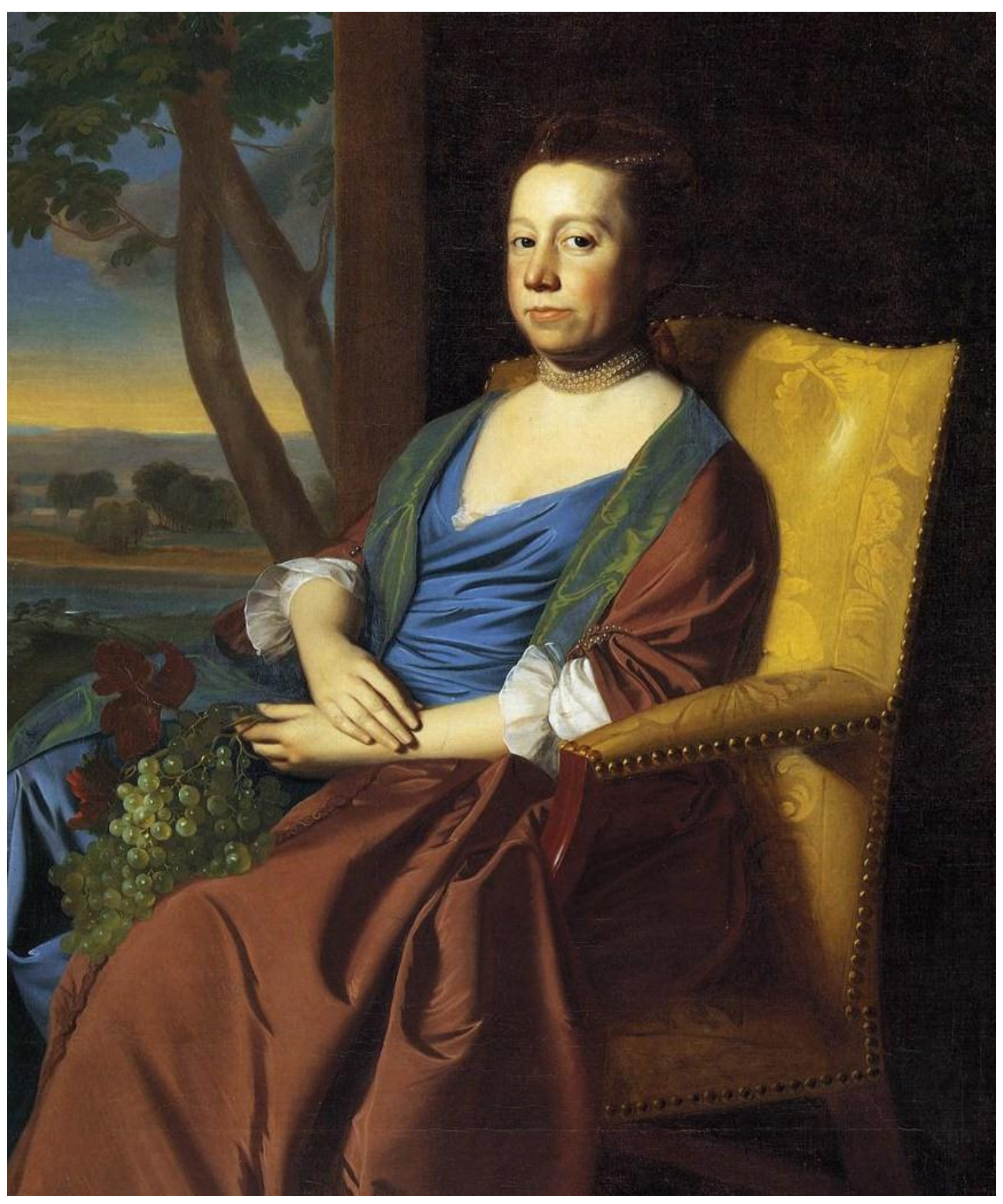

Figure 25. John Singleton Copley, Elizabeth Smith (Mrs. Isaac Smith), 1769. Oil on Canvas, 50 1/8 x 40 1/8 in., Yale University Art Gallery. 


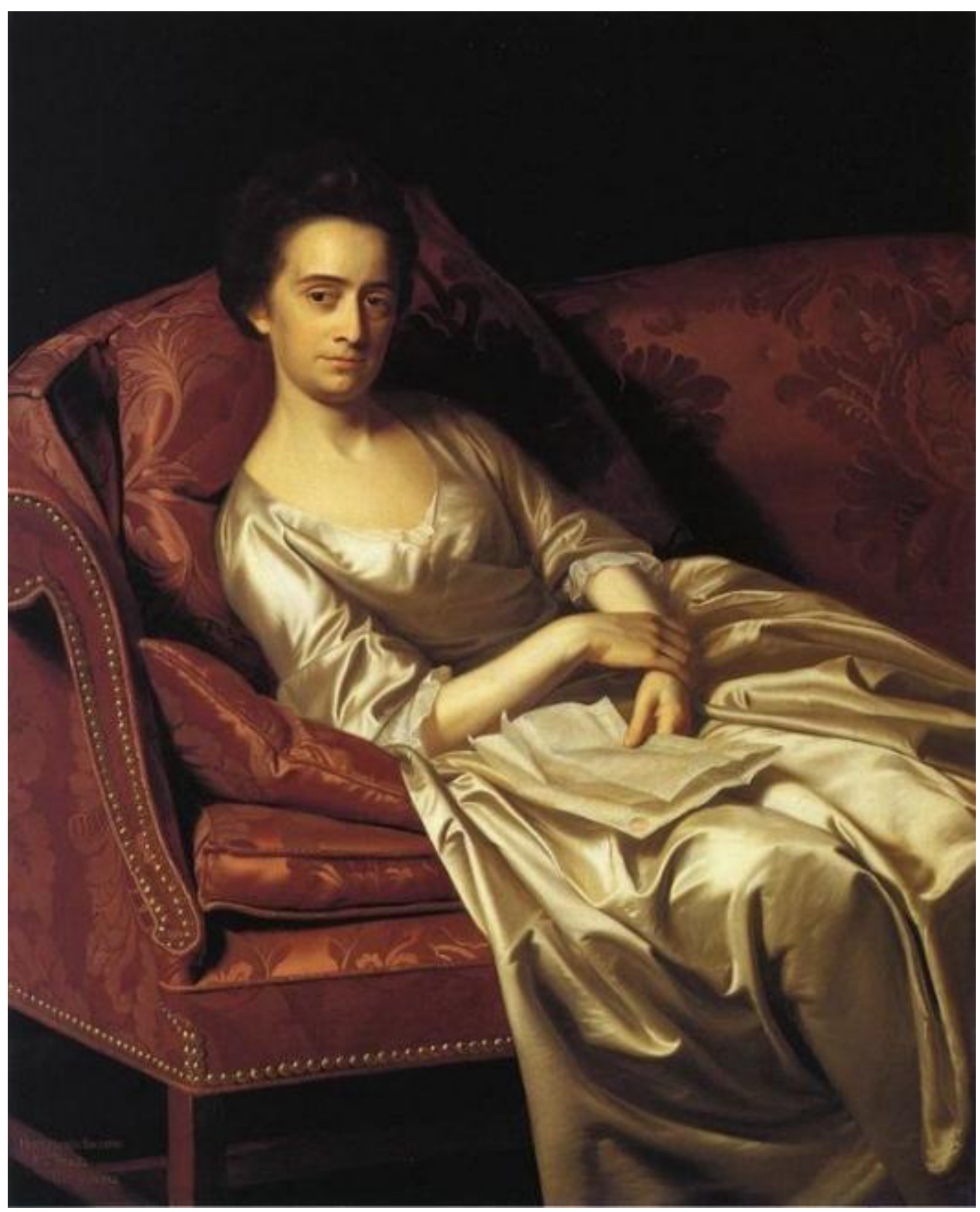

Figure 26. John Singleton Copley, Portrait of a Lady, 1771. Oil on Canvas, 49 15/16 x 39 1/2 in., Los Angeles County Museum of Art. 


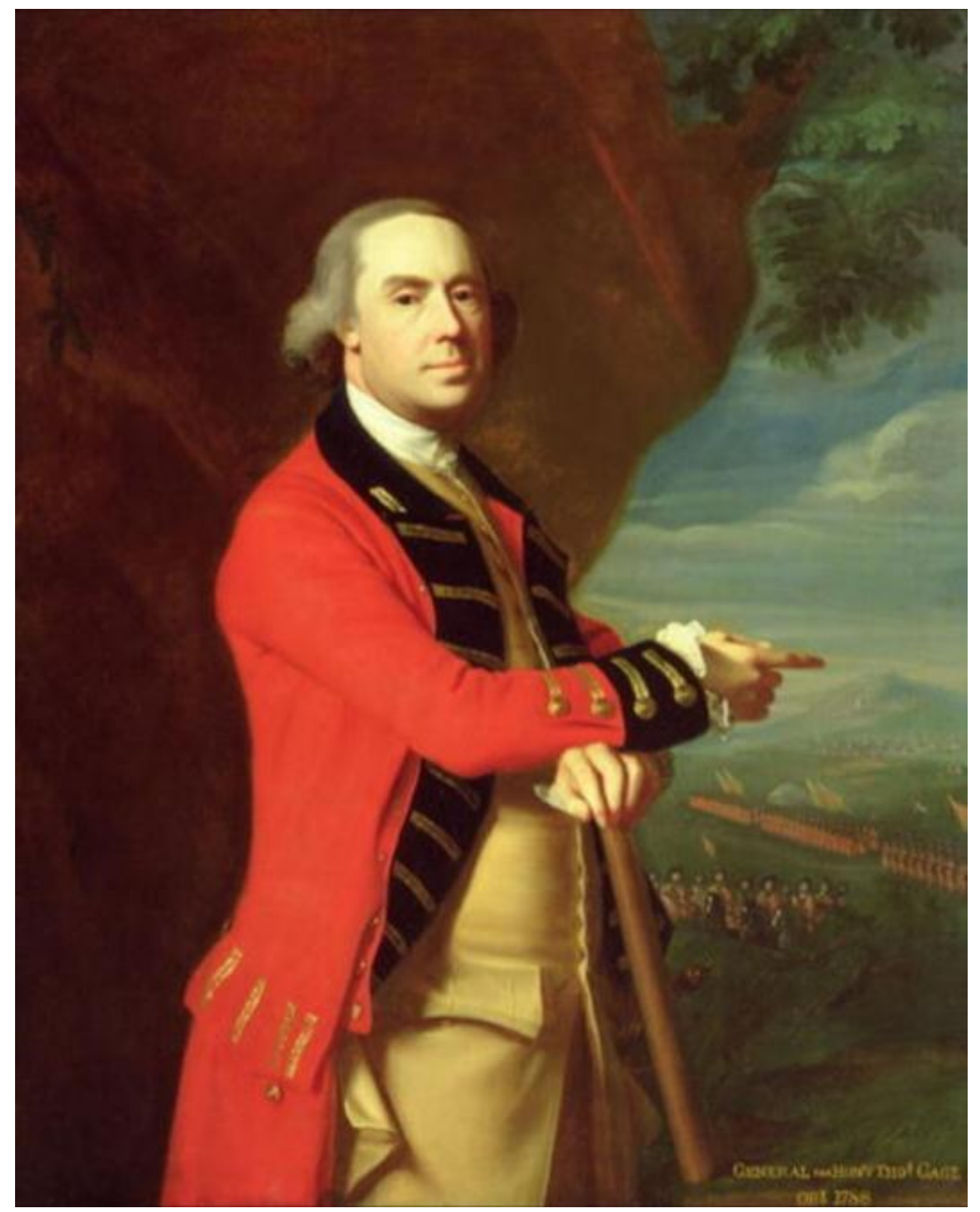

Figure 27. John Singleton Copley, General Thomas Gage, 1768. Oil on Canvas, 39 3/4 i. x 50 in., Yale Centre for British Art. 


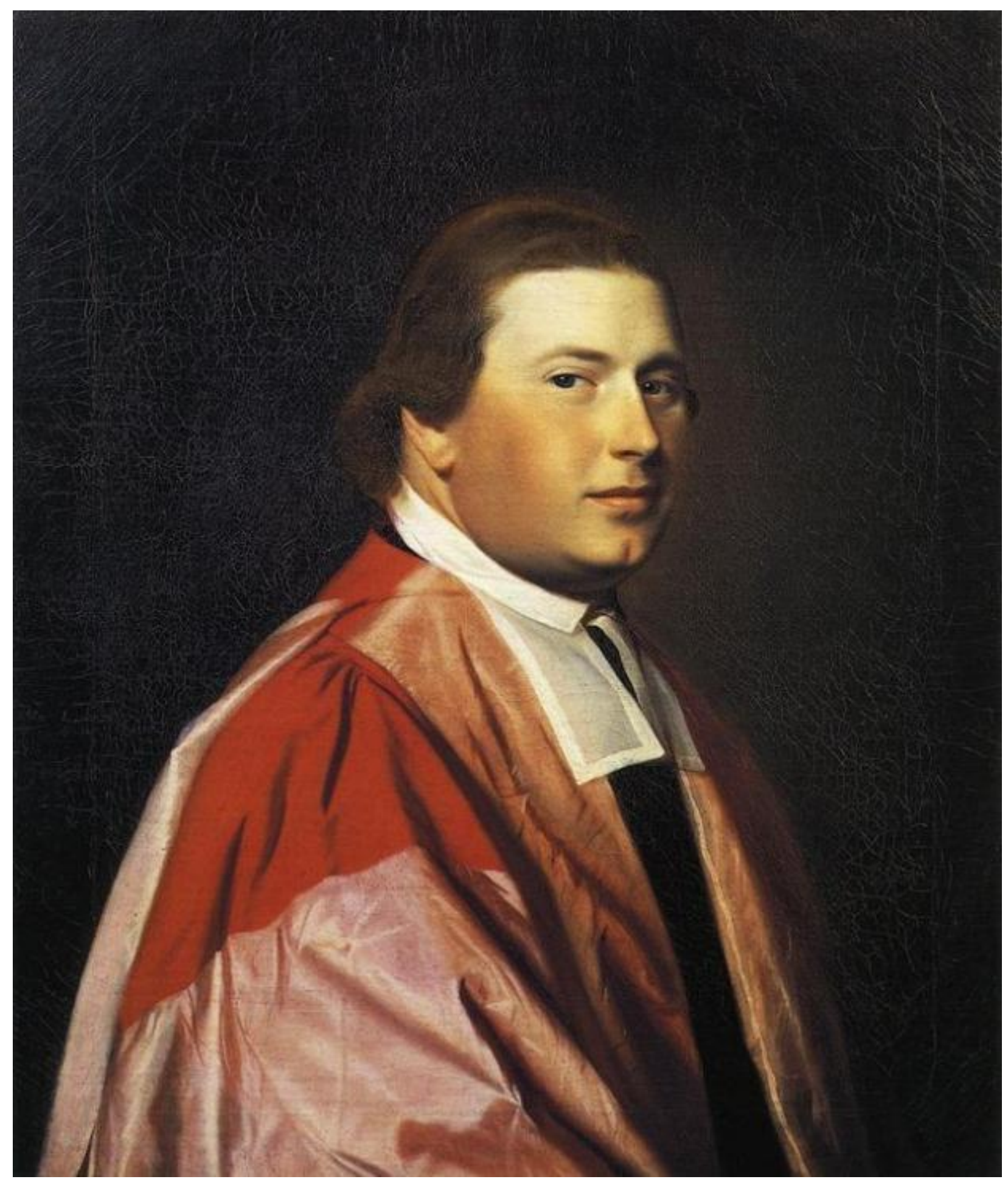

Figure 28. John Singleton Copley, Reverend Myles Cooper, 1768-1769. Oil on Canvas, 30 x 25 in., Columbia University, New York. 


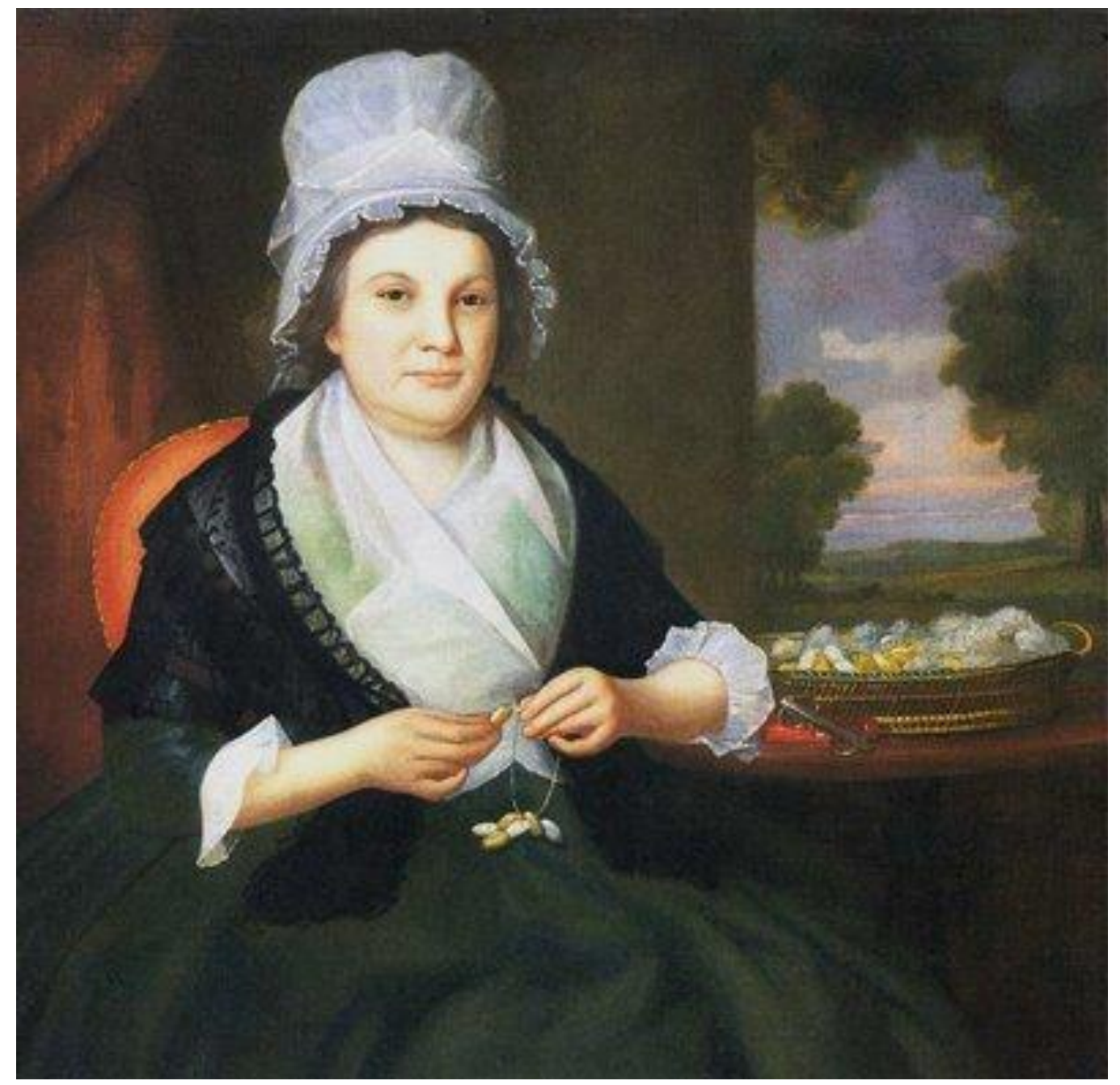

Figure 29. Ralph Earl, Mrs. Charles Jeffery Smith, 1794. Oil on Canvas, 47 3/4 x 41 3/4 in., New York Historical Society. 


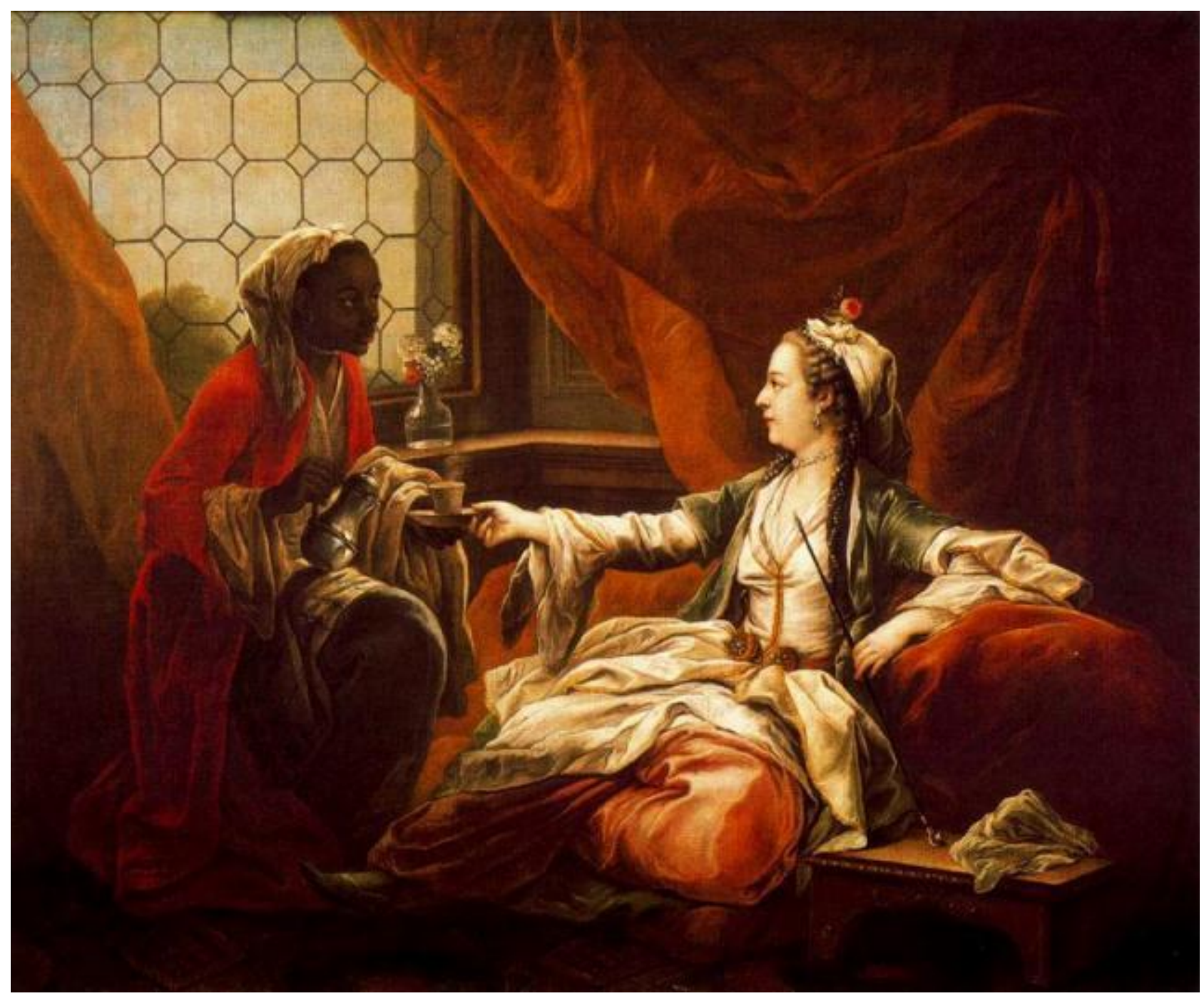

Figure 30. Carle van Loo, The Sultana Drinking Coffee, 1754. Oil on canvas, 47 1/4 x 50 in., Hermitage Museum, Saint Petersburg 


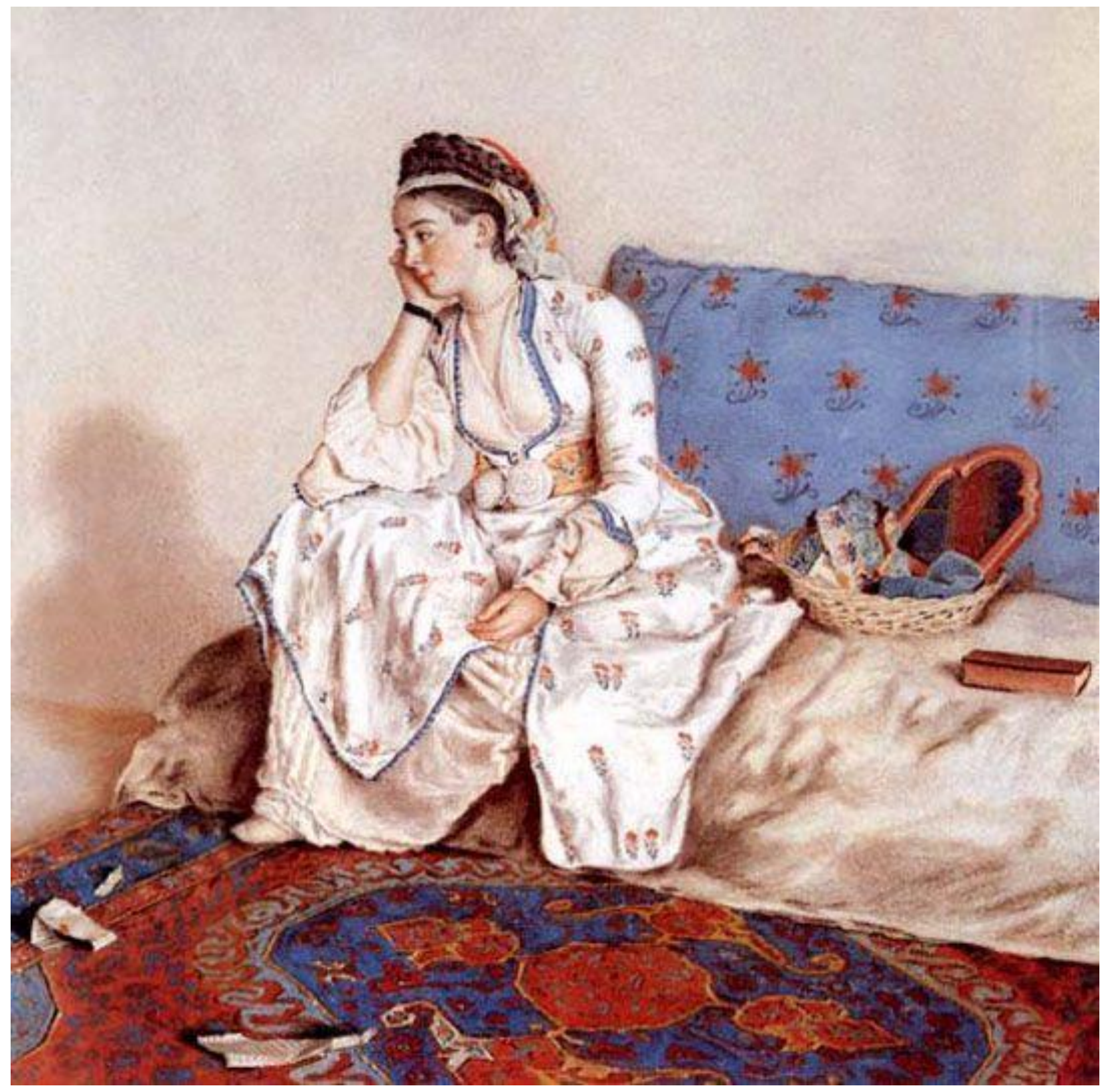

Figure 31. Jean-Étienne Liotard, Mary Gunning, Countess of Coventry, 1749. Pastel on vellum, 30 x 40 in., Rijksmuseum, Amsteradam. 


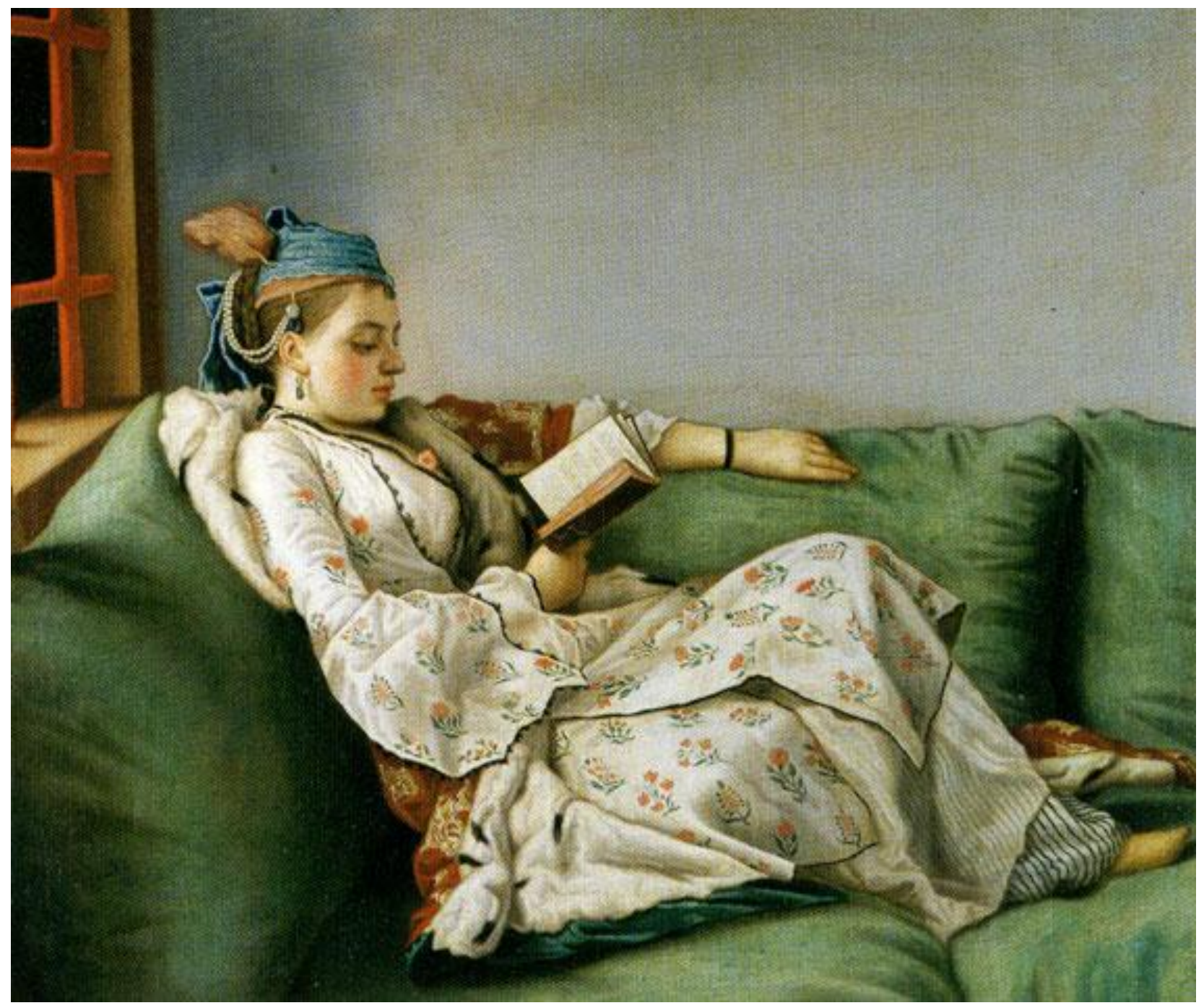

Figure 32. Jean-Étienne Liotard, Marie Adelaide of France dressed in Turkish Costume, 1753. Oil on Canvas, 50 x 56 in., Uffizi Gallery, Florence. 


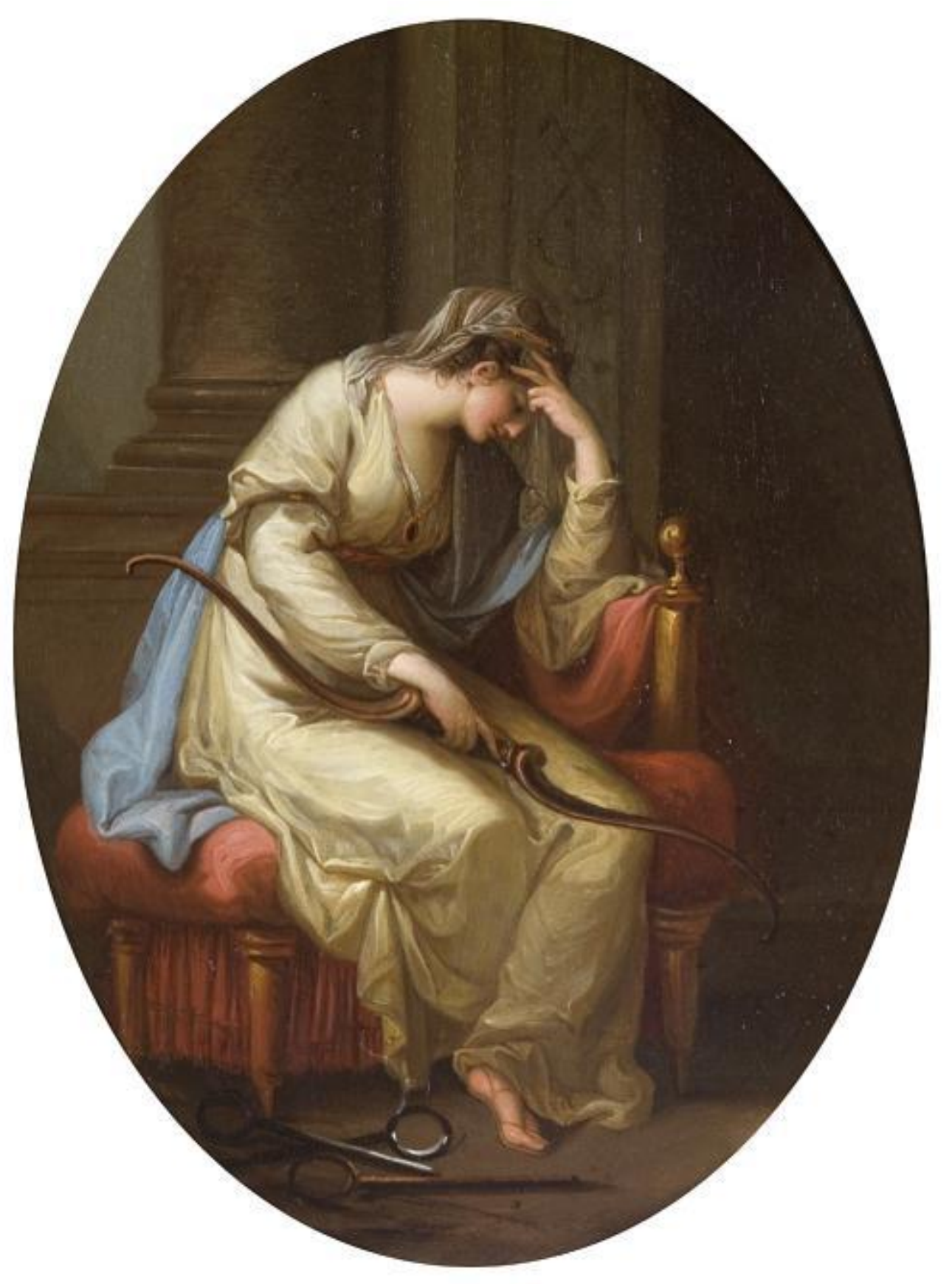

Figure 33. Angelica Kauffmann, Penelope Weeping Over the Bow of Ulysses, 1779. Oil on Copper, Wolverhampton Art Gallery, Wolverhampton. 


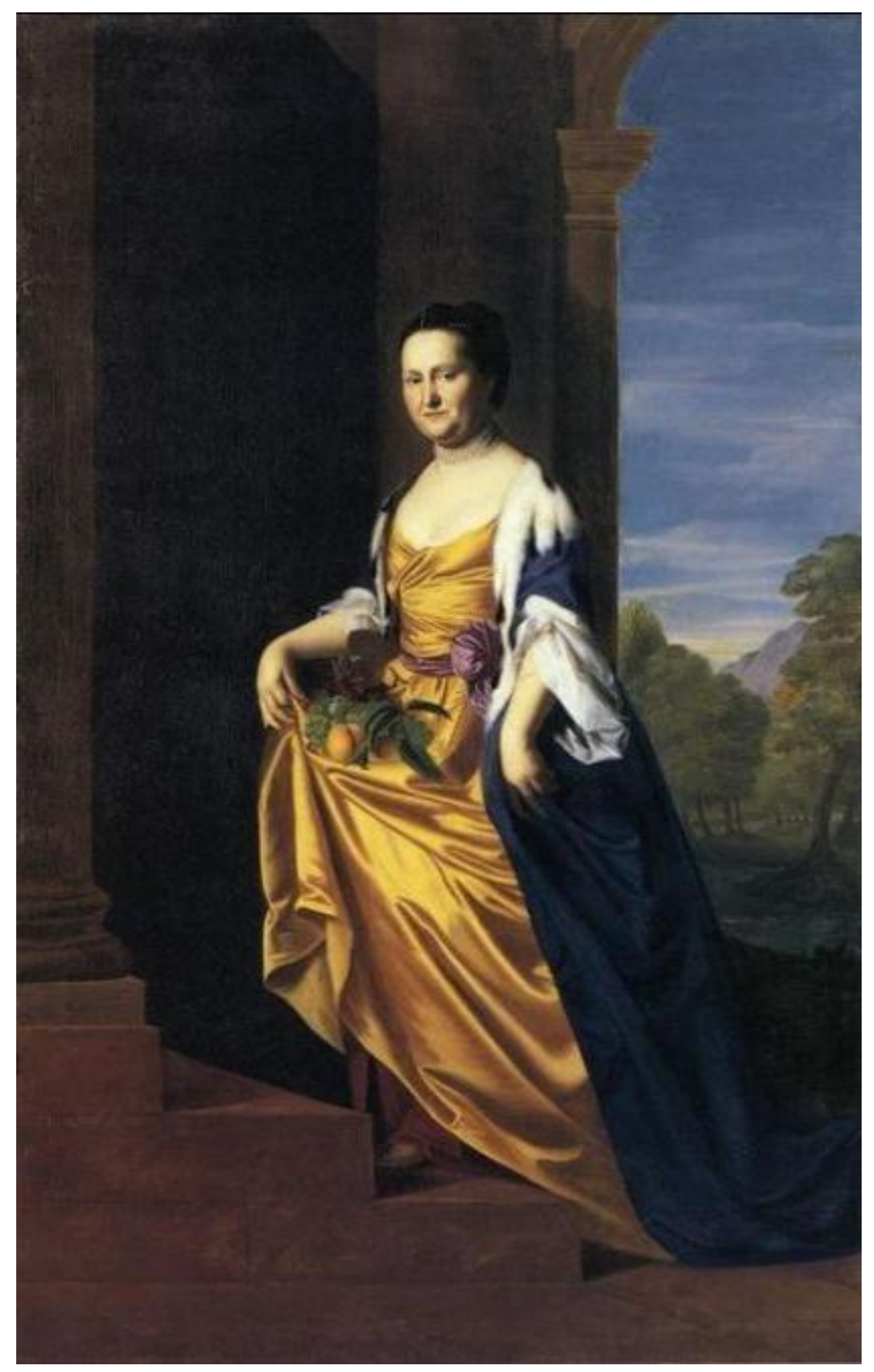

Figure 34. John Singleton Copley, Martha Swett Lee (Mrs. Jeremiah Lee), 1769. Oil on Canvas, 59 x 95 in., Wadsworth Atheneum, Connecticut. 


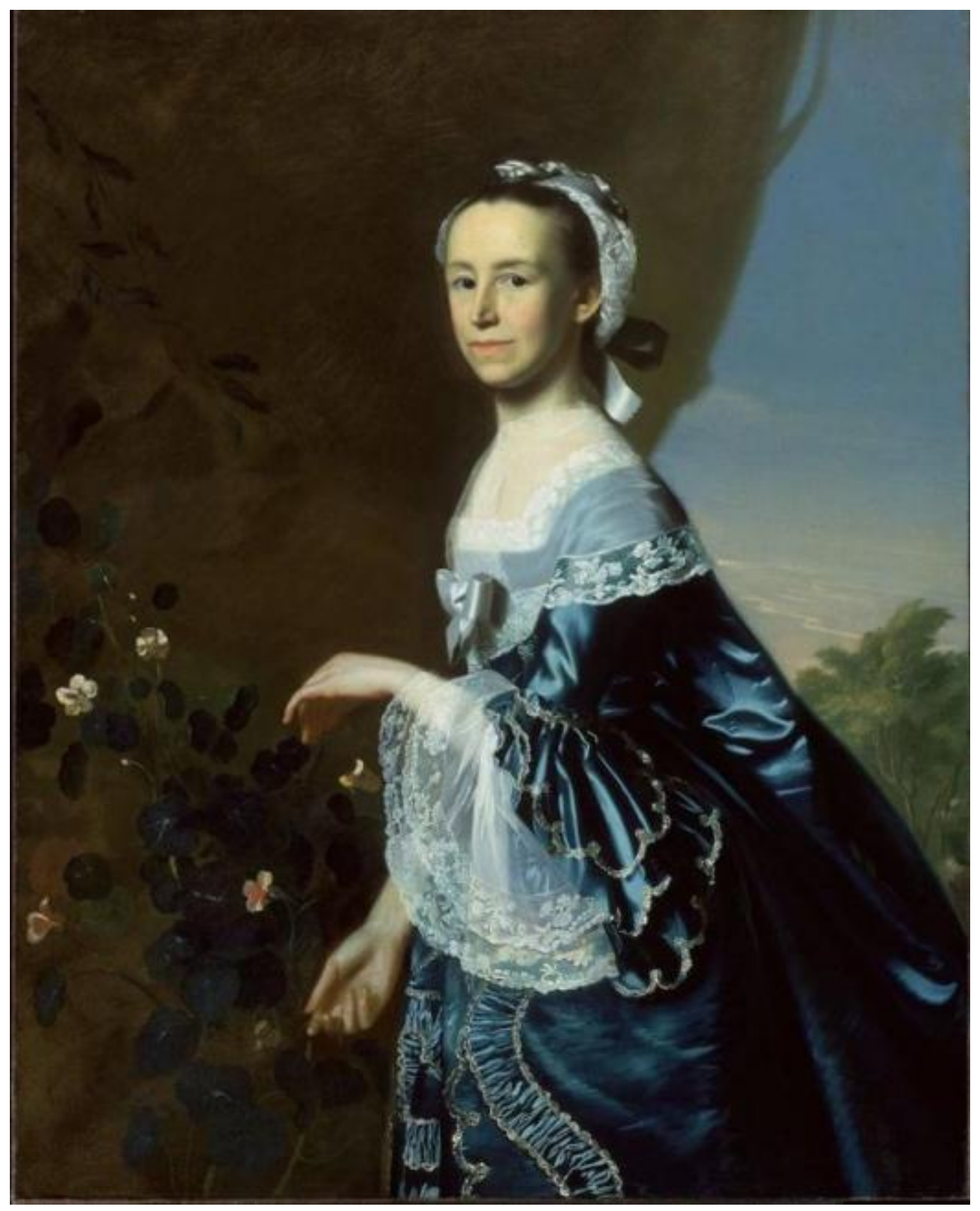

Figure 35. John Singleton Copley, Mercy Otis Warren, 1779. Oil on Canvas, 1763, 50 x 39.76 in., Boston Museum of Fine Arts, Boston. 


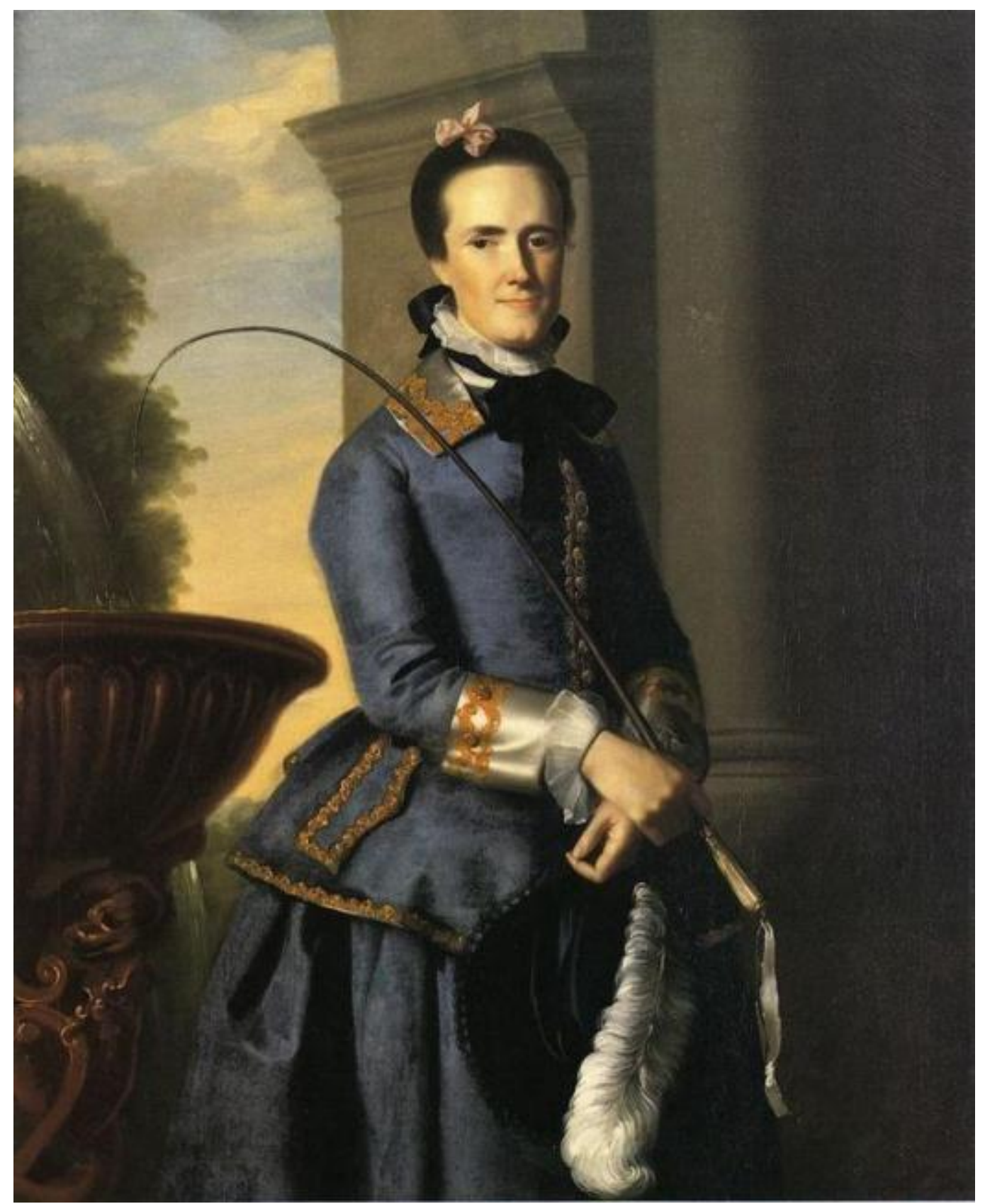

Figure 36. John Singleton Copley, Catherine Sargent, 1764. Oil on Canvas, 38.98 x 48.82 in., Private Collection. 


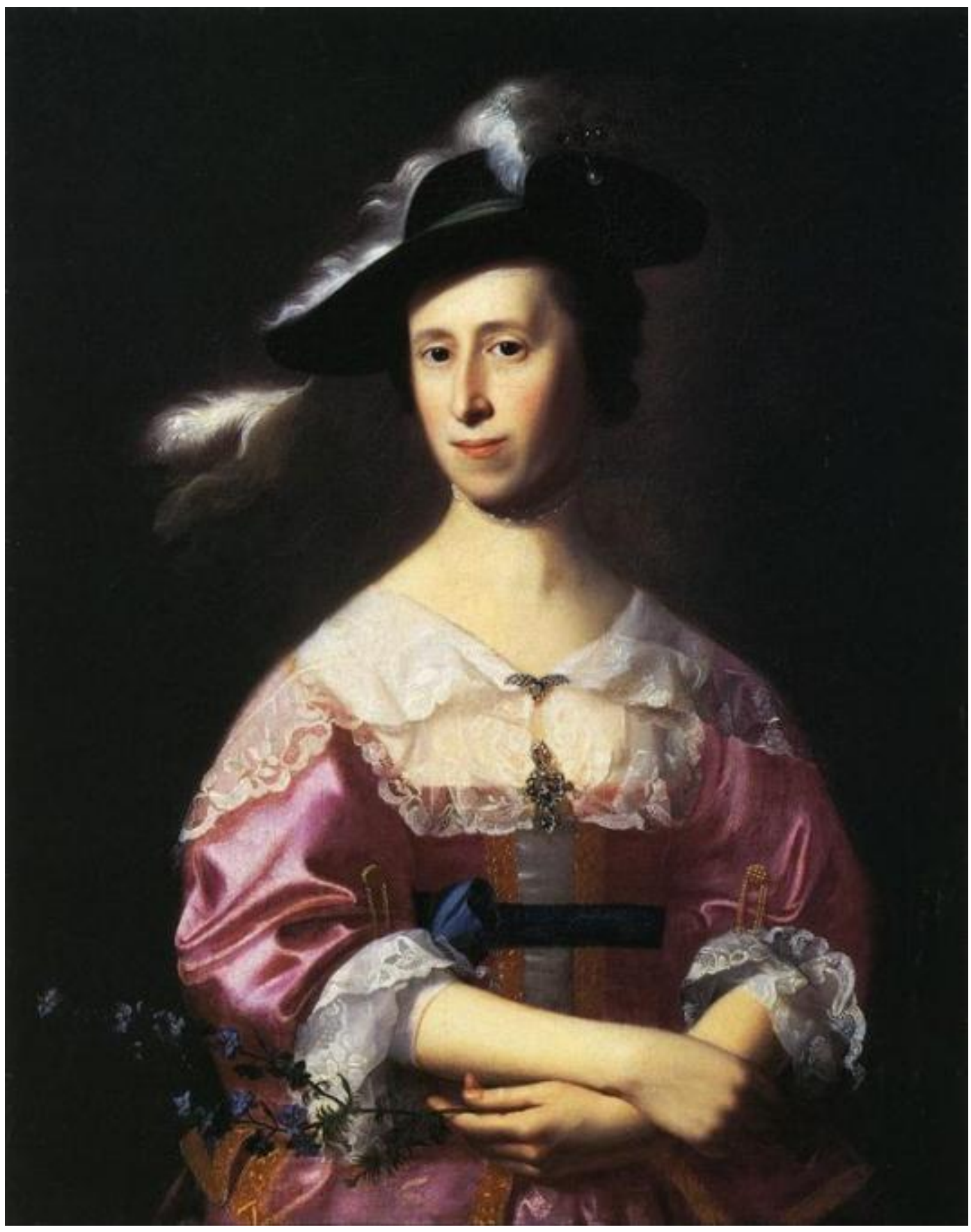

Figure 37. John Singleton Copley, Hannah Hill Quincy (Mrs. Samuel Quincy), 1761. Oil on canvas, 28 1/4 x 30 1⁄2 in., Museum of Fine Arts, Boston. 


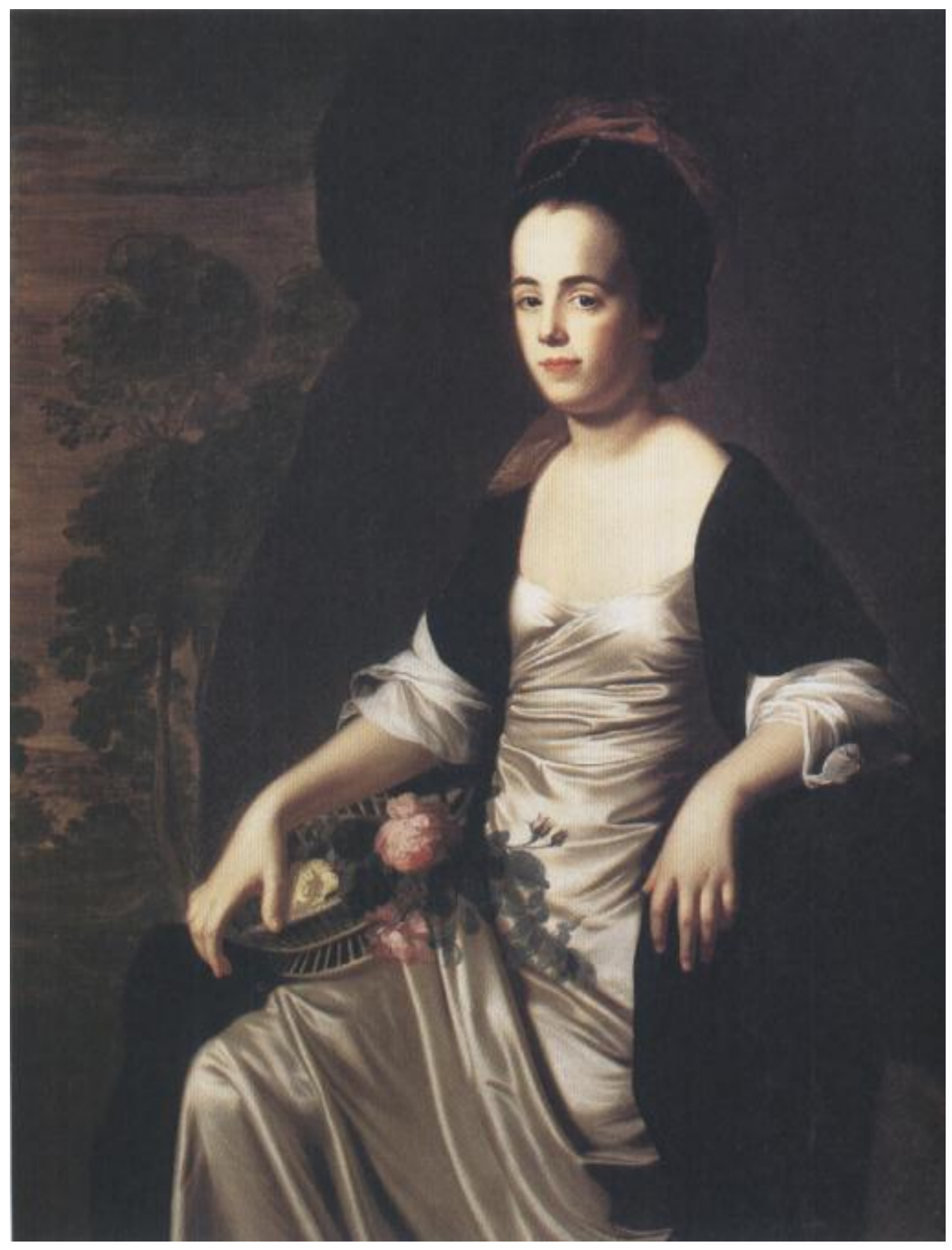

Figure 38. John Singleton Copley, Judith Sargent (Mrs. John Stevens, later Mrs. John Murray), 1770-1771. Oil on Canvas, 50 x 40 in., Terra Foundation for American Art, Chicago. 


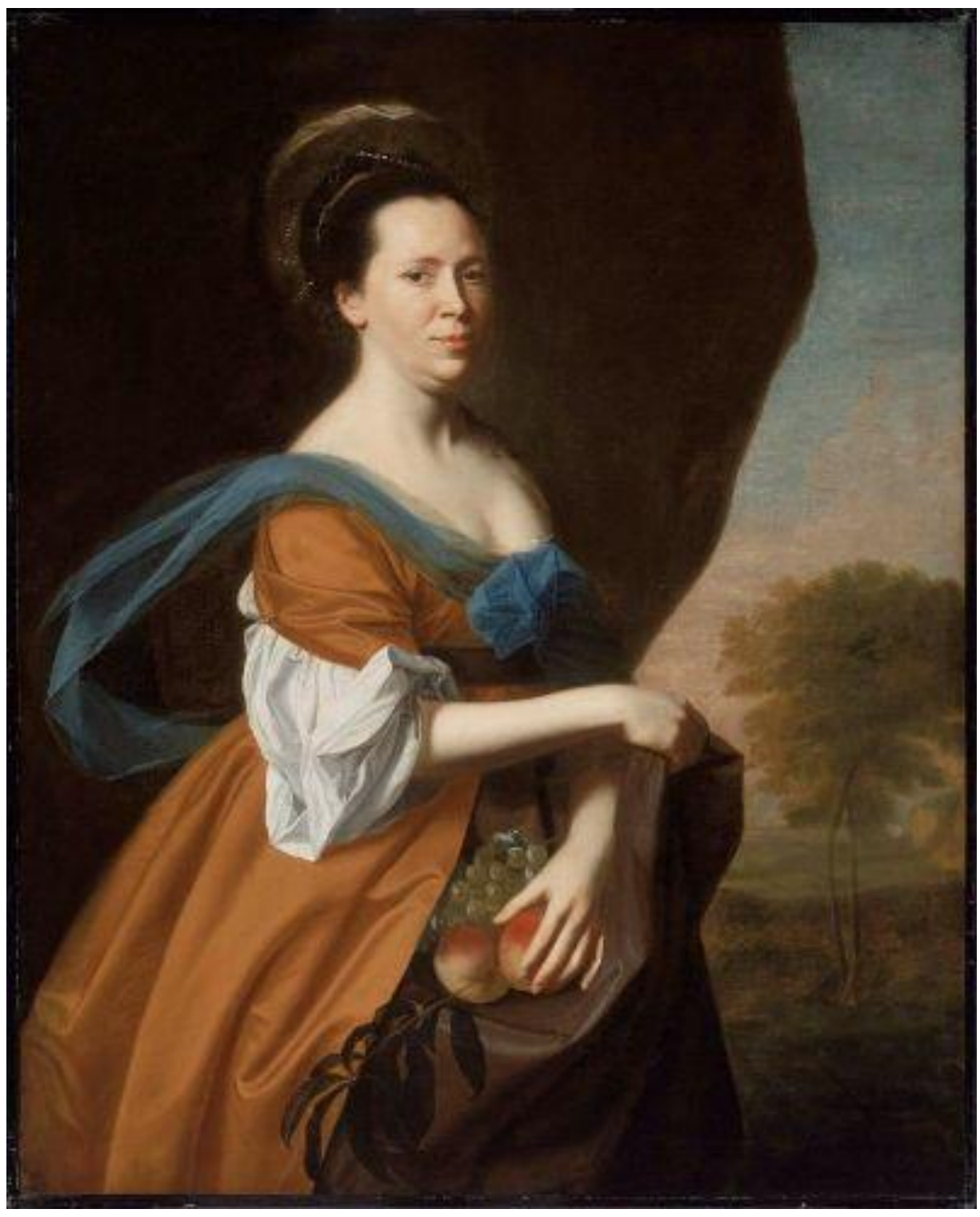

Figure 39. John Sngleton Copley, Elizabeth Murray Smith (Mrs. James Smith, later Mrs. John Inman), 1769. Oil on canvas, 49 5/8 x 40 in., Museum of Fine Arts, Boston. 


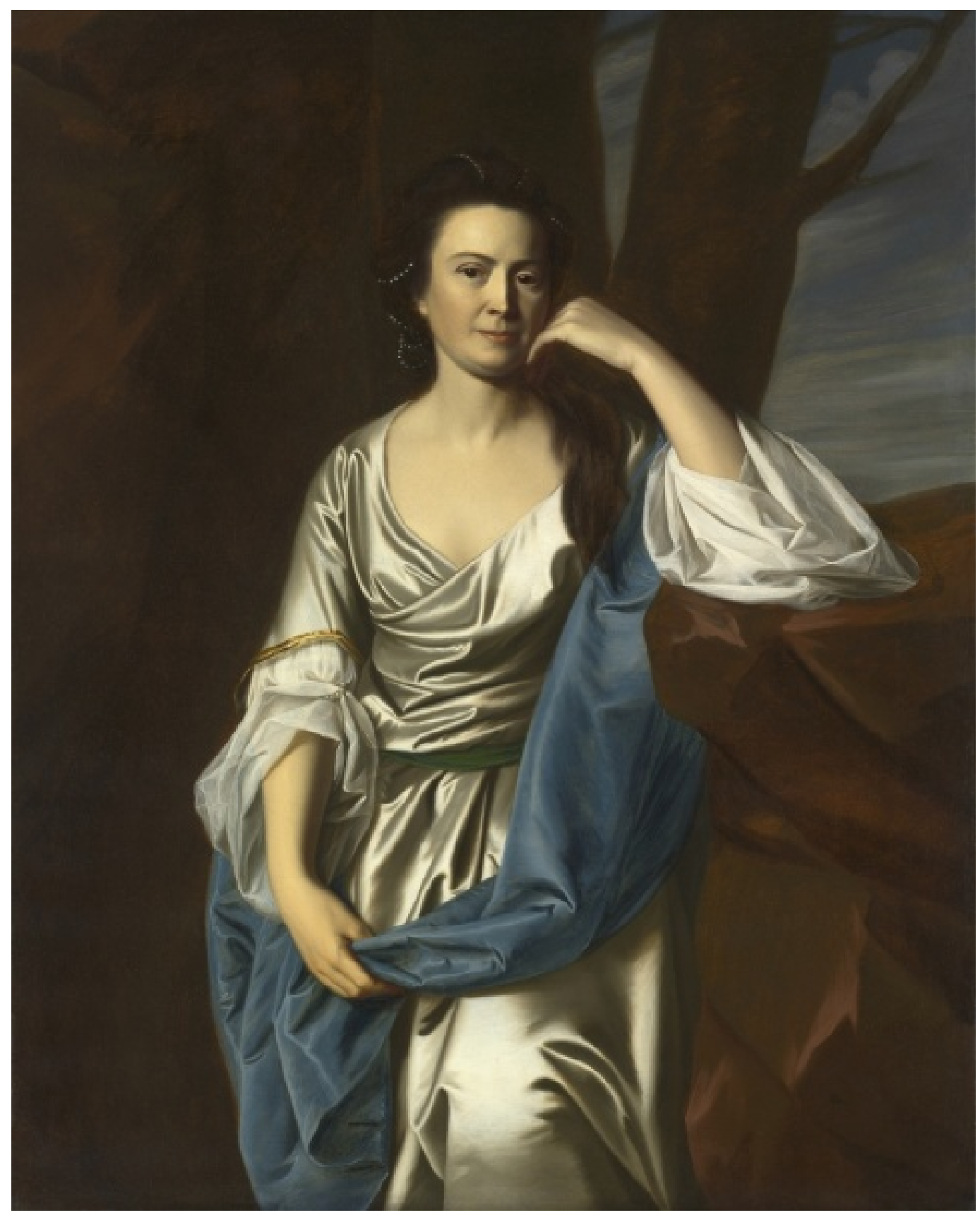

Figure 40. John Singleton Copley, Catherine Greene (Mrs. John Greene), 1769. Oil on canvas, 49 7/16 x 9 3/4 in., Cleveland Museum of Art. 


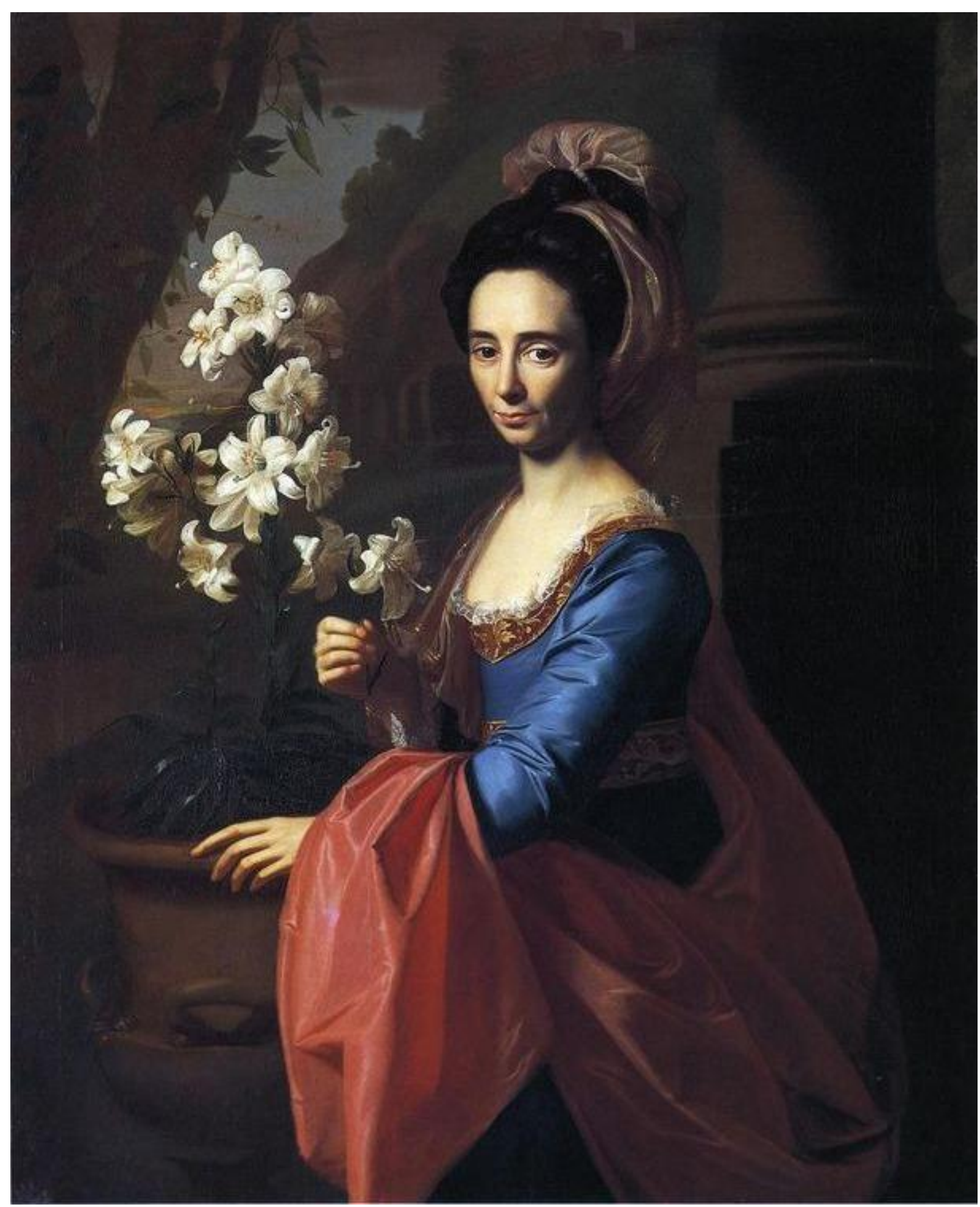

Figure 41. John Singleton Copley, Rebecca Boylston Gill (Mrs. Moses Gill), 1773. Oil on Canvas, 49 3/4 x 39 1/2 in., Rhode Island School of Design Museum of Art. 


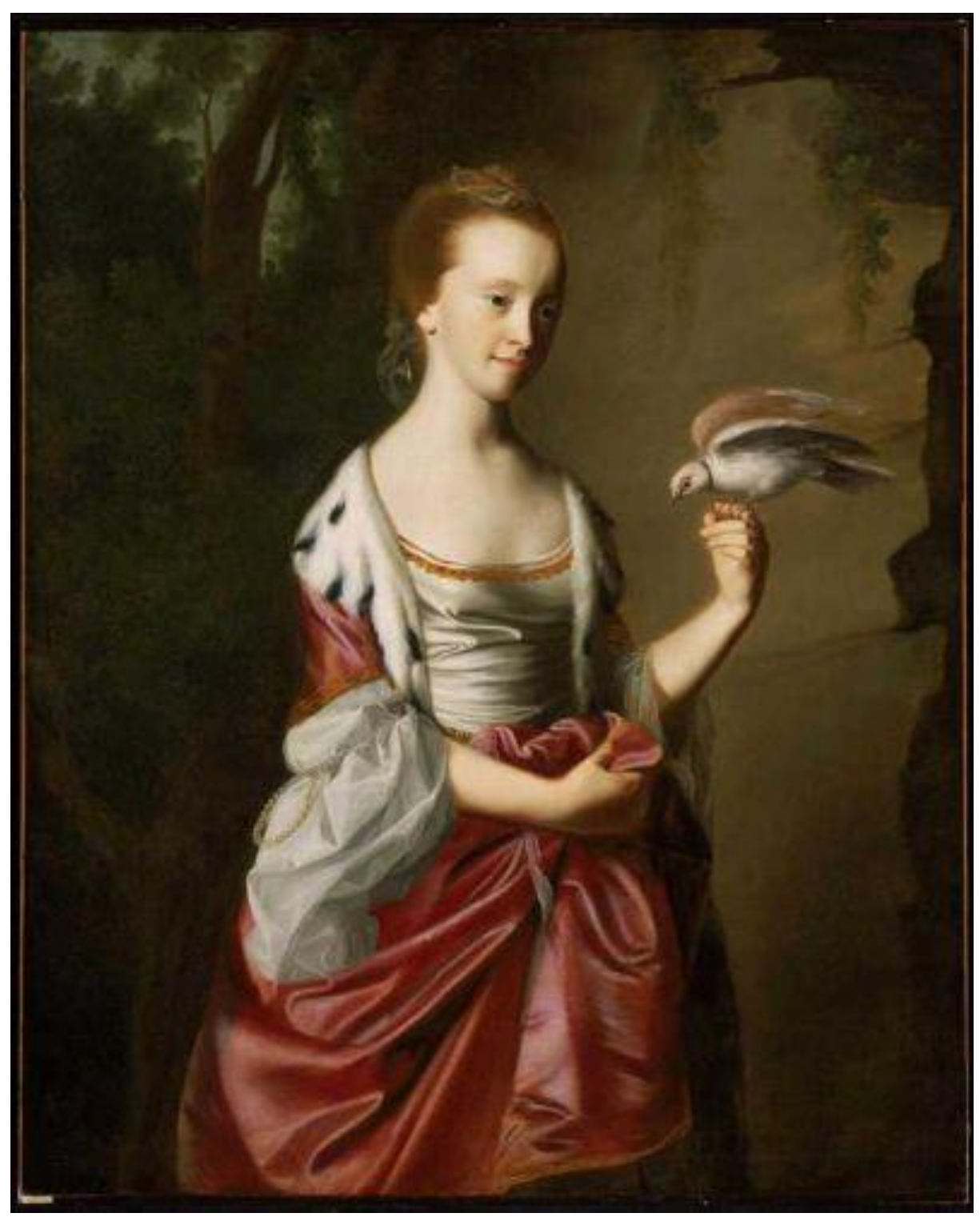

Figure 42. John Singleton Copley, Elizabeth Ross (later Mrs. William Tyng), 1766. Oil on canvas, 50 x 40 in., Museum of Fine Arts, Boston. 


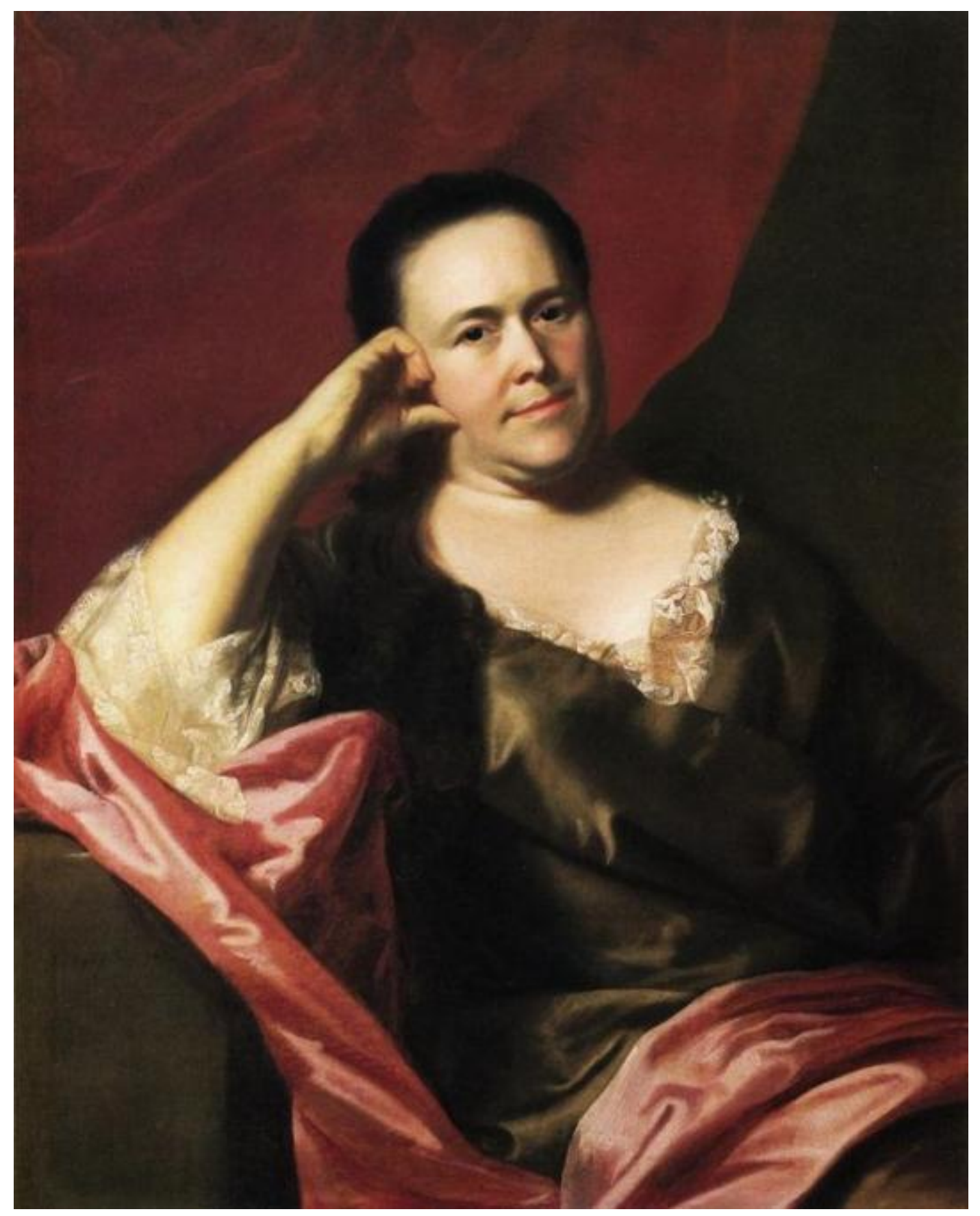

Figure 43. John Singleton Copley, Mercy Greenleaf Scoally (Mrs. John Scoally), 1763. Oil on canvas, 27 x 35 in., Baltimore Museum of Art. 


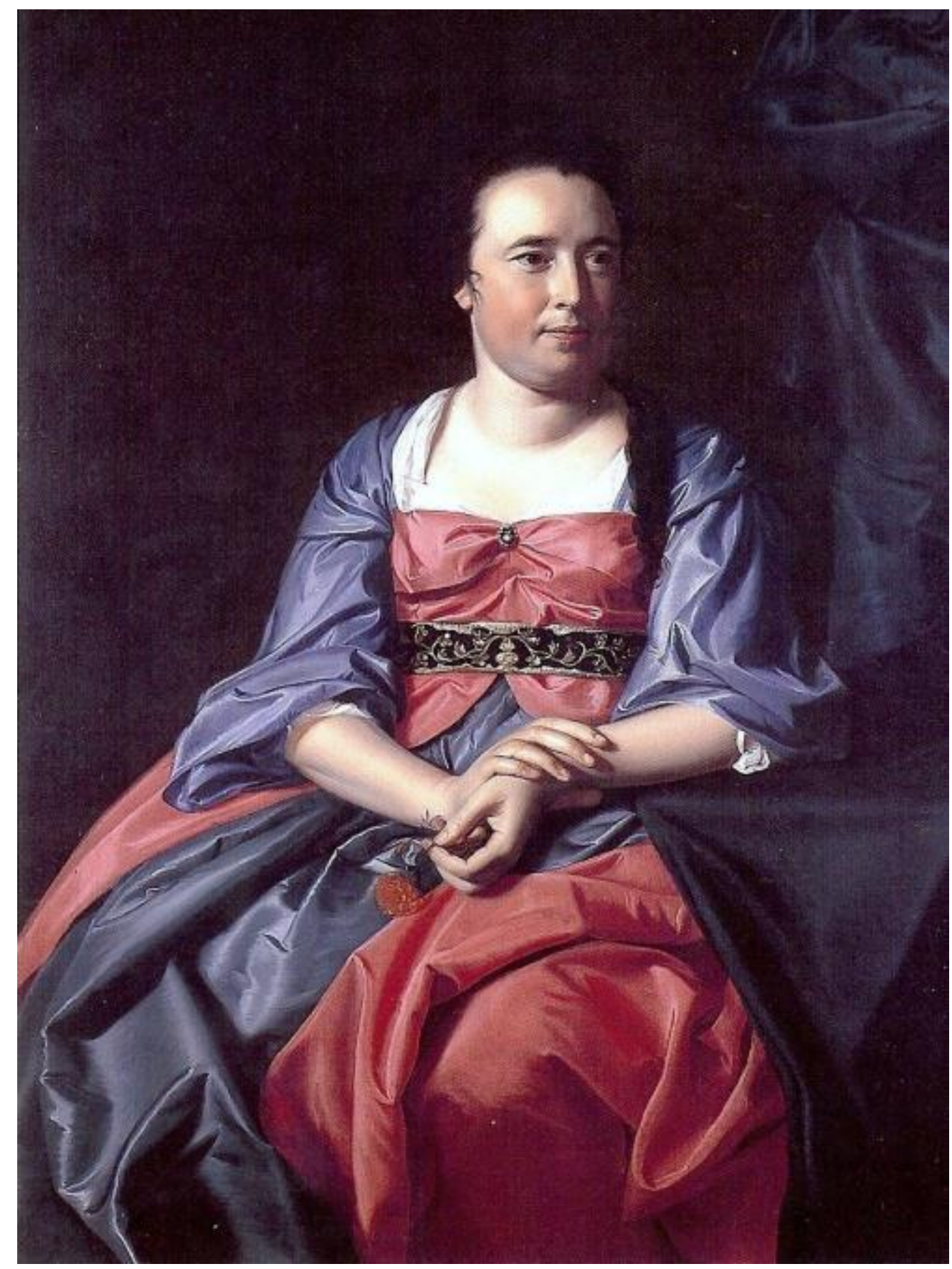

Figure 44. John Singleton Copley, Mary Harris Hooper (Mrs. Joseph Hooper), 1771, Oil on canvas, 50 x 40 in., Baltimore Museum of Art. 


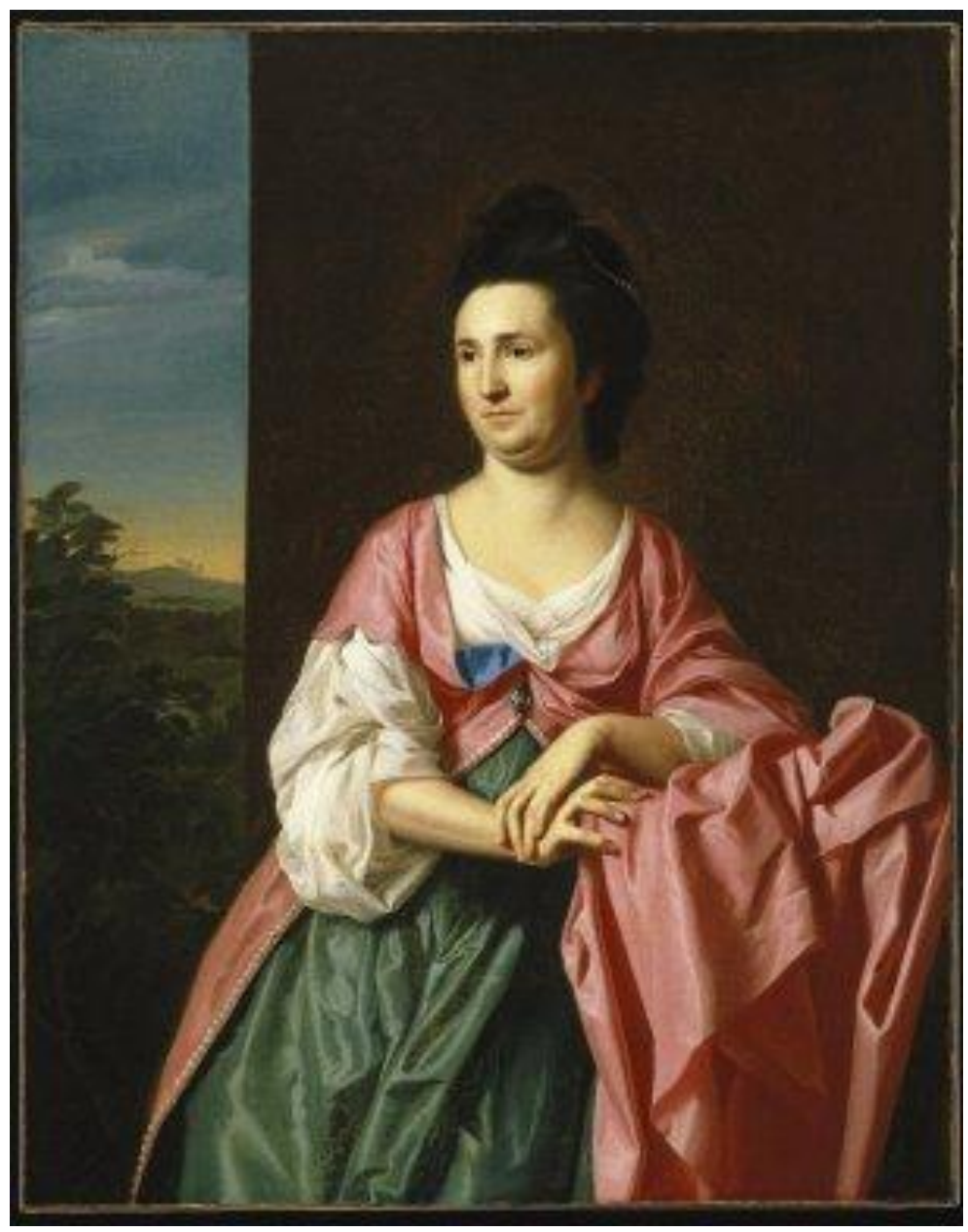

Figure 45. John Singleton Copley, Abigail Pickman Gardiner (Mrs. Sylvester Gardiner), 1772. Oil on canvas, 50 3/8 x 40 in., Brooklyn Museum of Art. 


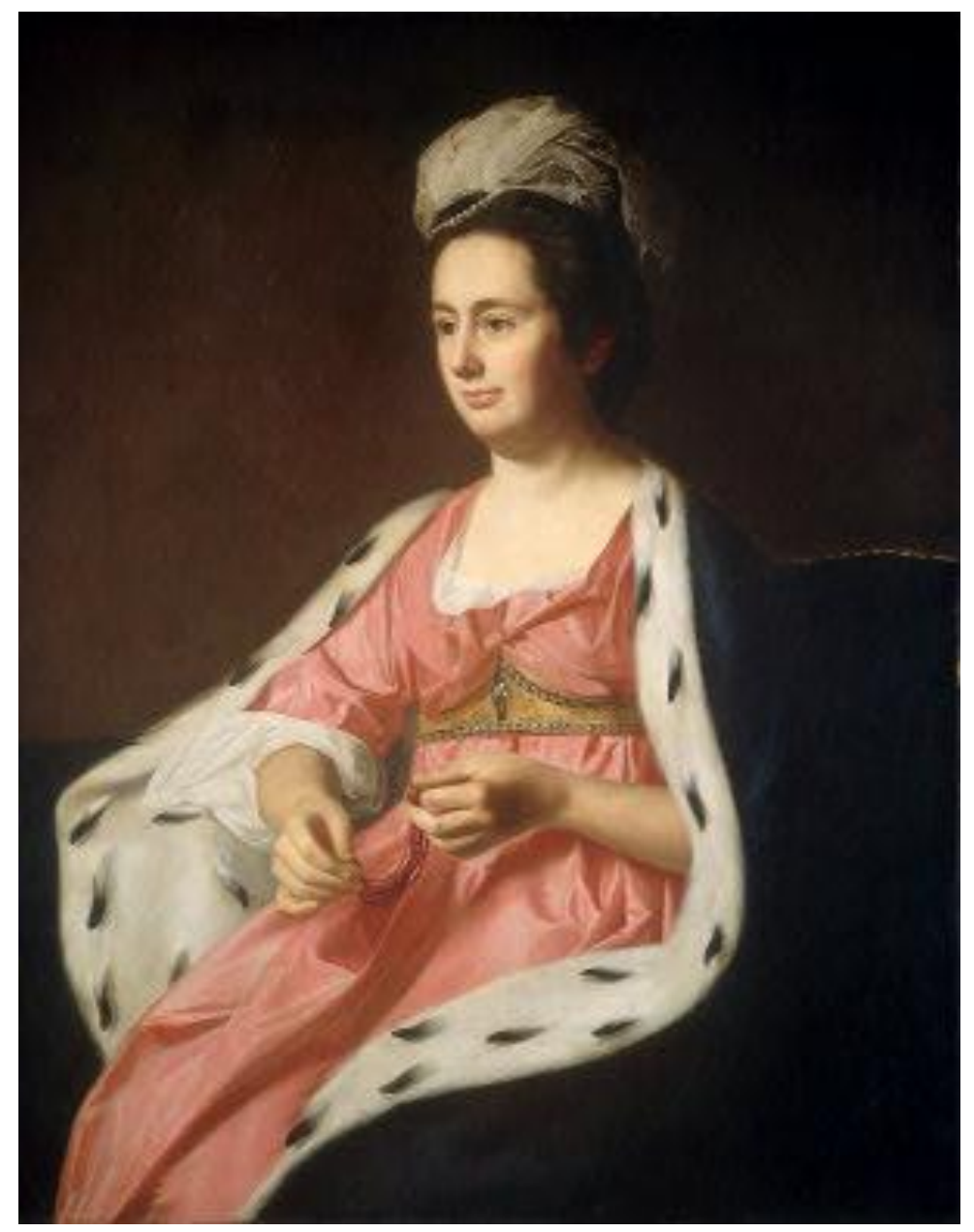

Figure 46. John Singleton Copley, Abigail Smith Babcock (Mrs. Adam Babcock), 1774. Oil on canvas, 46 x 35 3/4 in., National Gallery of Art, Washington, D.C. 


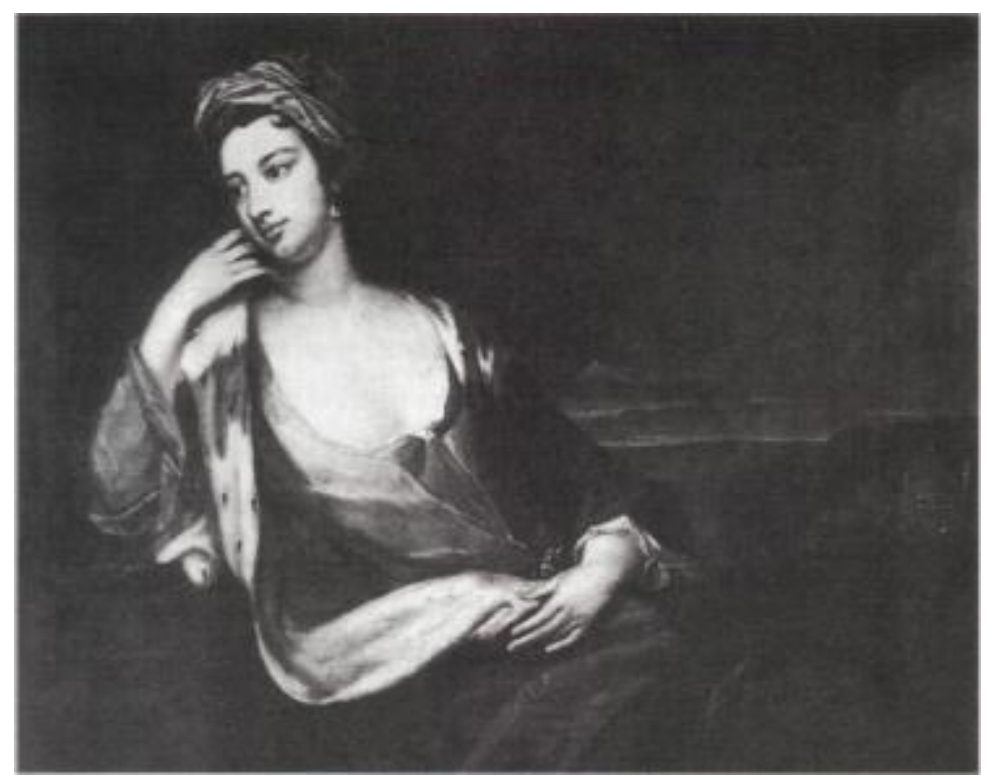

Figure 47. Caroline Watson after Sir Godfrey Kneller, Lady Mary Wortley Montagu, 1719-20. Engraving, The Marquess of Bute, Rothesay. 


\section{Works Cited}

Adams, Abigail, John Adams, L. H. Butterfield, Marc Friedlaender, and Mary Kline. The Book of Abigail and John: Selected Letters of the Adams family, 1762-1784. Cambridge, Mass.: Harvard University Press, 1975.

Addison, Joseph. "The Rugged Thorn Shall Bear the Fragrant Rose." The Spectator 6 (1776): 90.

Alden, John Richard. General Gage in America: Being Principally a History of His Role in the American Revolution. New York: Greenwood Press, 1969.

Anderson, Virginia DeJohn. Creatures of Empire: How Domestic Animals Transformed Early America. Oxford: Oxford University Press, 2004.

Anker, Roy M.. Self-help and Popular Religion in Modern American Culture: An Interpretive Guide. Westport, Conn.: Greenwood Press, 1999.

Armstrong, Walter. Sir Joshua Reynolds: First President of the Royal Academy. New York: Scribner, 1905.

Barratt, Carrie Rebora. John Singleton Copley in America. New York: Metropolitan Museum of Art: 1995.

Barratt, Rebora Carrie. Turkish fashion in 18th-century America John Singleton Copley and Margaret Kemble Gage ; this catalogue accompanies the exhibition of the same name, at the Timken Museum of Art, December 11, 1998 - April 11, 1999. San Diego: Putnam Foundation, 1998.

Baumgarten, Linda. What Clothes Reveal: The Language of Clothing in Colonial and Federal America : the Colonial Williamsburg Collection. Williamsburg, Va.: Colonial Williamsburg Foundation in association with Yale University Press, New Haven, 2002.

Bloch, Ruth . "American Feminine Ideals in Transition: The Rise of the Moral Mother." Feminist Studies 4, no. 2 (1978): 101-126.

Bogden, Janet. "Care or Cure? Childbirth Practices in Ninteenth-Century America." Feminist Studies 4, no. 2 (1978): 92-99.

Boime, Albert. "Blacks in Shark-Infested Waters: Visual Encodings of Racism in Copley and Homer." Smithsonian Studies in American Art 3, Winter (1989): 19-47. 
Boston Museum of Fine Arts. "Mrs. Ezekiel Goldthwait." Boston Museum of Fine Arts. $\mathrm{mfa}$. org/collections/search_art.asp?recview=true\&id=32756\&coll_keywords=Elizabeth+ Goldthwait \&coll_accession $=\&$ coll_name $=\&$ coll_artist $=\&$ coll $\_p l a c e=\&$ coll_medium $=\&$ coll_culture $=\&$ coll_classification $=\&$ coll_credit $=\&$ coll_provenance $=\&$ coll_location $=\& c$ oll_has_images=\&c (accessed May 1, 2010).

Boydston, Jeanne. Home and Work: Housework, Wages, and the Ideology of Labor in the Early Republic. New York: Oxford University Press, 1990.

Breen, T.H.. "An Empire of Goods: The Anglicization of Colonial America, 1690-1776." The Journal of British Studies 25, October (1986): 467-499.

---. "Baubles of Britain: The American and Consumer Revolutions of the Eighteenth Century." Past and Present 119, May (1988): 73-104.

Breskin, Isabel . "On the Periphery of a Greater World: John Singleton Copley's 'Turquerie' Portraits." Winterthur Portfolio 36, no. 2/3 (2001): 97-123.

Burroughs, Louise . "John Singleton Copley." The Metropolitan Museum of Art Bulletin 12, December (1936): 220-256.

Bushman, Claudia, and Richard Bushman. "The Early History of Cleanliness in America." Journal of American History 74, no. 4 (1988): 1213-1238.

Carr, Lois G., and Lorena S. Walsh. "The Planter's Wife: The Experience of White Women in Seventeenth-Century Maryland." The William and Mary Quarterly 34, October (1977): 542-571.

Copley, John Singleton, and Henry Pelham. Letters \& Papers of John Singleton Copley and Henry Pelham: 1739 - 1776.. Boston: Massachusetts Historical Society, 1914.

Cox, Ian. The Scallop: Studies of a Shell and Its Influence on Humankind. London: "Shell" Transport and Trading Co., 1957.

Craven, Wayne. Colonial American Portraiture: The Economic, Religious, Social, Cultural, Philosophical, Scientific, and Aesthetic Foundations. Cambridge: Cambridge University Press, 1986.

Dance, S. Peter. Shell Collecting: An Illustrated History. Berkeley: University of California Press, 1966.

Davidson, Cathy N.. Revolution and the Word: The Rise of the Novel in America. New York: Oxford University Press, 1986. 
Davis, Kenneth C.. America's Hidden History: Untold Tales of the First Pilgrims, Fighting Women, and Forgotten Founders Who Shaped a Nation. New York: Smithsonian Books, 2008.

de Piles, Roger. "The Priniples of Painting." In Art in theory 1648-1815: an anthology of changing ideas, 308-313. Oxford, UK: Blackwell Publishers, 2000.

Delke, Emilia. French Painters in the Eighteenth Century. London: George Bell And Sons, 1899.

Desai, Anita. "Introduction." In Turkish Embassy Letters, i-xxvii. London: Pickering \& Chatto, 1993.

Earle, Alice Morse. Home Life in colonial days . Stockbridge, MA: Berkshire House, 1993.

Eddis, William. Letters from America. Cambridge: Belknap Press of Harvard University Press, 1969.

Elisseeff, Vadime. The Silk Roads: Highways of Culture and Commerce. New York: Berghahn Books, 2000.

Fischer, David Hackett. Paul Revere's Ride. New York: Oxford University Press, 1994.

Foote, Henry W.. "When Was John Singleton Copley Born." The New England Quarterly 10, no. 1 (1973): 111-120.

Fordyce, James. Sermons to Young Women. Philadelphia : M. Carey, 1767.

Gardener, Albert Eyck. "A Copley Primitive." Metropolitan Museum of Art Bulletin 20, April (1962): 257-263.

Goodman, Dena, and Kathryn Norberg. Furnishing the Eighteenth Century: What Furniture Can Tell Us About the European and American Past. New York: Routledge, 2007.

Greene, Jeffrey P.. American Furniture of the 18th Century. Newtown, CT: Taunton Press, 2001.

Gregory, John. A Fathers Legacy to His Daughters. Paris: F. Louis, 1819.

Hayes, Kevin J.. A Colonial Woman's Bookshelf . Knoxville: University of Tennessee Press, 1996.

Henry Luce III Center for the Study of American Culture, The. "Mrs. Charles Jeffery Smith (Elizabeth Woolsey Smith, 1736-1816)." The New York Historical Society. http://emuseum.nyhistory.org/code/emuseum.asp?style=Browse\&currentrecord=1\&page $=$ search \&profile=objects\&searchdesc $=$ Ralph\%20Earl\&quicksearch=Ralph\%20Earl\&ne wvalues=1\&newstyle=single \&newcurrentrecord=3 (accessed June 3, 2010). 
Hilles, Frederick Whiley, and Joshua Reynolds. Letters of Sir Joshua Reynolds, Cambridge: Cambridge University Press, 1929.

Jensen, Merrill. The Founding of a Nation: A History of the American Revolution, 1763-1776. New York: Oxford University Press, 1968.

Kerber, Linda K.. Women of the Republic: Intellect and Ideology in Revolutionary America. Chapel Hill: Published for the Institute of Early American History and Culture by the University of North Carolina Press, 1980.

Kruh, David. Always Something Doing: Boston's Infamous Scoally Square. Chicago: Northeastern University Press, 1989.

Lovell, Margaretta M.. Art in a season of revolution: painters, artisans, and patrons in early America. Philadelphia: University of Pennsylvania Press, 2007.

---. "Copley and the Case of the Blue Dress." The Yale Journal of Criticism 11, no. 1 (1998): 5367.

Lowe, Lisa. Critical Terrains: French and British Orientalisms. Ithaca: Cornell University Press, 1991.

Marly, Diana. Dress in North America. New York: Holmes \& Meier, 1990.

Mays, Dorothy A.. Women in Early America: Struggle, Survival, and Freedom in a New World. Santa Barbara: ABC-CLIO, 2004.

Miles, Ellen Gross. The Portrait in Eighteenth-Century America. Newark: University of Delaware Press ;, 1993.

Montagu, Mary Wortley, and James Archibald Stuart Wharncliffe. The Letters and Works of Mary Wortley Montagu. London: George Bell And Sons, 1871.

More, Hannah. The Works of Hannah More. New York: Harper \& Brothers, 1793.

Murray, Christopher John. Encyclopedia of the Romantic Era, 1760-1850 . New York: Fitzroy Dearborn, 2004.

Nivelon, Francois. The Rudiments of Genteel Behavior. London: Paul Holberton Publishing, 1737.

Norton, Mary Beth. Founding Mothers \& Fathers: Gendered Power and the Forming of American Society. New York: A.A. Knopf, 2002.

---. Liberty's Daughters: The Revolutionary Experience of American Women, 1750-1800.

Boston: Little, Brown, 1980. 
Novak, Barbara. American Painting of the Nineteenth Century: Realism, Idealism, and The American Experience. New York: Praeger, 1979.

Park, Lawrence. Joseph Blackburn, a Colonial Portrait Painter;. Worcester, Mass.: The Massachusetts Historical Society, 1923.

Parker, Barbara Neville, and Anne Bolling Wheeler. John Singleton Copley: American Portraits in Oil, Pastel, and Miniature, . Boston: Museum of Fine Arts, 1938.

Pastoureau, Michel. Blue: The History of a Color. Princeton: Princeton University Press, 2001.

Piper, David. The English Face. London: Thames and Hudson, 1957.

Pointon, Marcia R.. Hanging the Head: Portraiture and Social Formation in EighteenthCentury England. New Haven: Published for the Paul Mellon Centre for Studies in British Art by Yale University Press, 1993.

Pratt, Mary Louise. "Arts of the Contact Zone." Profession 91 (1991): 33-40.

Prown, Jules D.. "Anatomy Book by John Singleton Copley." The Art Quarterly 24, Spring (1963): 20-25.

---. Art as evidence: writings on art and material culture. New Haven, CT: Yale University Press, 2001.

---. John Singleton Copley. Cambridge, Mass.: Harvard Univ. Press, 1966.

Radden, Jennifer. The Nature of Melancholy: From Aristotle to Kristeva. Oxford: Oxford University Press, 2000.

Rebora, Carrie. "Faces of a New Nation: American Portraits of the Late Eighteenth and Early Ninteenth Centuries." The Metropolitan Museum of Art Bulletin 61, Summer (2003): 359.

---. "Transforming Colonists into Goddesses and Sultans: John Singleton Copley, His Clients, and Their Studio Collaboration." American Art Journal 1-2 (1995): 1-25.

Reilly, Richard. "Margaret 200 Years Later." San Diego Union-Tribune, July 1, 1984.

Reitzes, Lisa B.. "Faces of a New Nation." In A National Image: the American Paintings and Sculpture Collection in the San Antonio Museum of Art, 19-21. Austin: University of Texas Press, 2003.

Reynolds, Joshua, Henry William Beechey, Thomas Gray, and Charles Dufresnoy. The Literary Works of Sir Joshua Reynolds. London: Henry G. Bohn, 1852. 
Ribeiro, Aileen. The Art of Dress: Fashion in England and France 1750 to 1820. New Haven: Yale University Press, 1995.

--- Dress in Eighteenth-century Europe, 1715-1789. New Haven: Yale University Press, 2002.

Richardson, Edgar Preston. American Paintings and Related Pictures in the Henry Francis du Pont Winterthur Museum. Charlottesville: Published for the Henry Francis du Pont Winterthur Museum by the University Press of Virginia, 1986.

---. "Copley's New York Portraits." Winterthur Portfolio 2 (1965): 1-13.

Roark, Elisabeth Louise. Artists of Colonial America. Westport, Conn.: Greenwood Press, 2003.

Said, Edward W.. Orientalism. New York: Pantheon Books, 1979.

Saunders, Richard H., and John Smibert. John Smibert: Colonial America's First Portrait Painter. New Haven: Yale University Press, 1995.

Scarce, Jennifer M.. Women's Costume of the Near and Middle East. London: Unwin Hyman, 1987.

Sime, John. Sir Joshua Reynolds. London: Methuen And Co., 1903.

Simon, Robin. The Portrait in Britain and America: With a Biographical Dictionary of Portrait Painters 1680-1914. Boston: G.K. Hall, 1987.

Simon, Robin. The Portrait in Britain and America. New York: MacMillian Publishing Company, 1987.

Staiti, Paul. "Accounting for Copley." In John Singleton Copley in America , 25-40. New York: Metropolitan Museum of Art :, 1995.

---. "Character and Class." In John Singleton Copley in America, 12-37. New York: Metropolitan Museum of Art, 1995.

Stark, James Henry. The Loyalists of Massachusetts and the Other Side of the American Revolution. Boston: J.H. Stark, 1910.

Stein, Perrin. "Amédée Van Loo's Costume Turc: The French Sultana." Art Bulletin 78, September (1996): 417-438.

The Artist's Repository and Drawing Magazine: Exhibiting the Principles of the Polite Arts in Their Various Branches. London: T. Williams, 1784.

Tomlins, Christopher L., and Bruce H. Mann. The Many Legalities of Early America. Chapel Hill: University of North Carolina Press, 2001. 
Turner, Bryan S.. Readings in Orientalism. London: Routledge, 2000.

Warren, Mercy Otis. Poems, Dramatic and Miscellaneous. Boston: I. Thomas and E.T. Andrews, 1790.

Warren, Mercy Otis, Jeffrey H. Richards, and Sharon M. Harris. Mercy Otis Warren: Selected Letters. Athens, GA: University of Georgia Press, 2009.

Wertkin, Gerard C., and Lee Kogan. Encyclopedia of American Folk Art. New York: Routledge, 2004.

Whitmore, William H.. "The Copleys and Pelhams of New England." Heraldic Journal IV (1868): 175-178.

Whitmore, William Henry. Notes Concerning Peter Pelham, The Earliest Artist Resident in New England, and His Successors Prior to the Revolution. Cambridge: Press of J. Wilson, 1867.

Williamson, Hugh . Letter from Sylvious to the Freeman Inhabitants of the United States: Containing Some Remarks on the Scarcity of Money; Paper Currency; National Dress; Foreign Luxuries; the Federal Debt; and Public Taxes. New York: Carroll and Patterson, 1787. 